\title{
Analysis of Fractures in Cores from the Tuff Confining Unit beneath Yucca Flat, Nevada Test Site
}

March 2008

Prepared for:

U.S. Department of Energy, National Nuclear Security Administration Nevada Site Office

Prepared by:

Lance B. Prothro

Environmental Restoration 


\section{DISCLAIMER STATEMENT}

Reference herein to any specific commercial product, process, or service by trade name, trademark, manufacturer, or otherwise, does not necessarily constitute or imply its endorsement, recommendation, or favoring by the U.S. Government or any agency thereof or its contractors or subcontractors.

\section{AVAILABILITY STATEMENT}

Available for sale to the public, in paper, from-

U.S. Department of Commerce

National Technical Information Service

5285 Port Royal Road

Springfield, VA 22161-0002

Telephone: 800.553.6847

Fax: 703.605.6900

E-mail: orders@ntis.gov

Online ordering: http://www.ntis.gov/ordering.htm

Available electronically at http://www.osti.gov/bridge.

Available for a processing fee to U.S. Department of Energy and its contractors, in paper, from-

U.S. Department of Energy

Office of Scientific and Technical Information

P.O. Box 62

Oak Ridge, TN 37831-0062

Telephone: 865.576.8401

Fax: 865.576.5728

E-mail: reports@adonis.osti.gov 
National Security Technologies LLC

DOE/NV/25946--351

Analysis of Fractures in Cores from the Tuff Confining Unit beneath Yucca Flat, Nevada Test Site

March 2008

Approved by:

Tame B.P roth

Lance B. Prothro, Senior Geologist

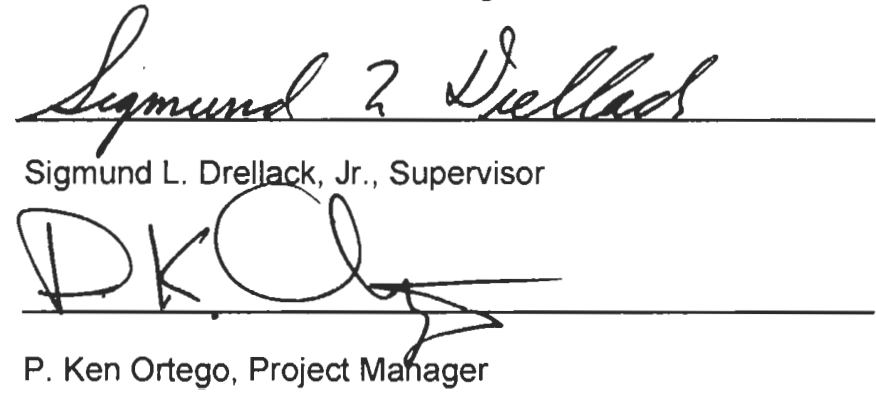

Date:

$04-23-2008$

$4-23-08$

$4 / 23 / 08$ 
This page intentionally left blank. 


\section{Abstract}

The role fractures play in the movement of groundwater through zeolitic tuffs that form the tuff confining unit (TCU) beneath Yucca Flat, Nevada Test Site, is poorly known. This is an important uncertainty, because beneath most of Yucca Flat the TCU lies between the sources of radionuclide contaminants produced by historic underground nuclear testing and the regional carbonate aquifer. To gain a better understanding of the role fractures play in the movement of groundwater and radionuclides through the TCU beneath Yucca Flat, a fracture analysis focusing on hydraulic properties was performed on conventional cores from four vertical exploratory holes in Area 7 of Yucca Flat that fully penetrate the TCU.

The results of this study indicate that the TCU is poorly fractured. Fracture density for all fractures is 0.27 fractures per vertical meter of core. For open fractures, or those observed to have some aperture, the density is only 0.06 fractures per vertical meter of core. Open fractures are characterized by apertures ranging from 0.1 to 10 millimeter, and averaging 1.1 millimeter. Aperture typically occurs as small isolated openings along the fracture, accounting for only 10 percent of the fracture volume, the rest being completely healed by secondary minerals. Zeolite is the most common secondary mineral occurring in 48 percent of the fractures observed. 
This page intentionally left blank. 


\section{Table of Contents}

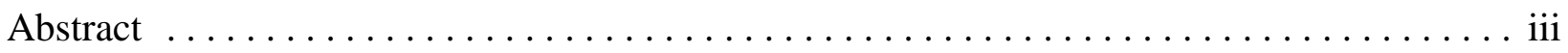

List of Figures $\ldots \ldots \ldots \ldots \ldots \ldots \ldots \ldots \ldots \ldots \ldots \ldots \ldots \ldots \ldots \ldots \ldots \ldots \ldots$

List of Tables $\ldots \ldots \ldots \ldots \ldots \ldots \ldots \ldots \ldots \ldots \ldots \ldots \ldots \ldots \ldots \ldots \ldots \ldots \ldots \ldots$

List of Acronyms and Abbreviations $\ldots \ldots \ldots \ldots \ldots \ldots \ldots \ldots \ldots \ldots \ldots \ldots$ ix

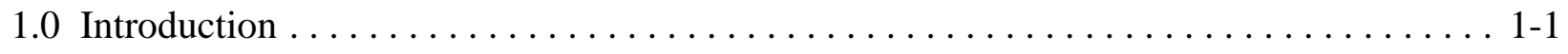

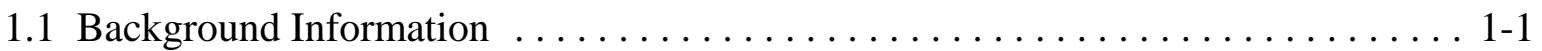

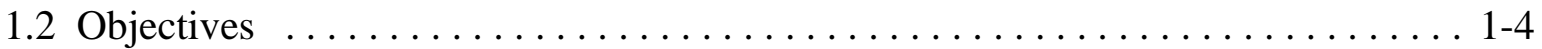

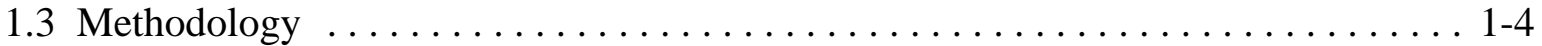

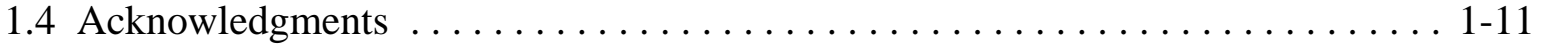

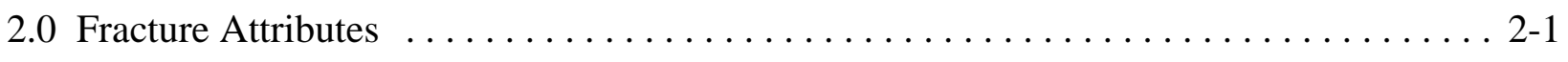

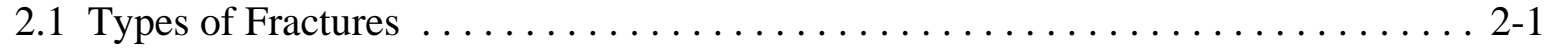

2.2 Fracture Shape and Orientation $\ldots \ldots \ldots \ldots \ldots \ldots \ldots \ldots \ldots \ldots \ldots \ldots \ldots \ldots \ldots \ldots \ldots$

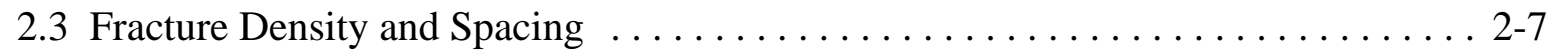

2.4 Fracture Width, Aperture, and Openness . . . . . . . . . . . . . . 2-16

2.5 Fracture Surface Texture . . . . . . . . . . . . . . . . . . . 2-19

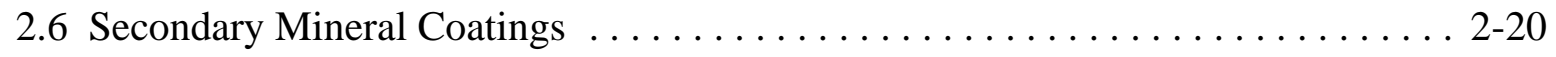

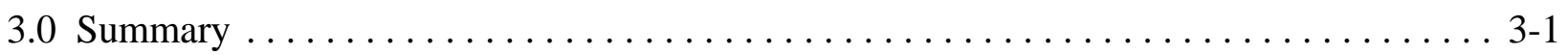

4.0 References Cited $\ldots \ldots \ldots \ldots \ldots \ldots \ldots \ldots \ldots \ldots \ldots \ldots \ldots \ldots \ldots \ldots \ldots \ldots \ldots \ldots$

Appendix A- List of Core Holes in Yucca Flat

Distribution List 
This page intentionally left blank. 


\section{List of Figures}

Number

Title

Page

1-1 Shaded Relief Map of Yucca Flat Showing Locations of Core Holes Analyzed

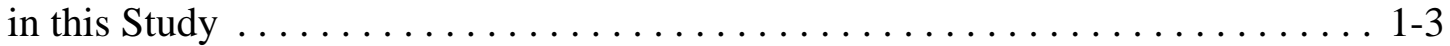

1-2 A Portion of UE-7f Core Laid Out for Fracture Analysis at the U.S. Geological Survey Geologic Data Center and Core Library in Mercury, Nevada . . . . . . . . . . 1-6

1-3 Coring-Induced Breaks $\ldots \ldots \ldots \ldots \ldots \ldots \ldots \ldots \ldots \ldots \ldots \ldots \ldots$

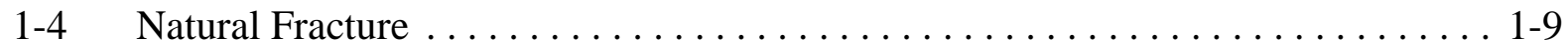

1-5 Natural Fracture with Well Developed Slickensides . . . . . . . . . . . . . 1-10

2-1 Natural Fracture Showing a Subtle Linear Texture on Fracture Surfaces ... . . . 2-3

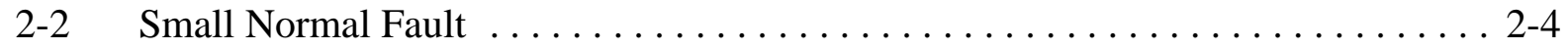

2-3 Natural Fracture with a Planar, Continuous Shape $\ldots \ldots \ldots \ldots \ldots \ldots \ldots . . .2$

2-4 Natural Fracture with an Irregular, Continuous Shape $\ldots \ldots \ldots \ldots \ldots \ldots . . .2$. . . .

$2-5$ Vertical Distribution of Fractures within the TCU in UE-7f $\ldots \ldots \ldots \ldots \ldots .2-8$

2-6 Vertical Distribution of Fractures within the TCU in UE-7az . . . . . . . . . . 2-9

2-7 Vertical Distribution of Fractures within the TCU in UE-7ba $\ldots . \ldots \ldots \ldots$. . .

$2-8$ Vertical Distribution of Fractures within the TCU in UE-7bc $\ldots \ldots \ldots \ldots .2-11$

2-9 Argillic Tuff Showing Highly Broken Character $\ldots . \ldots \ldots \ldots \ldots \ldots \ldots \ldots$. . . . . . . .

2-10 Clay-Filled Fracture in Paleozoic-Age Limestone $\ldots . \ldots \ldots \ldots \ldots \ldots \ldots$. . . . . . . .

2-11 Alignment of Aperture Along Outer Surface of Core $\ldots \ldots \ldots \ldots \ldots \ldots \ldots$. . . . . .

2-12 Fracture with Large, Through-Going Aperture $\ldots \ldots \ldots \ldots \ldots \ldots \ldots \ldots$ 2-18

2-13 Fracture Filled with Quartz, Calcite, and Iron Oxide $\ldots \ldots \ldots \ldots \ldots \ldots \ldots$ 2-21

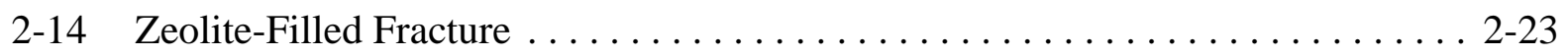

2-15 Joint Surface Coated with Manganese Oxide $\ldots \ldots \ldots \ldots \ldots \ldots \ldots \ldots$. . . . . . .

2-16 Joints Completely Filled with Crystalline Quartz . . . . . . . . . . . . . . 2-25 


\section{List of Tables}

Number

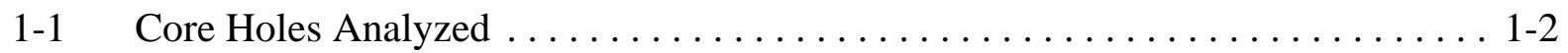

1-2 Definitions of Terms Used in this Report $\ldots \ldots \ldots \ldots \ldots \ldots \ldots \ldots \ldots \ldots$

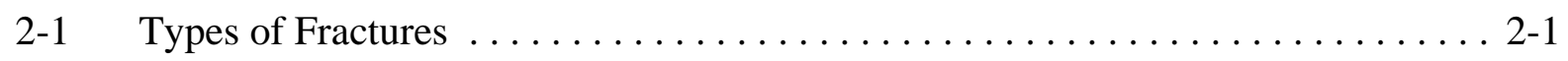

$2-2$ Shapes of Fractures $\ldots \ldots \ldots \ldots \ldots \ldots \ldots \ldots \ldots \ldots \ldots \ldots \ldots \ldots \ldots \ldots \ldots \ldots \ldots \ldots \ldots, 2$

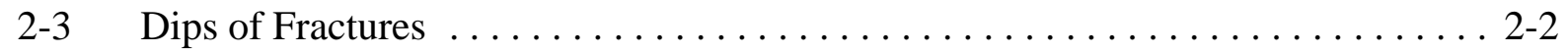

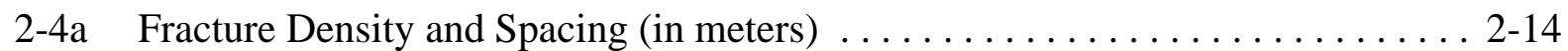

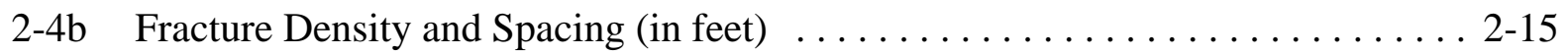

2-5 Fracture Width, Aperture, and Openness . . . . . . . . . . . . . . . . . 2-19

2-6 Secondary Minerals Observed Visually in Fractures $\ldots \ldots \ldots \ldots \ldots \ldots . . \ldots .22$ 


\section{List of Acronyms and Abbreviations}

$\begin{array}{ll}\text { BN } & \text { Bechtel Nevada } \\ \mathrm{cm} & \text { centimeter(s) } \\ \mathrm{ft} & \text { foot (feet) } \\ \mathrm{m} & \text { meter(s) } \\ \mathrm{mm} & \text { millimeter(s) } \\ \text { NSTec } & \text { National Security Technologies, LLC } \\ \text { TCU } & \text { tuff confining unit } \\ \text { TD } & \text { total depth } \\ \text { UGTA } & \text { Underground Test Areas Subproject }\end{array}$


This page intentionally left blank. 


\subsection{Introduction}

This report presents results of a study of fracture characteristics of the tuff confining unit (TCU) of Yucca Flat. This work was originally conducted in 1998 and was transmitted in a Bechtel Nevada (BN) informal report to a small internal distribution. This report has been updated to meet the publication format requirements of National Security Technologies, LLC (NSTec); no new data were obtained and the results, interpretations, and conclusions are unchanged from the original report.

This study was conducted for the U.S. Department of Energy, National Nuclear Security Administration Nevada Site Office Underground Test Area (UGTA) environmental restoration sub-project. It is part of the investigations associated with the development of groundwater flow and contaminant transport models of the Yucca Flat Corrective Action Unit at the Nevada Test Site.

\subsection{Background Information}

A thorough understanding of the movement of groundwater and radionuclides within the zeolitic tuffs that form the TCU beneath Yucca Flat is critical because most underground nuclear detonations in Yucca Flat were conducted within or above this important hydrogeologic unit. Beneath most of Yucca Flat the TCU separates the point sources of radionuclides (i.e., the working points of underground nuclear detonations) from the underlying regional carbonate aquifer, which is the most likely route for radionuclides in groundwater beneath Yucca Flat to exit the boundaries of the Nevada Test Site (Laczniak et al., 1996).

In the Yucca Flat-Climax Mine hydrostratigraphic framework model (BN, 2006), the TCU is divided into four hydrostratigraphic units: upper tuff confining unit, lower tuff confining unit, Oak Springs Butte confining unit, and argillic tuff confining unit. For more information on hydrogeologic and hydrostratigraphic units in and around Yucca Flat, as well as the geologic setting, see BN (2006).

The movement of groundwater within the TCU is believed to be controlled primarily by the interstitial permeability of the rocks (Winograd and Thordarson, 1975). Similarly, estimates by Winograd and Thordarson (1975) of leakage rates through the tuff aquitard (i.e., TCU) into the regional carbonate aquifer beneath Yucca Flat assume that water moves only through the matrix of zeolitic tuff, and not through fractures. However, the role fractures play in the downward 
leakage of water through the TCU in Yucca Flat is poorly known (Laczniak et al., 1996). This is mainly because the TCU beneath Yucca Flat is covered by younger volcanic rocks and thick valley-fill deposits, and is thus inaccessible for direct observation. Fortunately, numerous drill holes in Yucca Flat penetrate into the TCU, and many of these drill holes have conventional core (i.e., vertical rotary core samples) from the TCU available for analysis. However, no fracture analyses emphasizing hydraulic properties of fractures have previously been performed on these cores.

To gain a better understanding of the role fractures may play in the movement of groundwater and radionuclides through the TCU beneath Yucca Flat, a fracture analysis focusing on hydraulic properties was performed on conventional cores from four vertical, exploratory holes in Area 7 of Yucca Flat that fully penetrate the TCU (Figure 1-1). The holes selected for analysis are UE-7f, UE-7az, UE-7ba, and UE-7bc (Table 1-1).

Table 1-1

Core Holes Analyzed

\begin{tabular}{|c|c|c|c|c|c|c|c|}
\hline \multirow{2}{*}{ Hole } & \multicolumn{2}{|c|}{ Coordinates } & \multicolumn{2}{|c|}{ Surface Elevation } & \multicolumn{2}{|c|}{ Total Depth (TD) } & \multirow{2}{*}{$\begin{array}{l}\text { Date TD } \\
\text { Reached }\end{array}$} \\
\hline & meters & feet & meters & feet & meters & feet & \\
\hline UE-7f & $\begin{array}{l}\text { N 259,845.1 } \\
\text { E 207,114.8 }\end{array}$ & $\begin{array}{l}N 852,510 \\
\text { E 680,180 }\end{array}$ & $1,257.0$ & 4,124 & 860.8 & 2,824 & $10 / 21 / 1980$ \\
\hline UE-7az & $\begin{array}{l}\text { N 259,083.2 } \\
\text { E 210,558.4 }\end{array}$ & $\begin{array}{l}N 850,000 \\
E \quad 690,800\end{array}$ & $1,285.6$ & 4,218 & 744.0 & 2,441 & $07 / 22 / 1980$ \\
\hline UE-7ba & $\begin{array}{l}\text { N 259,465.6 } \\
\text { E 207,675.5 }\end{array}$ & $\begin{array}{l}\text { N 851,264 } \\
\text { E 681,350 }\end{array}$ & $1,258.8$ & 4,130 & 740.1 & 2,428 & $11 / 04 / 1979$ \\
\hline UE-7bc & $\begin{array}{l}\text { N } 258,470.4 \\
\text { E 211,273.0 }\end{array}$ & $\begin{array}{l}N 848,000 \\
E \text { 693,154 }\end{array}$ & $1,287.8$ & 4,225 & 825.1 & 2,707 & 09/05/1980 \\
\hline
\end{tabular}

Source: Raytheon Services Nevada, 1990.

This report summarizes results from the fracture analysis, providing information on fractures within a typical sequence of TCU beneath Yucca Flat. The information presented can be used to help better define parameters used in flow and transport models for the TCU beneath Yucca Flat, and also serves as a baseline for more detailed studies of the role fractures play in controlling movement of groundwater through the TCU. 

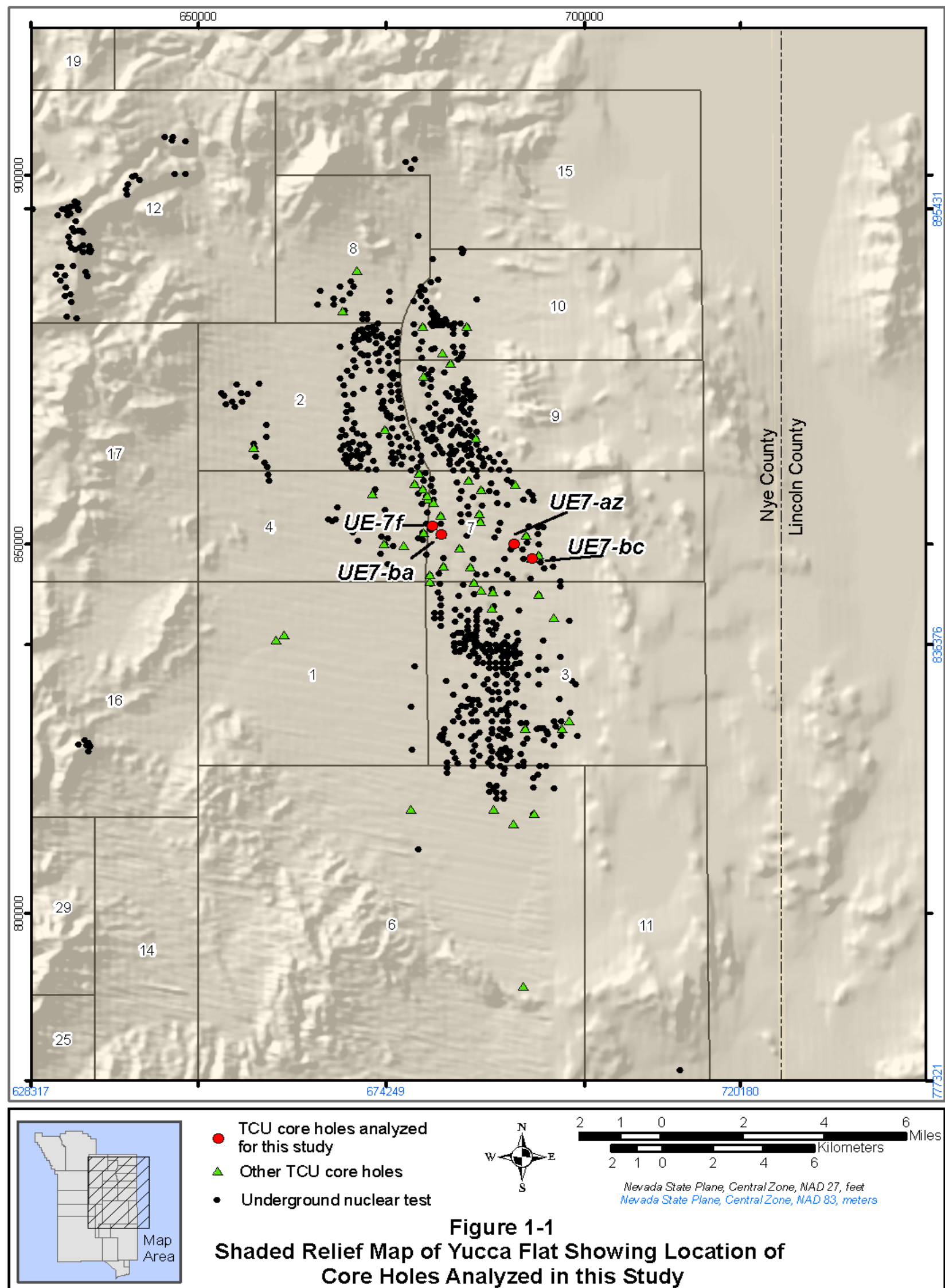

TCU core holes analyzed

for this study

$\triangle$ Other TCU core holes

- Underground nuclear test
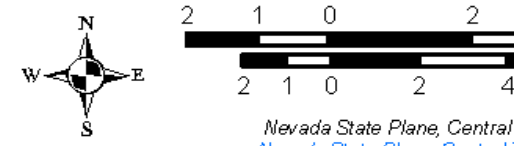

4

4

Kilometers

Nevada State Plane, CentralZone, MAD 27, feet

Figure 1-1

Shaded Relief Map of Yucca Flat Showing Location of Core Holes Analyzed in this Study 


\subsection{Objectives}

The objectives of this study were:

- Examine and analyze fractures in conventional cores from the TCU beneath Yucca Flat, emphasizing attributes that are important to groundwater flow and radionuclide migration.

- Quantify observations and develop basic statistical data on fracture attributes.

- Summarize results in a report for use by the developers of the UGTA groundwater-flow and radionuclide-migration models.

\subsection{Methodology}

The first step of the study was to search for suitable core holes for analysis. This involved gathering and tabulating a large amount of drilling and geologic information from all the drill holes in Yucca Flat that had been at least partially cored. Because of the size of this effort and the amount of data gathered, this information has been preserved as Appendix A of this report as a reference for future geologic and hydrogeologic studies in Yucca Flat.

Core holes UE-7f, UE-7az, UE-7ba, and UE-7bc were selected for the following reasons:

- All four holes were continuously cored through a complete section of TCU.

- $\quad$ The TCU is greater than 300 meters (m) (1,000 feet [ft]) thick in each hole.

- The diameter of the core in each hole is less than 10 centimeters (cm) (4 inches), making the handling and examination of the core safer and less time consuming, compared with larger diameter core.

The methods used to examine and analyze fractures generally followed those outlined in Drellack et al. (1997). Table 1-2, modified from Drellack et al. (1997), provides definitions of terms used in this report.

A total of 1,842.5 m (6,045 ft) of continuous conventional core was examined at the U.S. Geological Survey Geologic Data Center and Core Library in Mercury, Nevada (Figure 1-2). Approximately 90 percent of the core from each of the four holes was available for analysis; approximately 10 percent had been packaged at the rig-site for long-term moisture preservation, and thus was unavailable for examination. 


\section{Table 1-2 \\ Definitions of Terms Used in this Report \\ (Modified from Drellack et al., 1997)}

\begin{tabular}{|c|c|}
\hline Term & Definition Used in Study \\
\hline Fracture & A break or crack in a rock core. \\
\hline Natural Fracture & $\begin{array}{l}\text { A fracture resulting from natural geologic processes. Natural fractures are usually coated or } \\
\text { filled with secondary minerals. }\end{array}$ \\
\hline $\begin{array}{l}\text { Coring- and } \\
\text { Handling- } \\
\text { Induced Fracture }\end{array}$ & $\begin{array}{l}\text { A fracture resulting from stresses created during coring or handling. Coring- and handling- } \\
\text { induced fractures will not have secondary mineral coatings and have "fresh" appearance. }\end{array}$ \\
\hline Open Fracture & A natural fracture that has open space between the sides of the fracture. \\
\hline Closed Fracture & $\begin{array}{l}\text { A natural fracture that is completely filled with secondary minerals, and thus has no open } \\
\text { space along the fracture trace in the core. }\end{array}$ \\
\hline $\begin{array}{l}\text { Depth of } \\
\text { Fracture }\end{array}$ & $\begin{array}{l}\text { The depth below ground surface of the mid-point of the fracture recorded to the nearest tenth } \\
\text { of a foot. }\end{array}$ \\
\hline Fracture Type & $\begin{array}{l}\text { Joint: Fracture without displacement. } \\
\text { Fault: Fracture along which there has been displacement of the sides relative to one another. }\end{array}$ \\
\hline Fracture Width & $\begin{array}{l}\text { A representative distance in millimeters between the walls of the fracture, visually estimated } \\
\text { as representative for the portion of the fracture exposed in the core. Fracture walls are the } \\
\text { edges of the host rock containing the fracture. }\end{array}$ \\
\hline Fracture Density & The number of fractures per vertical foot. \\
\hline $\begin{array}{l}\text { Fracture } \\
\text { Orientation }\end{array}$ & $\begin{array}{l}\text { The dip of the fracture. (The acute angle formed by the fracture and a horizontal plane normal } \\
\text { to the long axis of the core, assuming the hole is vertical). }\end{array}$ \\
\hline $\begin{array}{l}\text { Fracture } \\
\text { Aperture }\end{array}$ & $\begin{array}{l}\text { The open distance in millimeters between the sides of the fracture, visually estimated as } \\
\text { representative for the portion of the fracture exposed in the core. The sides may consist of the } \\
\text { fracture walls where no secondary minerals are present, or the edges of secondary mineral } \\
\text { coatings. }\end{array}$ \\
\hline Percent Open & $\begin{array}{l}\text { The estimated percent of the open space (i.e., aperture) along the entire visible portion of a } \\
\text { fracture. When only a single fracture surface was available for examination, estimate of } \\
\text { percent open was based on the abundance, distribution, and crystal size of the minerals } \\
\text { observed on the fracture surface. }\end{array}$ \\
\hline $\begin{array}{l}\text { Secondary } \\
\text { Mineral Coatings }\end{array}$ & $\begin{array}{l}\text { Naturally occurring minerals that coat the surface of a fracture. Secondary mineralization } \\
\text { occurs after the formation of natural fractures, and, therefore, is indicative of natural fractures. }\end{array}$ \\
\hline Percent Coated & The estimated percent of the fracture surface that is coated with secondary minerals. \\
\hline Surface Texture & $\begin{array}{l}\text { The feel and appearance of the sides (i.e., surfaces) of a fracture. Texture was described as } \\
\text { very smooth, smooth, rough, very rough, or slickensided. } \\
\text { Very Smooth: A fracture surface that is flat and even and has a very smooth feel and } \\
\text { appearance. } \\
\text { Smooth: A fracture surface that has a very minor coarse feel and appearance. } \\
\text { Rough: A fracture surface that has a coarse and somewhat jagged feel and appearance. } \\
\text { Very Rough: A fracture surface that has a very coarse and jagged feel and appearance. } \\
\text { Slickensides: A polished fault surface. The surface feels slick and appears glossy and } \\
\text { shiny. Striations may be present. }\end{array}$ \\
\hline Fracture Shape & $\begin{array}{l}\text { The general shape of the fracture plane. Fracture shape was described as either planar } \\
\text { continuous, curved continuous, irregular continuous, planar discontinuous, curved } \\
\text { discontinuous, or irregular discontinuous. }\end{array}$ \\
\hline
\end{tabular}




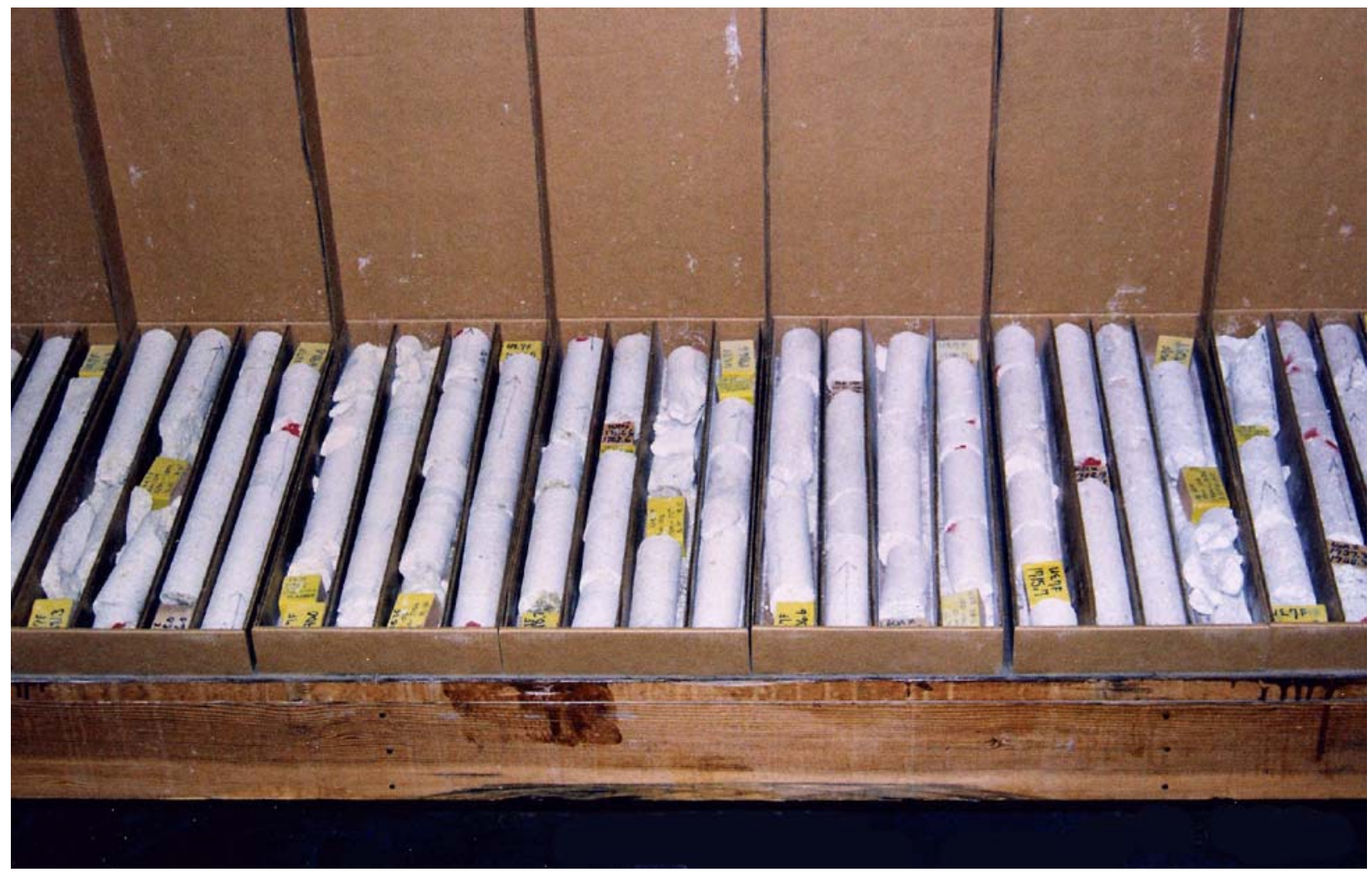

Figure 1-2

A Portion of UE-7f Core Laid Out for Fracture Analysis at the U.S. Geological Survey Geologic Data Center and Core Library in Mercury, Nevada

(Core boxes are approximately $0.91 \mathrm{~m}$ [3 ft] long.) 
Typically, core was examined megascopically; however, a 10x- to 40x-zoom binocular microscope was used for more detailed examination when necessary. Information on fracture attributes was entered on prepared, customized data sheets to assure consistency and completeness. Data collected were entered into Logplot $97^{\circledR} \log$ plotting software (a product of Rockware $^{\mathrm{TM}}$ ) for graphical presentations and into an Excel $^{\circledR}$ spreadsheet for statistical analysis Photographs of fractures observed in the cores were taken to provide clear illustrations of fracture attributes described and quantified during the study.

A total of 502 natural fractures was examined during the analysis. Because only natural fractures were of interest, it was necessary to differentiate between natural fractures and breaks induced during coring or handling (Figure 1-3). The presence of slickensides, offset bedding, or secondary mineral coatings on fracture surfaces is indicative of a natural fracture; therefore, all breaks in the cores were carefully examined for the presence of these characteristics (Figures 1-4 and 1-5).

Both open and closed natural fractures were examined during the analysis. The location of each fracture was recorded as the depth below ground level to the nearest tenth of a foot of the midpoint of the fracture. Each fracture was closely examined, and various attributes recorded. These included whether the fracture was a joint or fault, the shape of the fracture, surface texture, fracture width, fracture dip, size of any aperture present, percent open, presence of secondary minerals, and percent coated.

Although all fractures observed in the cores were examined and recorded, the limitations of sampling, preserving, and recognizing fractures in vertical core holes should be noted. For obvious reasons, it is impossible to obtain a representative sampling of vertical fractures in a vertical core hole. It can also be difficult to sample, preserve, and recognize large open joints and some faults in conventional core. Large open joints result in disjointed core segments, which can cause the core to jam, become highly broken, and/or cause the core to be lost. Even if the fracture is preserved in relatively good condition, it may be difficult to determine the original size of the aperture. Zones of argillic alteration and more intense fracturing are sometimes associated with faults. Such zones can also result in highly broken or missing core. The abundant clay present in argillic zones can obscure many features of the core, making it difficult to recognize individual fractures. 


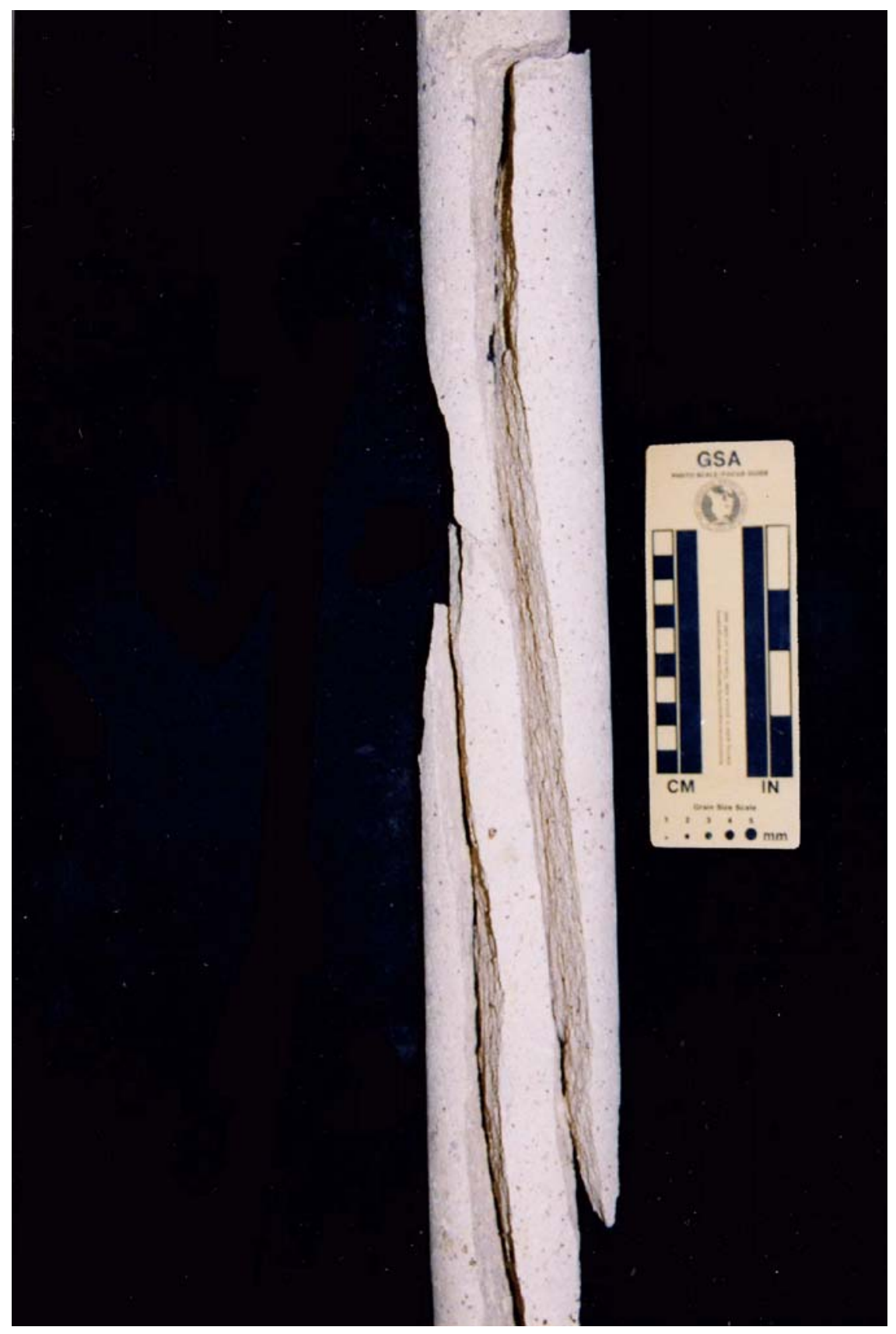

Note the following characteristics which are all typical of coring-induced breaks: near-vertical orientation, irregular trace, rough texture, and fresh appearance of the break surfaces. Core is from the 278.3-m (913-ft) depth in hole UE-7bc

Figure 1-3

Coring-Induced Breaks 


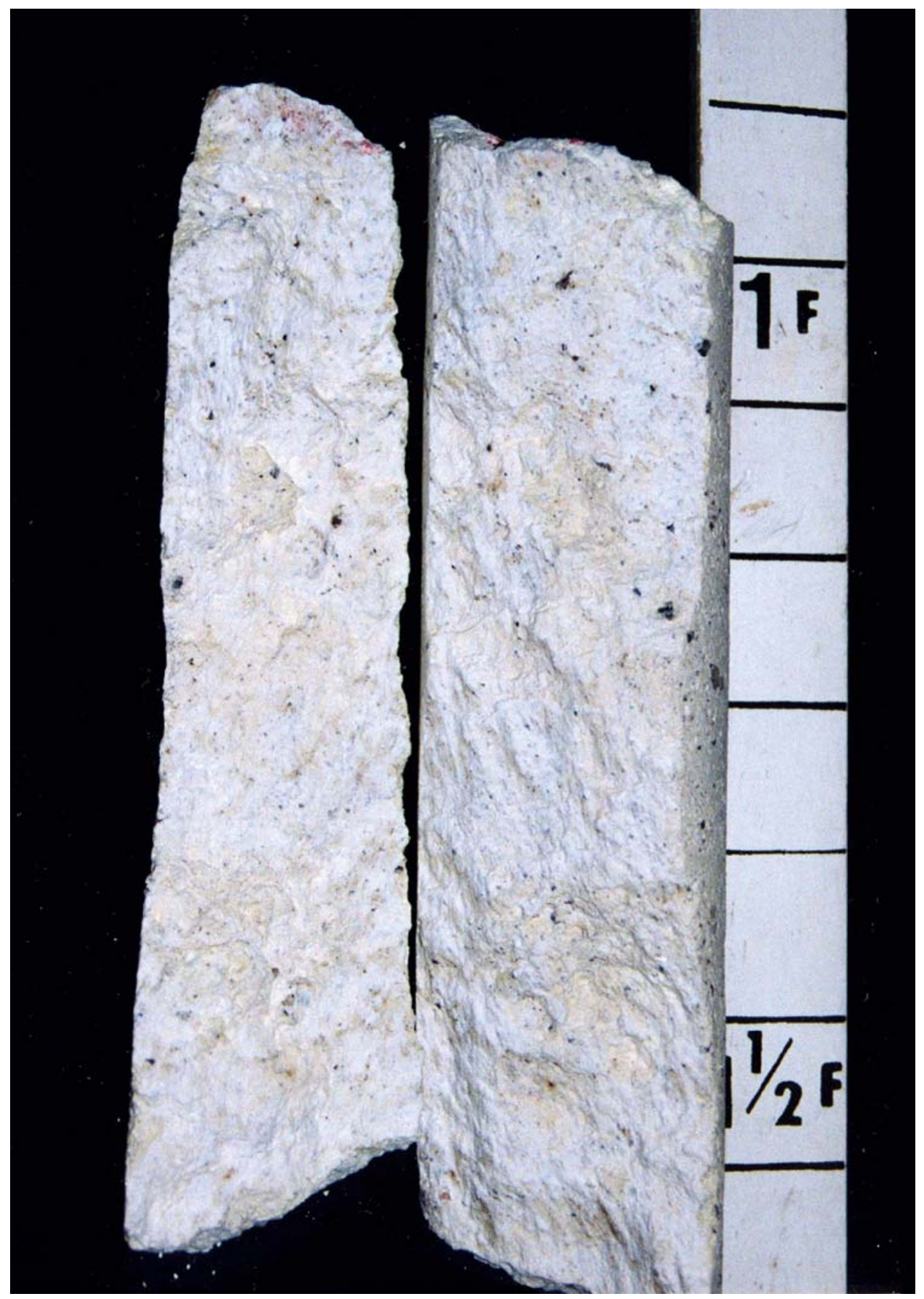

Note the near-vertical orientation and rough surface texture of this fracture, very similar to that shown in Figure 1-3. However, also note the secondary mineral coatings of white zeolite on the fracture surfaces, indicating that this is a natural fracture that broke apart during coring. Core is from the 489.2-m (1,605-ft) depth in hole UE-7az.

Figure 1-4

Natural Fracture 


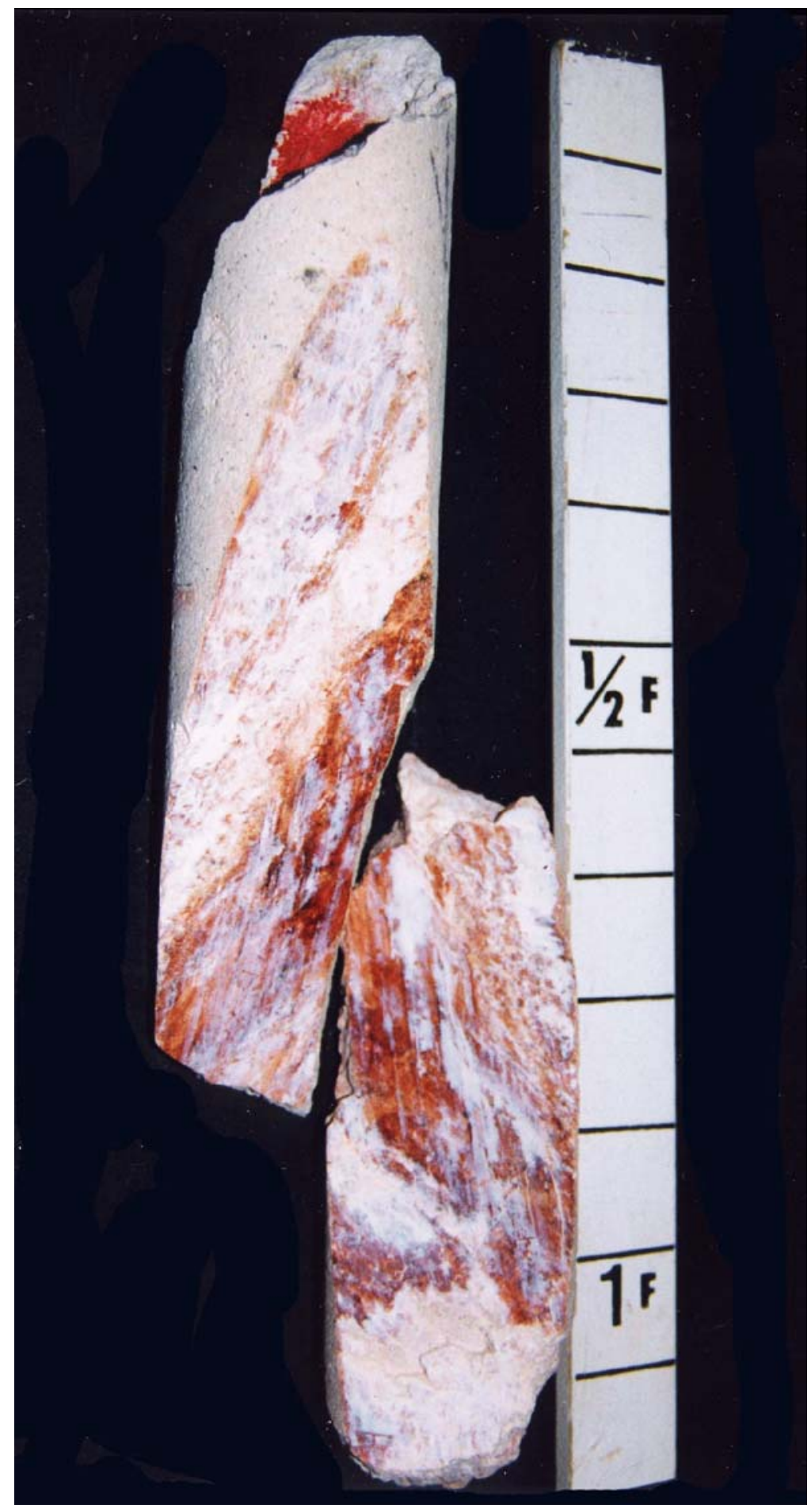

Note the striated secondary mineral coatings of reddish-orange iron oxide and white zeolite. Core is from the 544.4-m (1,786-ft) depth in hole UE-7az.

Figure 1-5

Natural Fracture with Well Developed Slickensides 


\subsection{Acknowledgments}

Several people provided critical support and assistance during this study. Jose Gonzales helped in recording fracture attributes and entering data into a spreadsheet format. Joel Metcalf produced statistical data on fracture attributes. Dawn Haugstad provided Figure 1-1. Appendix A was produced mainly through the efforts of Sigmund Drellack and Jose Gonzales. Margaret Townsend assisted with document preparation.

Access to the core analyzed during this study was facilitated by the staff of the U.S. Geological Survey’s Geologic Data Center and Core Library in Mercury, Nevada.

The following people performed technical reviews of this report and provided insightful and constructive suggestions: Gayle Pawloski of Lawrence Livermore National Laboratory, Chuck Russell of the Desert Research Institute, Wayne Belcher of the U.S. Geological Survey, and Greg Ruskauff of Stoller-Navarro Joint Venture. 
This page intentionally left blank. 


\subsection{Fracture Attributes}

This section describes and lists basic statistics for fracture attributes observed in core holes UE-7f, UE-7az, UE-7ba, and UE-7bc. The information provided in this section emphasizes fracture characteristics important to groundwater flow and radionuclide migration within the TCU, such as spacing, aperture, and secondary mineral coatings.

\subsection{Types of Fractures}

Seventy-two percent of the fractures observed were classified as joints, and 28 percent as faults (Table 2-1). Many of the joints have subtle, indistinct linear textures along their surfaces, and thus may actually be faults (Figure 2-1). Consequently, faults may represent a larger percentage of the fractures observed than indicated in Table 2-1.

Table 2-1

Types of Fractures

\begin{tabular}{||c|c|c|c|c|c||}
\hline \multirow{2}{*}{$\begin{array}{c}\text { Type of } \\
\text { Fracture }\end{array}$} & \multicolumn{4}{|c||}{ Core Hole } & \multirow{2}{*}{$\begin{array}{c}\text { Average for All } \\
\text { Four Core Holes }\end{array}$} \\
\cline { 2 - 5 } & UE-7f & UE-7az & UE-7ba & UE-7bc & $72 \%$ \\
\hline \hline Joint & $71 \%$ & $66 \%$ & $82 \%$ & $76 \%$ & $28 \%$ \\
\hline Fault & $29 \%$ & $34 \%$ & $18 \%$ & $24 \%$ & Foun \\
\hline
\end{tabular}

Most of the faults have poorly-developed slickensides, and less than $1 \mathrm{~cm}$ of normal offset (Figure 2-2). This indicates that most of the faults probably represent small, normal, dip-slip adjustments related to regional normal faulting, or to differential compaction.

\subsection{Fracture Shape and Orientation}

More than half of the fractures observed cut completely through the core along a straight plane, and thus were classified as planar and continuous in shape (Table 2-2). These fractures form a straight elliptical trace around the outside of the core (Figure 2-3). Other fractures were observed to be curved or irregular in shape (Figure 2-4). Almost 30 percent of the fractures appear to end within the core, and thus were classified as discontinuous. 
Table 2-2

Shapes of Fractures

\begin{tabular}{||c|c|c|c|c|c||}
\hline \multirow{2}{*}{ Fracture Shape } & \multicolumn{4}{|c||}{ Core Hole } & \multirow{2}{*}{$\begin{array}{c}\text { Average for All } \\
\text { Four Holes }\end{array}$} \\
\cline { 2 - 6 } & UE-7f & UE-7az & UE-7ba & UE-7bc & $51 \%$ \\
\hline \hline Planar and Continuous & $60 \%$ & $46 \%$ & $45 \%$ & $41 \%$ & $8 \%$ \\
\hline Curved and Continuous & $8 \%$ & $8 \%$ & $9 \%$ & $10 \%$ & $17 \%$ \\
\hline Irregular and Continuous & $11 \%$ & $6 \%$ & $21 \%$ & $17 \%$ & $11 \%$ \\
\hline $\begin{array}{c}\text { Planar and } \\
\text { Discontinuous }\end{array}$ & $11 \%$ & $10 \%$ & $15 \%$ & $9 \%$ & $4 \%$ \\
\hline $\begin{array}{c}\text { Curved and } \\
\text { Discontinuous }\end{array}$ & $1 \%$ & $8 \%$ & $3 \%$ & $3 \%$ & $14 \%$ \\
\hline $\begin{array}{c}\text { Irregular and } \\
\text { Discontinuous }\end{array}$ & $9 \%$ & $22 \%$ & $7 \%$ & $20 \%$ & \\
\hline \hline
\end{tabular}

Fracture shape provides information on fracture interconnectivity and the tortuosity of flow paths through the fracture, as well as through the host rock itself. Fractures with planar shapes are characteristic of systematic fracture sets (Twiss and Moores, 1992). Systematic fractures tend to be straighter, more through-going, and extensive. Thus, if open, they provide more direct flow paths. Curved or irregular shapes are characteristic of nonsystematic fractures. Nonsystematic fractures tend to terminate against systematic fractures, and thus may provide important interconnective pathways between systematic fractures. However, flow paths within nonsystematic fractures will be considerably more tortuous than those in systematic fractures.

The dips of fractures range from $15^{\circ}$ to vertical $\left(90^{\circ}\right)$. These values should be considered approximations because dip determinations assume the core hole is perfectly vertical. Table 2-3 shows that the average dip of the fractures for all four holes is $69^{\circ}$.

Table 2-3

Dips of Fractures

\begin{tabular}{||c|c|c|c|c|c||}
\hline \multirow{2}{*}{ Fracture Dip } & \multicolumn{4}{|c||}{ Core Hole } & \multirow{2}{*}{$\begin{array}{c}\text { Average for All } \\
\text { Four Holes }\end{array}$} \\
\cline { 2 - 5 } & UE-7f & UE-7az & UE-7ba & UE-7bc & $69^{\circ}$ \\
\hline \hline $\begin{array}{c}\text { Average Dip } \\
\text { of Fractures }\end{array}$ & $69^{\circ}$ & $64^{\circ}$ & $69^{\circ}$ & $75^{\circ}$ & $69^{\circ}$ \\
\hline
\end{tabular}




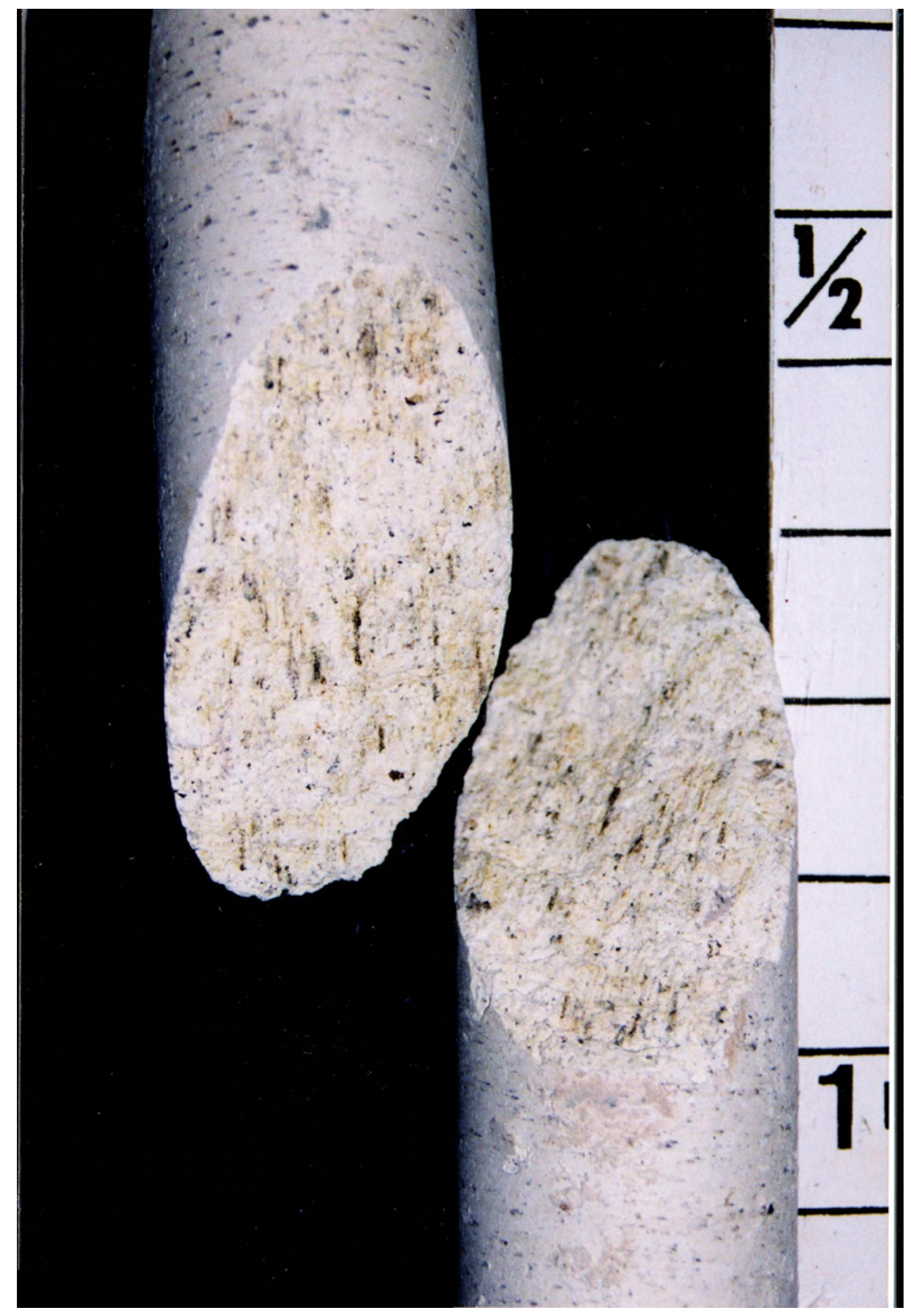

Core is from the 425.5-m (1,396-ft) depth in UE-7az.

Figure 2-1

Natural Fracture Showing a Subtle Linear Texture on Fracture Surfaces 


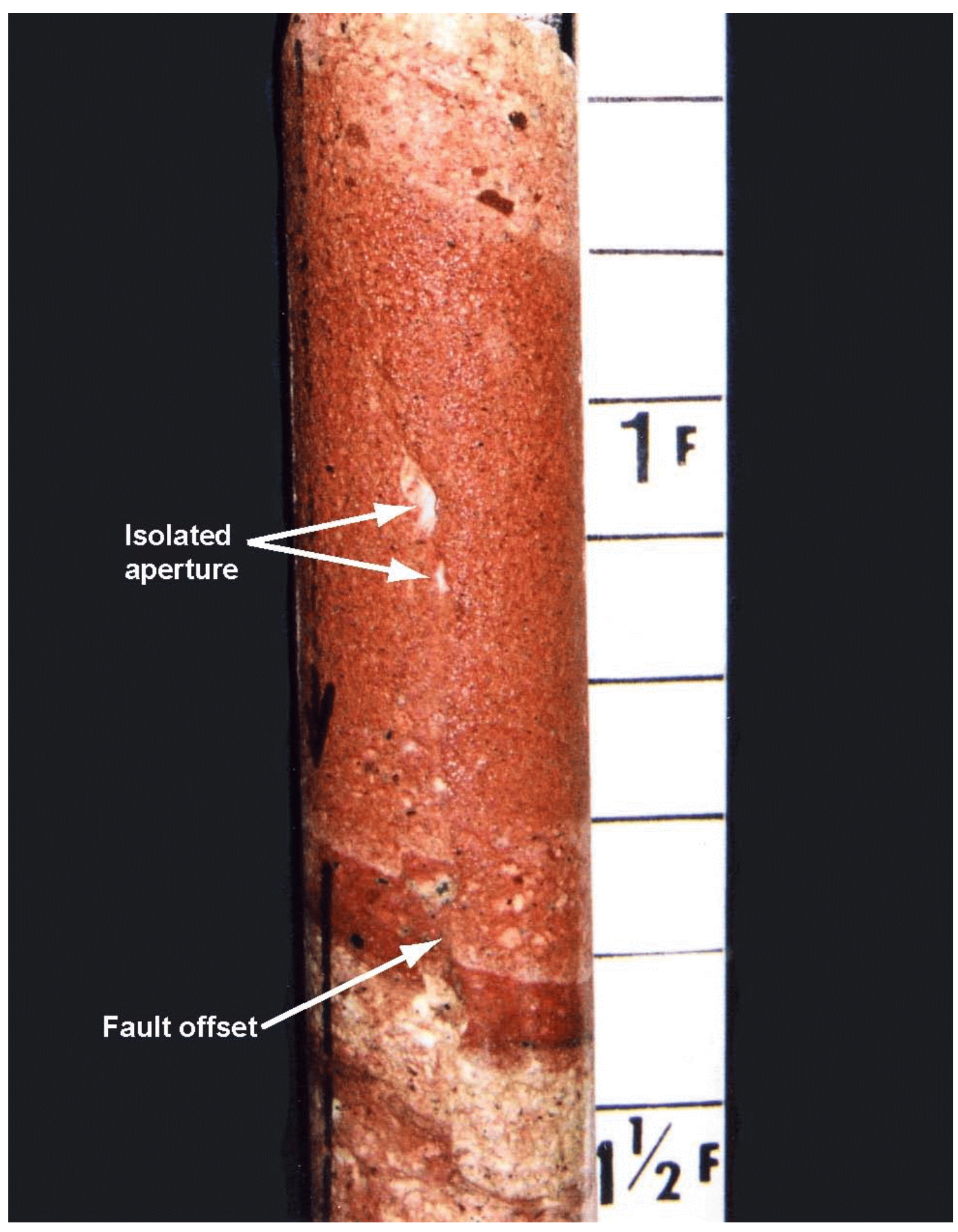

Note 1-cm offset of bedding at bottom of photograph. Also note the discontinuous trace with isolated aperture. Core is from the 557.5-m (1,829-ft) depth in hole UE-7az. Core was moistened prior to photographing to better reveal details.

Figure 2-2

\section{Small Normal Fault}




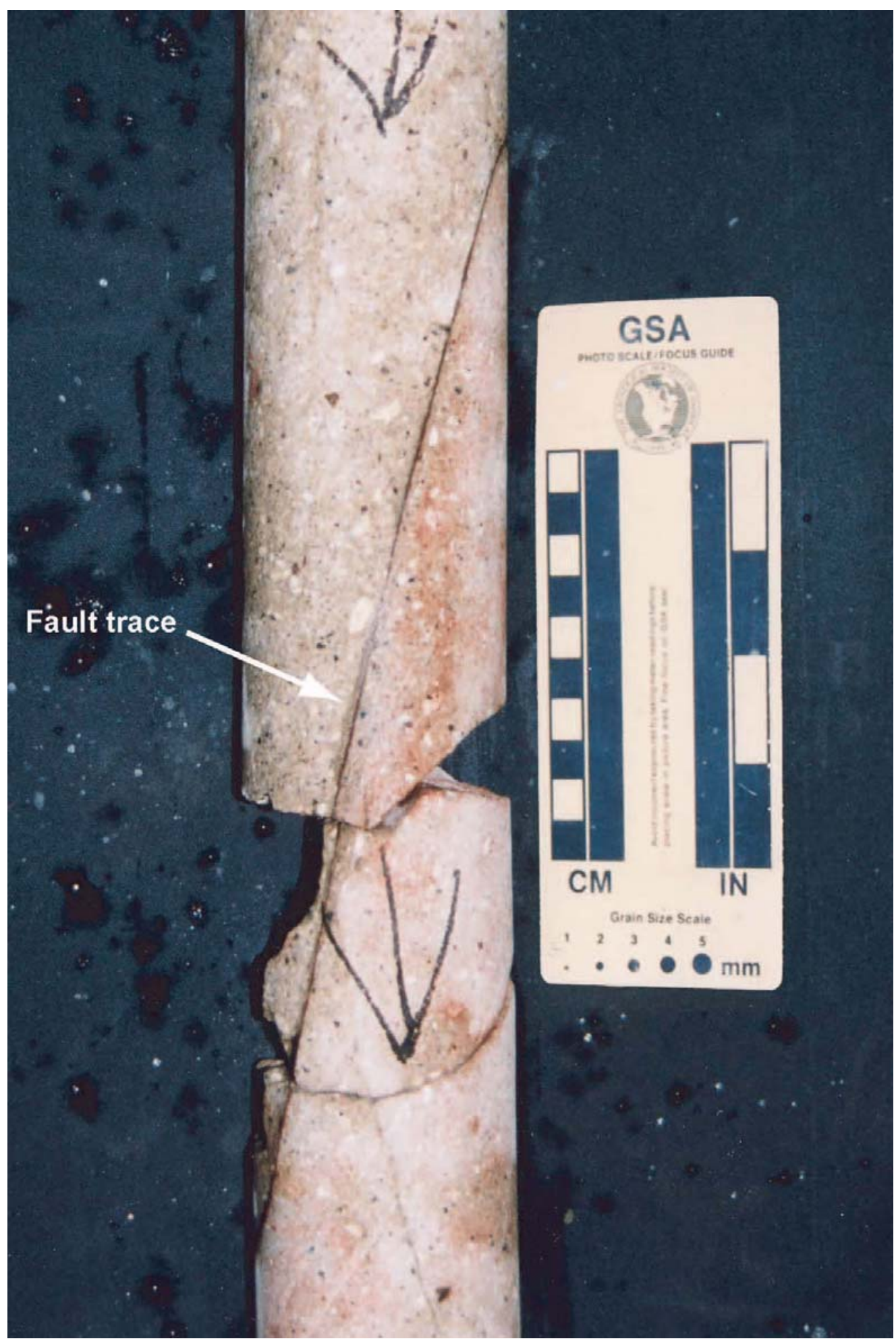

This fracture is a fault dipping $75^{\circ}$. Note the thin ( 0.5 millimeter) width, planar and continuous shape, and lack of any visible aperture. Fault appears to be filled with metallic oxides. Black arrows on core point down-hole. Core is from the 538.6-m (1,767-ft) depth in hole UE-7f.

Figure 2-3

Natural Fracture with a Planar, Continuous Shape 


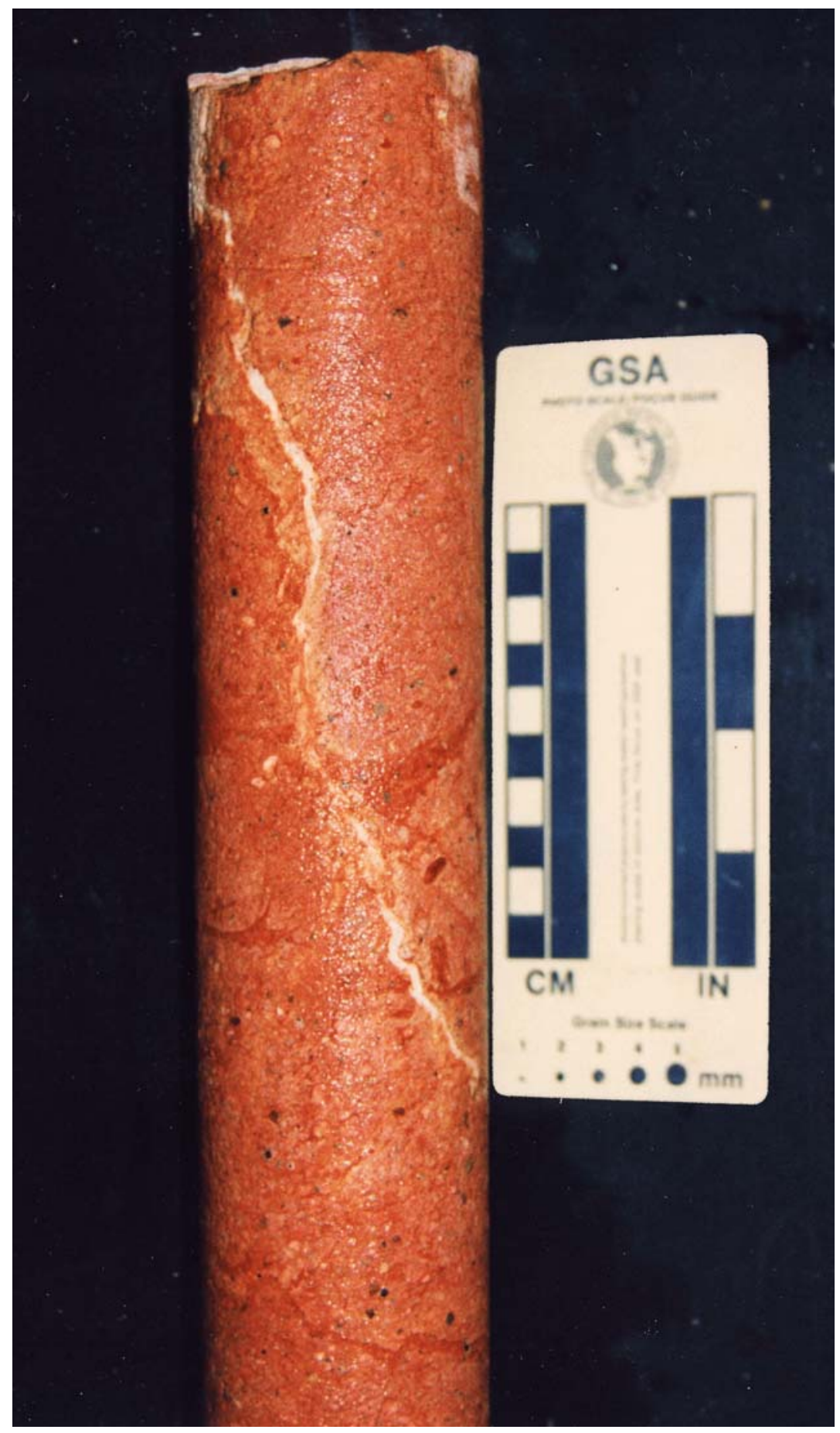

This irregular, continuous fracture is completely filled with white zeolite. Core is from the $628.8-\mathrm{m}(2,063-\mathrm{ft})$ depth in hole UE-7f. Core was moistened prior to photographing to better reveal details.

Figure 2-4

Natural Fracture with an Irregular, Continuous Shape 
Because core orientation had not been marked on the cores during drilling, it is impossible to determine strike of the fractures or the direction of dip. However, it is reasonable to assume that many of the fractures formed in response to the same stresses as the larger structures mapped at the surface and in the subsurface in the vicinity of Yucca Flat, and thus are oriented similarly. Most faults in the Yucca Flat vicinity strike in a northerly direction and dip steeply in either eastward or westward (Frizzell and Shulters, 1990).

\subsection{Fracture Density and Spacing}

Figures 2-5 through 2-8 show the vertical distribution of fractures in the four core holes. The stratigraphic and lithologic columns are based on original unpublished detailed lithologic logs held in the weapons testing program files at NSTec. Stratigraphic nomenclature was updated where appropriate using nomenclature from Ferguson et al. (1994). The figures show that greater fracture densities generally are seen in rocks older than the Grouse Canyon Tuff. The distribution of fractures appears to be independent of lithology. The general scarcity of fractures observed in the argillic rocks, particularly in UE-7az, is probably due partly to the difficulty in recognizing fractures in the highly altered and mechanically broken core segments of these rocks (Figure 2-9). In any case, the intense argillic alteration observed in many of these rocks probably precludes the formation and existence of extensive open fractures. This is due to the non-brittle character of argillic tuffs, and the likelihood that any fractures that are present are filled with clay. The latter condition is observed in the underlying Paleozoic-age carbonate rocks where fractures in carbonate rocks that directly underlie the argillic tuffs are completely filled with clay (Figure 2-10).

Tables 2-4a and 2-4b show that 502 fractures were observed in 1,842.5 m (6,045 ft) of core. Of these, 116 fractures, or 23 percent, were observed to be at least partially open (i.e., observed to have some aperture). Drill holes UE-7f and UE-7az show the highest density of fractures, at about 0.43 fractures per vertical meter of core ( 0.13 fractures per vertical foot of core), followed by UE-7ba and UE-7bc at 0.19 and 0.12 fractures per vertical meter of core (0.06 and 0.04 fractures per vertical foot of core), respectively. The average fracture density for all four holes is 0.27 fractures per vertical meter of core (0.08 fractures per vertical foot of core).

The density of open fractures in each of the four holes is considerably less than that for all fractures (Tables 2-4a and 2-4b). Densities for open fractures range from an average of 0.12 fractures per vertical meter of core ( 0.04 fractures per vertical foot of core) in UE- $7 \mathrm{f}$ to 0.01 fractures per vertical meter of core ( 0.004 fractures per vertical foot of core) in UE-7bc. The average for all four holes is 0.06 fractures per vertical meter of core ( 0.02 fractures per vertical foot of core). 


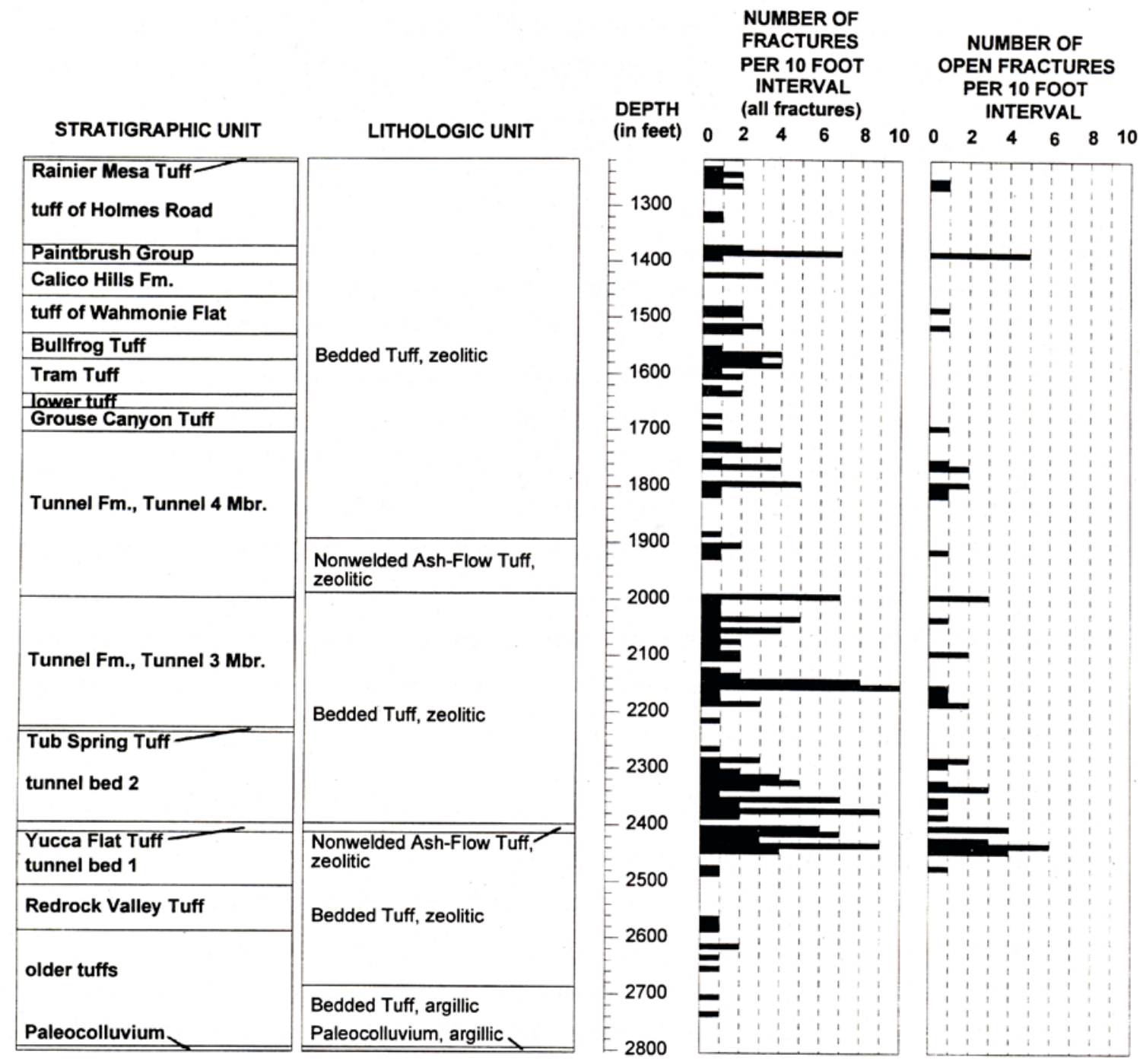

Figure 2-5

Vertical Distribution of Fractures within the TCU in UE-7f 


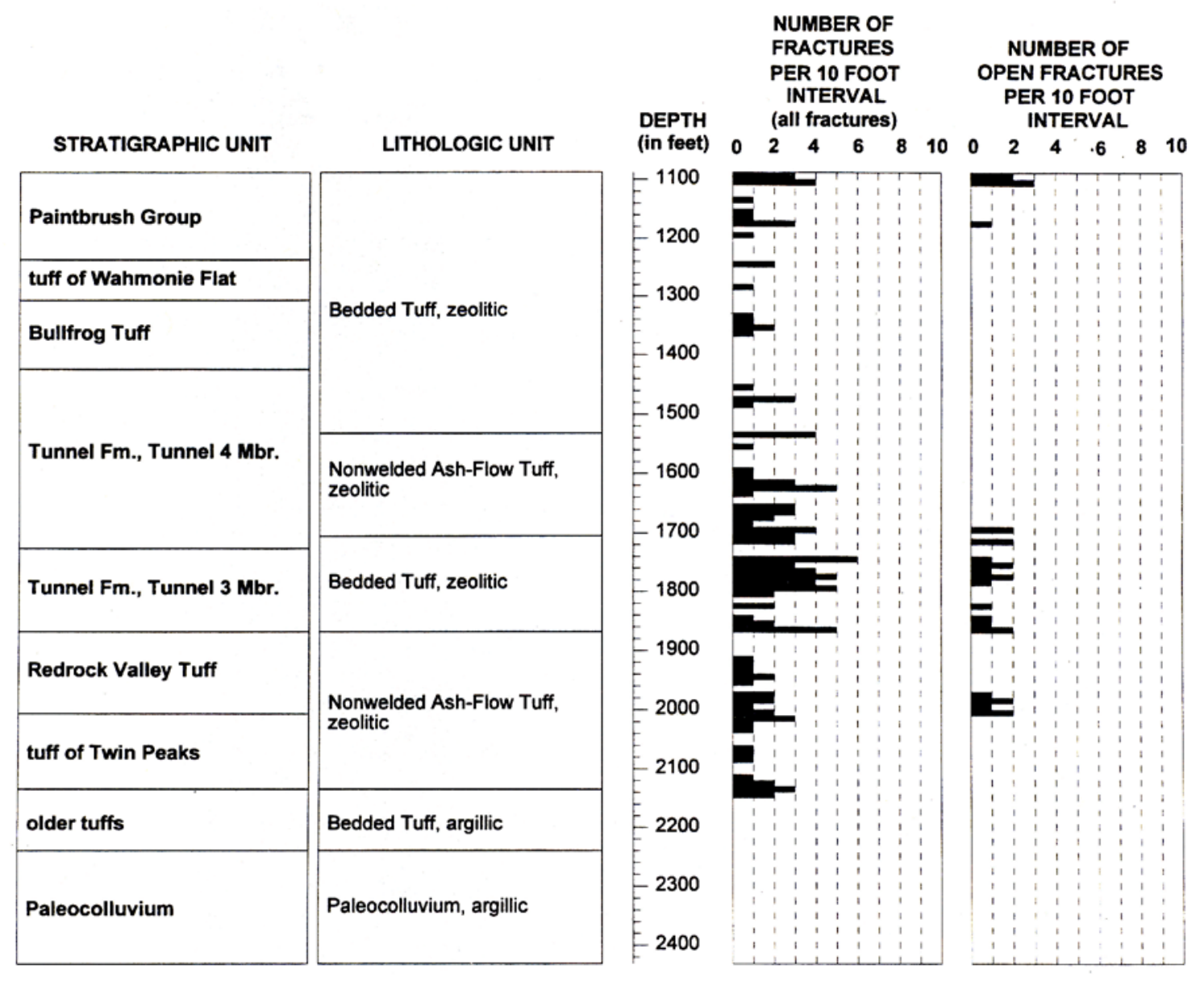

Figure 2-6

Vertical Distribution of Fractures within the TCU in UE-7az 


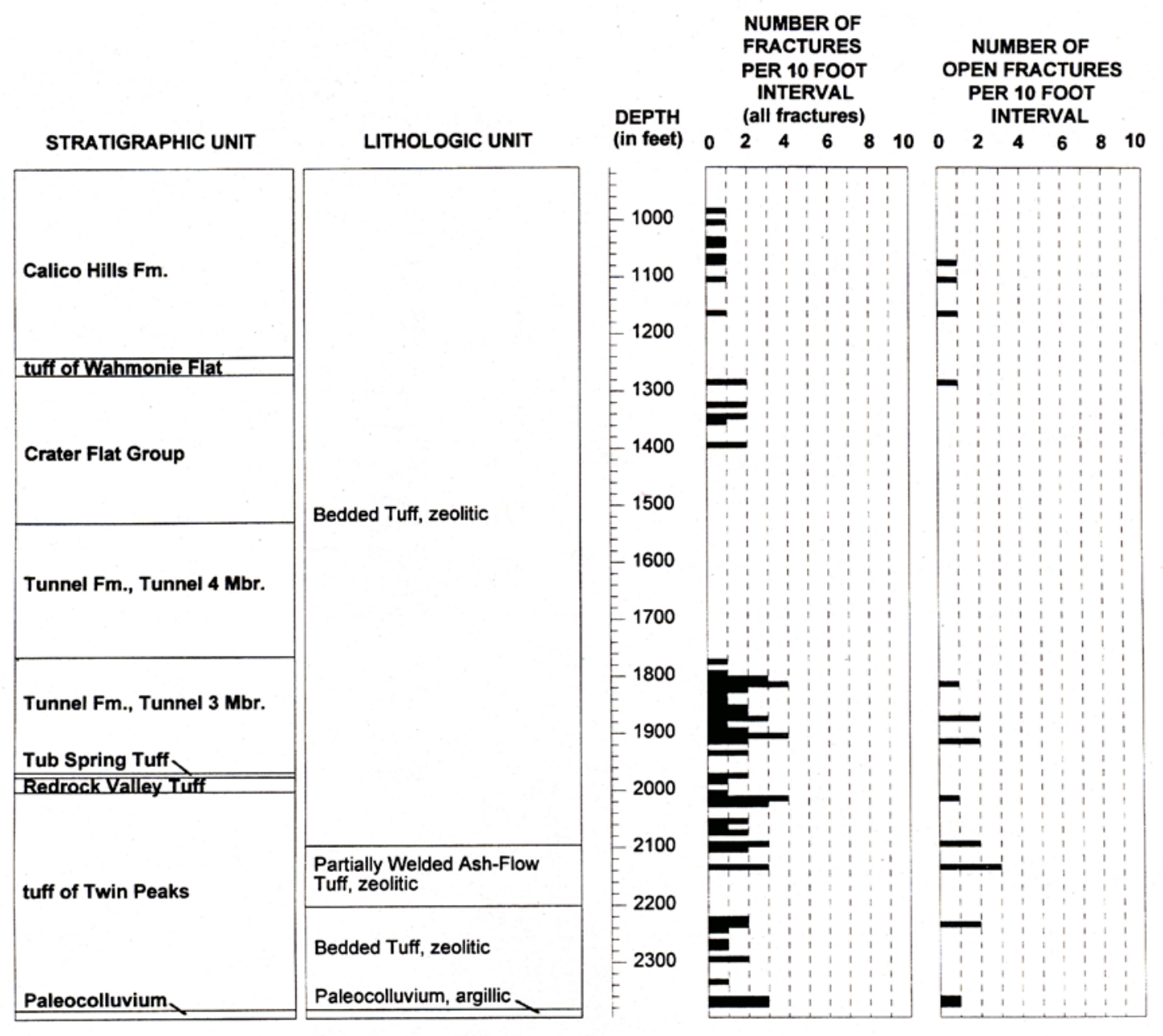

Figure 2-7

Vertical Distribution of Fractures within the TCU in UE-7ba 


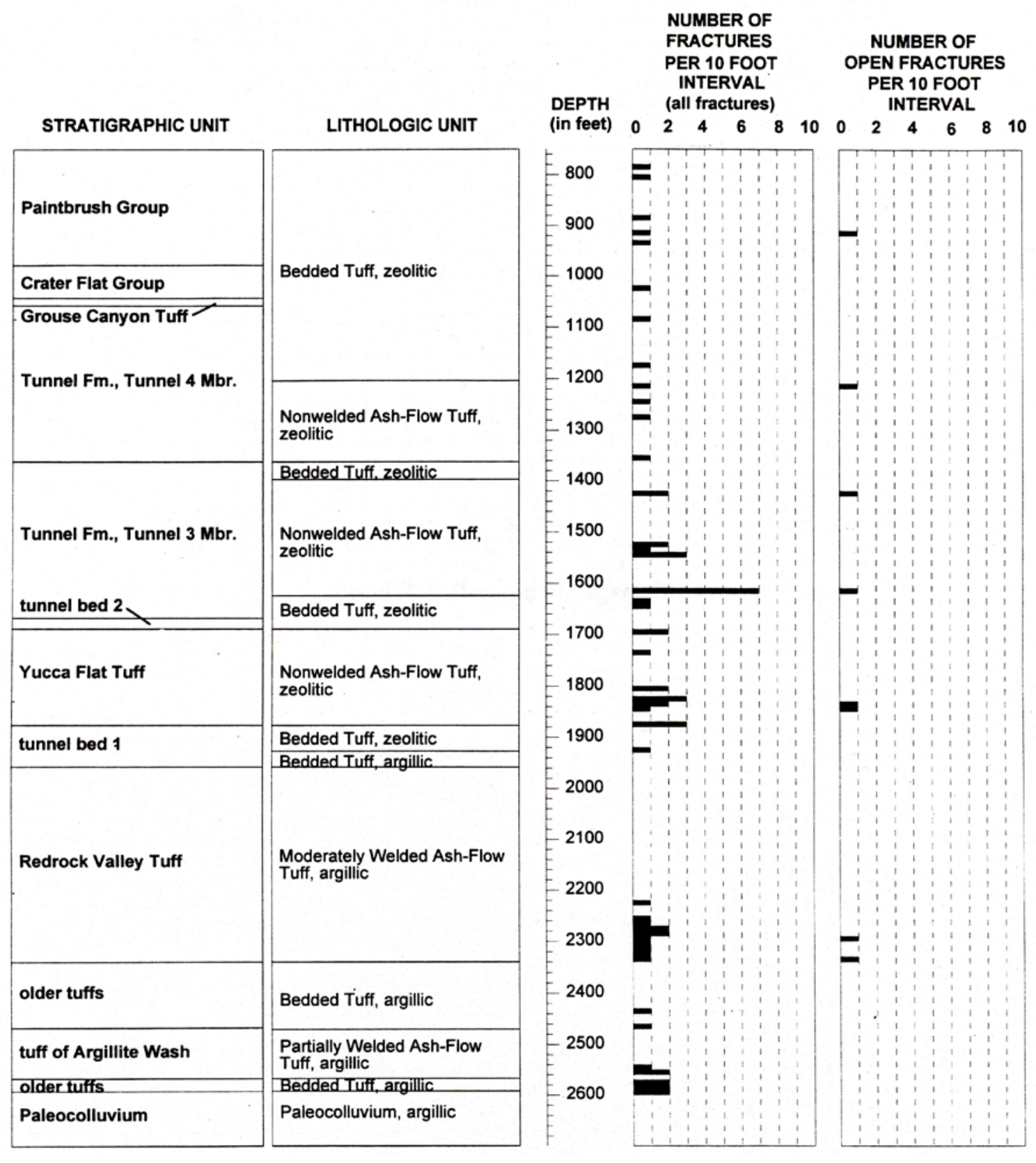

Figure 2-8

Vertical Distribution of Fractures within the TCU in UE-7bc 


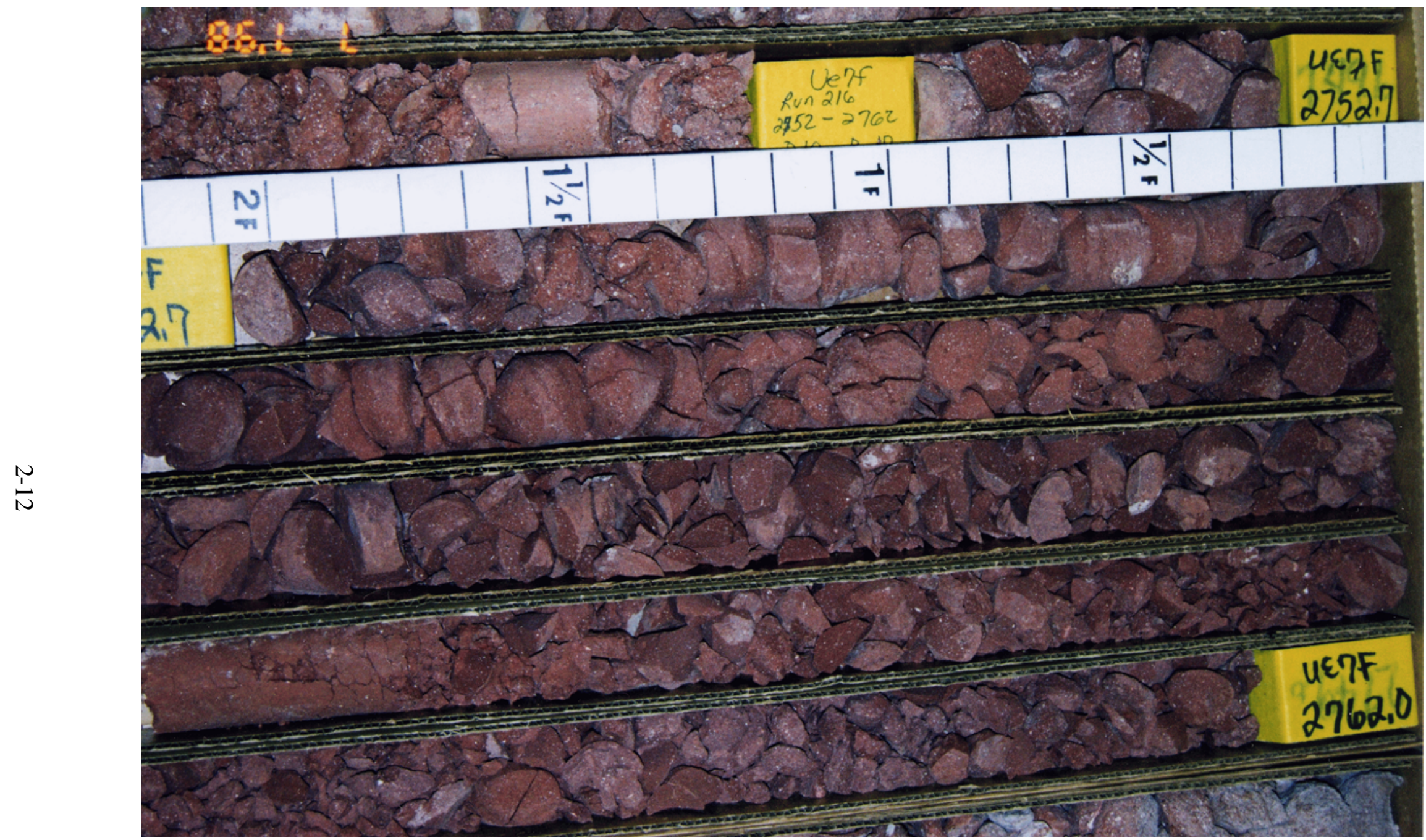

This core was highly broken up during the coring process. Sample is from the interval 838.8 to $841.9 \mathrm{~m}(2,752 \mathrm{to} 2,762 \mathrm{ft})$ in UE-7f.

Figure 2-9

Argillic Tuff Showing Highly Broken Character 


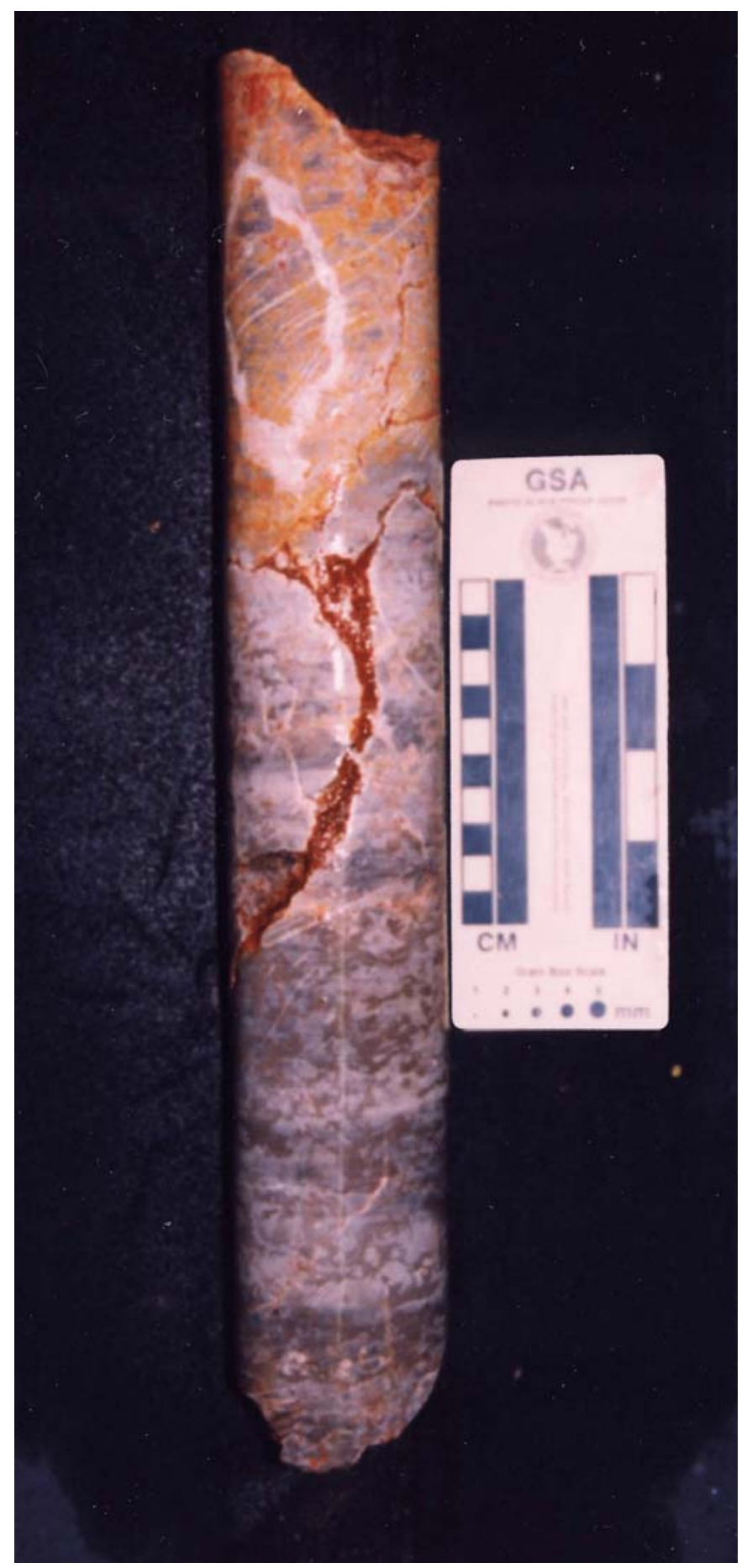

Note the reddish-brown clay that fills fracture in gray limestone. This fracture is at the very top of the Pre-Tertiary section in this core hole. Highly argillized, reddish-brown, tuffaceous paleocolluvium directly overlies the Pre-Tertiary rocks and is probably the source of the clay. Core is from the 730.9-m (2,398-ft) depth in UE-7ba. Core was moistened prior to photographing to better reveal details.

Figure 2-10

Clay-Filled Fracture in Paleozoic-Age Limestone 
Table 2-4a

Fracture Density and Spacing

(in meters)

\begin{tabular}{|c|c|c|c|c|c|}
\hline \multirow{2}{*}{ Attribute } & \multicolumn{4}{|c|}{ Core Hole } & \multirow{2}{*}{$\begin{array}{c}\text { Total/Average } \\
\text { for All Four } \\
\text { Holes }\end{array}$} \\
\hline & UE-7f & UE-7az & UE-7ba & UE-7bc & \\
\hline $\begin{array}{l}\text { Total Length of Interval } \\
\text { Analyzed }\end{array}$ & $477.0 \mathrm{~m}$ & $322.5 \mathrm{~m}$ & $449.0 \mathrm{~m}$ & $594.1 \mathrm{~m}$ & $\begin{array}{l}1,842.5 \mathrm{~m} \\
\text { (Total) }\end{array}$ \\
\hline $\begin{array}{l}\text { Number of Fractures } \\
\text { Observed }\end{array}$ & 211 & 134 & 87 & 70 & $\begin{array}{c}502 \\
\text { (Total) }\end{array}$ \\
\hline $\begin{array}{l}\text { Number of Open } \\
\text { Fractures Observed }\end{array}$ & 58 & 31 & 19 & 8 & $\begin{array}{l}116 \\
\text { (Total) }\end{array}$ \\
\hline $\begin{array}{l}\text { Percent of Fractures } \\
\text { that are Open }\end{array}$ & $27 \%$ & $23 \%$ & $22 \%$ & $11 \%$ & $\begin{array}{c}23 \% \\
\text { (Average) }\end{array}$ \\
\hline $\begin{array}{l}\text { Fracture Density } \\
\text { (number of fractures per } \\
\text { vertical meter of core) }\end{array}$ & 0.44 & 0.42 & 0.19 & 0.12 & $\begin{array}{c}0.27 \\
\text { (Average) }\end{array}$ \\
\hline $\begin{array}{l}\text { Density of Open } \\
\text { Fractures } \\
\text { (number of open } \\
\text { fractures per vertical } \\
\text { meter of core) }\end{array}$ & 0.12 & 0.10 & 0.04 & 0.01 & $\begin{array}{c}0.06 \\
\text { (Average) }\end{array}$ \\
\hline $\begin{array}{l}\text { Apparent Spacing, } \\
\text { All Fractures } \\
\text { (vertical distance } \\
\text { between fractures) }\end{array}$ & $2.2 \mathrm{~m}$ & $2.4 \mathrm{~m}$ & $4.9 \mathrm{~m}$ & $8.0 \mathrm{~m}$ & $\begin{array}{c}3.5 \mathrm{~m} \\
\text { (Average) }\end{array}$ \\
\hline $\begin{array}{l}\text { Apparent Spacing, } \\
\text { Open Fractures Only } \\
\text { (vertical distance } \\
\text { between fractures) }\end{array}$ & $6.8 \mathrm{~m}$ & $9.4 \mathrm{~m}$ & $21.9 \mathrm{~m}$ & $62.3 \mathrm{~m}$ & $\begin{array}{c}13.6 \mathrm{~m} \\
\text { (Average) }\end{array}$ \\
\hline $\begin{array}{l}\text { True Spacing, } \\
\text { All Fractures }\end{array}$ & $0.8 \mathrm{~m}$ & $1.1 \mathrm{~m}$ & $1.7 \mathrm{~m}$ & $2.1 \mathrm{~m}$ & $\begin{array}{c}1.3 \mathrm{~m} \\
\text { (Average) }\end{array}$ \\
\hline $\begin{array}{l}\text { True Spacing, } \\
\text { Open Fractures Only }\end{array}$ & $2.4 \mathrm{~m}$ & $4.2 \mathrm{~m}$ & $7.7 \mathrm{~m}$ & $16.1 \mathrm{~m}$ & $\begin{array}{c}5.0 \mathrm{~m} \\
\text { (Average) }\end{array}$ \\
\hline
\end{tabular}


Table 2-4b

Fracture Density and Spacing

(in feet)

\begin{tabular}{|c|c|c|c|c|c|}
\hline \multirow{2}{*}{ Attribute } & \multicolumn{4}{|c|}{ Core Hole } & \multirow{2}{*}{$\begin{array}{c}\text { Total/Average } \\
\text { for all Four } \\
\text { Holes }\end{array}$} \\
\hline & UE-7f & UE-7az & UE-7ba & UE-7bc & \\
\hline Total Footage Analyzed & $1,565 \mathrm{ft}$ & $1,058 \mathrm{ft}$ & $1,473 \mathrm{ft}$ & $1,949 \mathrm{ft}$ & $\begin{array}{l}6,045 \mathrm{ft} \\
\text { (Total) }\end{array}$ \\
\hline $\begin{array}{l}\text { Number of Fractures } \\
\text { Observed }\end{array}$ & 211 & 134 & 87 & 70 & $\begin{array}{c}502 \\
\text { (Total) }\end{array}$ \\
\hline $\begin{array}{l}\text { Number of Open } \\
\text { Fractures Observed }\end{array}$ & 58 & 31 & 19 & 8 & $\begin{array}{c}116 \\
\text { (Total) }\end{array}$ \\
\hline $\begin{array}{l}\text { Percent of Fractures } \\
\text { that are Open }\end{array}$ & $27 \%$ & $23 \%$ & $22 \%$ & $11 \%$ & $\begin{array}{c}23 \% \\
\text { (Average) }\end{array}$ \\
\hline $\begin{array}{l}\text { Fracture Density } \\
\text { (number of fractures per } \\
\text { vertical foot of core) }\end{array}$ & 0.13 & 0.13 & 0.06 & 0.04 & $\begin{array}{c}0.08 \\
\text { (Average) }\end{array}$ \\
\hline $\begin{array}{l}\text { Density of Open } \\
\text { Fractures } \\
\text { (number of open } \\
\text { fractures per vertical foot } \\
\text { of core) }\end{array}$ & 0.04 & 0.03 & 0.01 & 0.004 & $\begin{array}{c}0.02 \\
\text { (Average) }\end{array}$ \\
\hline $\begin{array}{l}\text { Apparent Spacing } \\
\text { All Fractures } \\
\text { (vertical distance } \\
\text { between fractures) }\end{array}$ & $7 \mathrm{ft}$ & $8 \mathrm{ft}$ & $16 \mathrm{ft}$ & $26 \mathrm{ft}$ & $\begin{array}{c}12 \mathrm{ft} \\
\text { (Average) }\end{array}$ \\
\hline $\begin{array}{l}\text { Apparent Spacing } \\
\text { Open Fractures Only } \\
\text { (vertical distance } \\
\text { between fractures) }\end{array}$ & $22 \mathrm{ft}$ & $31 \mathrm{ft}$ & $72 \mathrm{ft}$ & $204 \mathrm{ft}$ & $\begin{array}{c}45 \mathrm{ft} \\
\text { (Average) }\end{array}$ \\
\hline $\begin{array}{l}\text { True Spacing, } \\
\text { All Fractures }\end{array}$ & $3 \mathrm{ft}$ & $4 \mathrm{ft}$ & $6 \mathrm{ft}$ & $7 \mathrm{ft}$ & $\begin{array}{c}4 \mathrm{ft} \\
\text { (Average) }\end{array}$ \\
\hline $\begin{array}{l}\text { True Spacing, } \\
\text { Open Fractures Only }\end{array}$ & $8 \mathrm{ft}$ & $14 \mathrm{ft}$ & $25 \mathrm{ft}$ & $53 \mathrm{ft}$ & $\begin{array}{c}16 \mathrm{ft} \\
\text { (Average) }\end{array}$ \\
\hline
\end{tabular}

Tables 2-4a and 2-4b show that cores from holes UE-7f and UE-7az have greater densities of fractures than cores from UE-7ba and UE-7bc. The reason for the greater densities is uncertain. However, underground nuclear testing can be ruled out as the cause of the differences because almost all the fractures recorded have secondary minerals associated with them, and thus are natural fractures. Fractures are often associated with other structural features, such as faults 
(Twiss and Moores, 1992). Therefore, the difference in densities could be related to the position of the holes relative to the larger, basin-forming faults in Yucca Flat. However, a look at the position of the core holes relative to faults mapped at the surface and in the subsurface in Yucca Flat revealed no obvious relationships between fracture densities and the position of the holes relative to these faults.

The apparent fracture spacing (i.e., vertical distance between fractures) for all fractures ranges from an average of $2.2 \mathrm{~m}(7 \mathrm{ft})$ in UE-7f to $8.0 \mathrm{~m}$ (26 ft) in UE-7bc. The average for all the holes

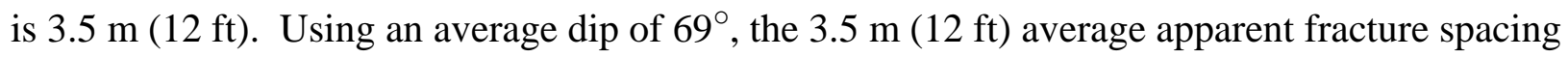
can be corrected to an average true spacing of $1.3 \mathrm{~m}(4 \mathrm{ft})$. However, this corrected value is a minimum, as it assumes all the fractures belong to the same fracture set and have similar orientations.

Considering only open fractures, the apparent fracture spacing ranges from $6.8 \mathrm{~m}(22 \mathrm{ft})$ in UE-7f

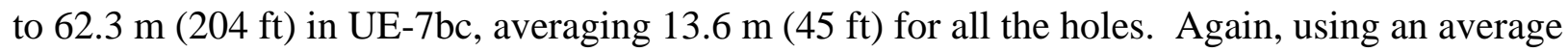
dip of $69^{\circ}$, the average true spacing (i.e., the minimum distance between parallel fractures) of open fractures for all the holes is $5.0 \mathrm{~m}(16 \mathrm{ft})$.

\subsection{Fracture Width, Aperture, and Openness}

Fractures range in width from 0.1 to 10 millimeters (mm), averaging $0.8 \mathrm{~mm}$ (Table 2-5). Some fractures have no visible trace, and were recognized only by an obvious alignment of openings along the outside of the core (Figure 2-11). In addition, it seemed that some fractures might not have been recognized if the core had not broken along the fracture to reveal thin secondary mineral coatings along the fracture surface.

Aperture ranges from $0.1 \mathrm{~mm}$ or less to $10 \mathrm{~mm}$, averaging $1.1 \mathrm{~mm}$. Aperture generally appears as small isolated openings along the trace of the fracture (Figures 2-2 and 2-11). Only a few large (greater than $5 \mathrm{~mm}$ ) through-going openings were observed (Figure 2-12). On average, fractures with aperture consist of only 10 percent open space (i.e., aperture).

Some of the aperture observed may have resulted from minor movement along fault planes. Openings formed by separation along small steps in the fault plane could have formed isolated aperture along the fault. 


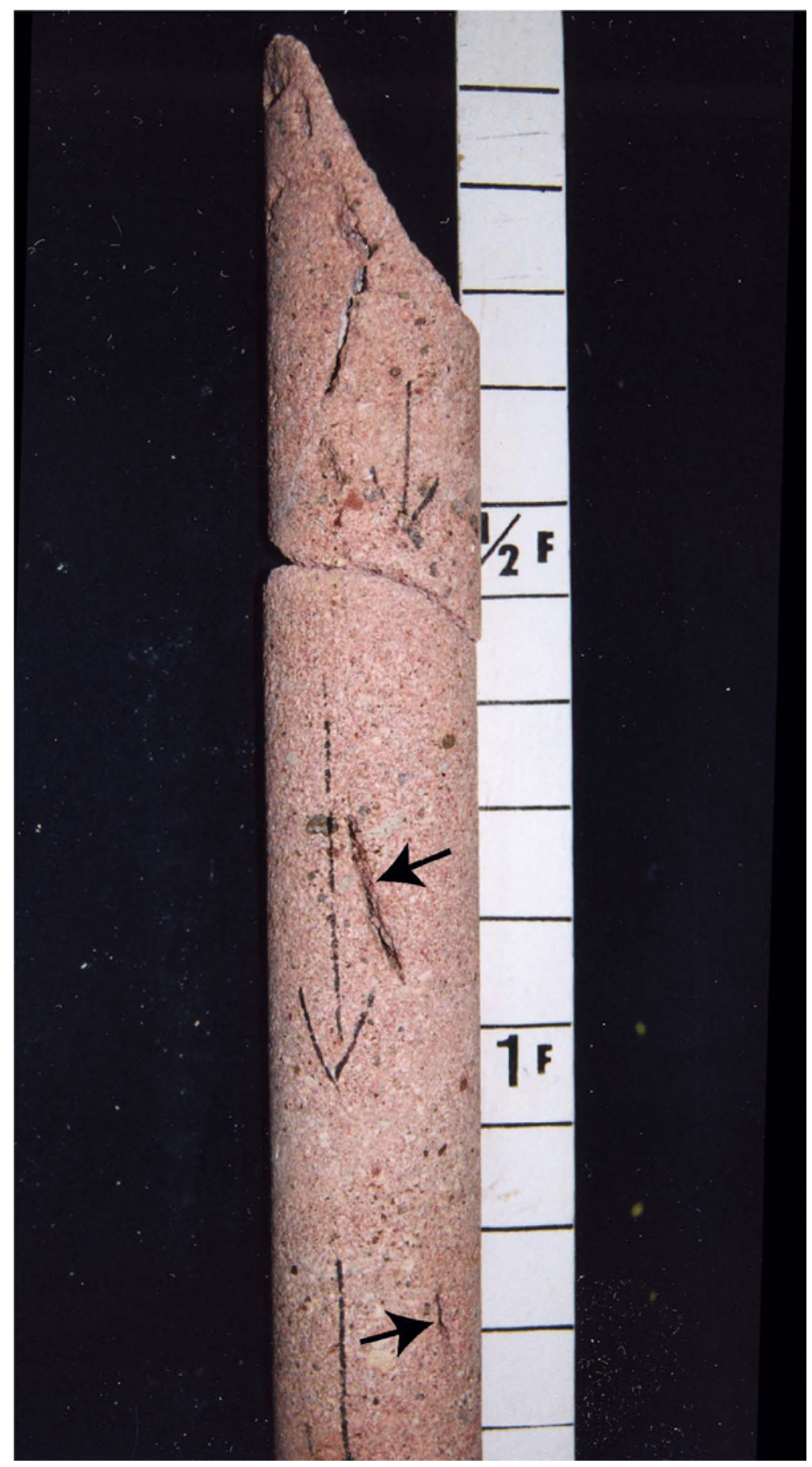

Note alignment of aperture (small black arrows) along outside of core with no visible trace connecting aperture. Large black arrows on core show down-hole direction. Cores is from the 562.4-m (1,845-ft) depth in hole UE-7az.

Figure 2-11

Alignment of Aperture Along Outer Surface of Core 


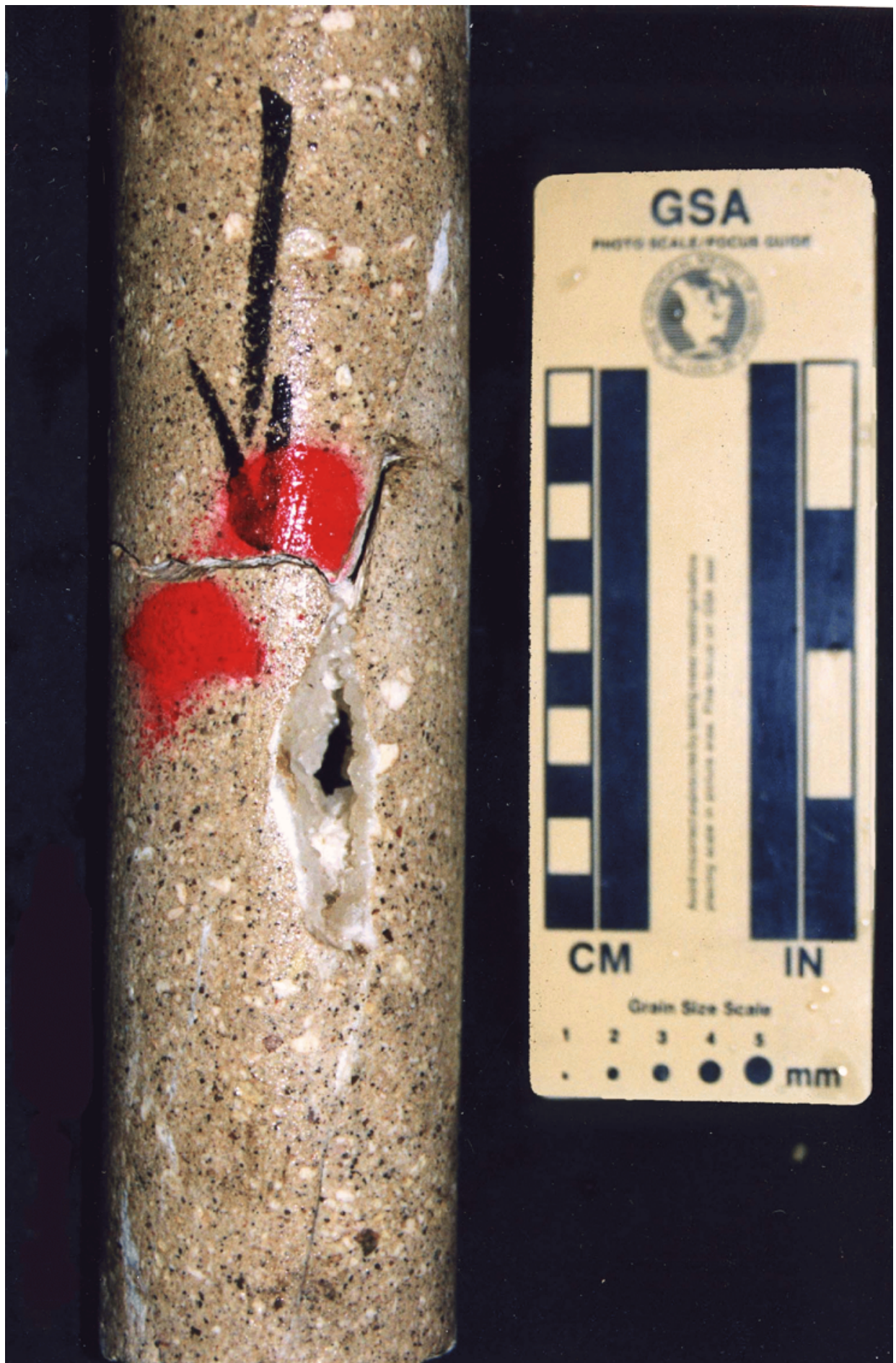

Opening is $1 \mathrm{~cm}$ wide. Note coarsely crystalline calcite that partially fills opening. Red paint indicates core was purposely broken during the boxing process. Black arrow on core indicates down-hole direction. Core is from the 423.2-m (1,388.5-ft) depth in UE-7f. Core was moistened prior to photographing to better reveal details.

Figure 2-12

Fracture with Large, Through-Going Aperture 
Table 2-5

Fracture Width, Aperture, and Openness

\begin{tabular}{||l|c|c|c|c|c||}
\hline \multicolumn{1}{|c|}{ Attribute } & \multicolumn{4}{c|}{ Core Hole } & $\begin{array}{c}\text { Average for } \\
\text { All Four } \\
\text { Holes }\end{array}$ \\
\cline { 2 - 6 } & UE-7f & UE-7az & UE-7ba & UE-7bc & -- \\
\hline \hline $\begin{array}{l}\text { Range of Fracture Widths } \\
\text { (in millimeters) }\end{array}$ & $0.1-10$ & $0.1-10$ & $0.1-5$ & $0.1-10$ & 0.8 \\
\hline $\begin{array}{l}\text { Average Width of Fractures } \\
\text { (in millimeters) }\end{array}$ & 0.8 & 0.9 & 0.9 & 0.7 & - \\
\hline $\begin{array}{l}\text { Range of Aperture Sizes } \\
\text { (in millimeters) }\end{array}$ & $0.3-10$ & $0.1-3$ & $0.1-2$ & $0.3-2$ & 1.1 \\
\hline $\begin{array}{l}\text { Average Aperture Size } \\
\text { (in millimeters) }\end{array}$ & 1.4 & 0.9 & 0.6 & 0.8 & -- \\
\hline $\begin{array}{l}\text { Range of Percent of } \\
\text { Fracture that is Open }\end{array}$ & $0.5-75 \%$ & $1-50 \%$ & $1-25 \%$ & $1-25 \%$ & $10 \%$ \\
\hline $\begin{array}{l}\text { Average Percent of Fracture } \\
\text { that is Open }\end{array}$ & $9 \%$ & $13 \%$ & $10 \%$ & $7 \%$ & \\
\hline \hline
\end{tabular}

\subsection{Fracture Surface Texture}

Most of the fractures have surfaces that are rough or very rough (Figure 1-4). Surface textures of joints appear to be related to the grain size of the unit. Coarser grained units that consist of large pumice and lithic fragments typically have joints with rough fracture surfaces. Coarse-grained bedded tuffs are common in all four holes, which accounts for the high percentage of rough fracture surfaces observed. The surface textures of faults appear to be dependent not only on the grain-size of the unit, but also on the degree of development of the fault surface. Faults in coarsegrained units and with poorly developed slickensides typically have rough fracture surfaces. However, some faults in coarse-grained units have well developed slickensides, and thus have very smooth fracture surfaces.

The texture of fracture surfaces can have a significant affect on ground water flow and radionuclide migration through fractures. For example, rough textures result in more tortuous flow paths along fractures, and increase the surface area of fractures, which could have important implications with regards to sorption of radionuclides. 


\subsection{Secondary Mineral Coatings}

Almost all fractures observed were coated or filled with some type of secondary mineral, with many fractures containing more than one type of secondary mineral (Figure 2-13). Zeolite occurs most often, being observed in 48 percent of the fractures examined (Table 2-6). Zeolite is typically white, chalky to slightly waxy, and very fine-grained (Figure 2-14).

Metallic oxides were the second most common secondary mineral observed. They occur in 37 percent of the fractures examined. The metallic oxides typically occur as thin reddish-brown to black coatings and staining along fracture walls. Although quite common, metallic oxides often occur in minor abundance with other secondary minerals. Iron oxides appeared to be the most common metallic oxide observed with manganese oxide (Figure 2-15) being somewhat less common.

Crystalline quartz was observed in 14 percent of the fractures (Figure 2-16). It is most common

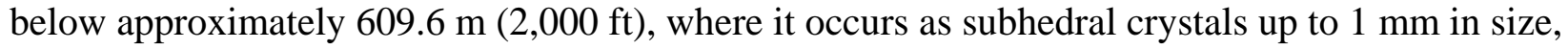
or as very-fine-grained material with a sugary texture. Other secondary minerals observed included calcite, chalcedony, and clay.

The identification of secondary minerals was based solely on visible characteristics of the minerals. No laboratory analyses were performed. 


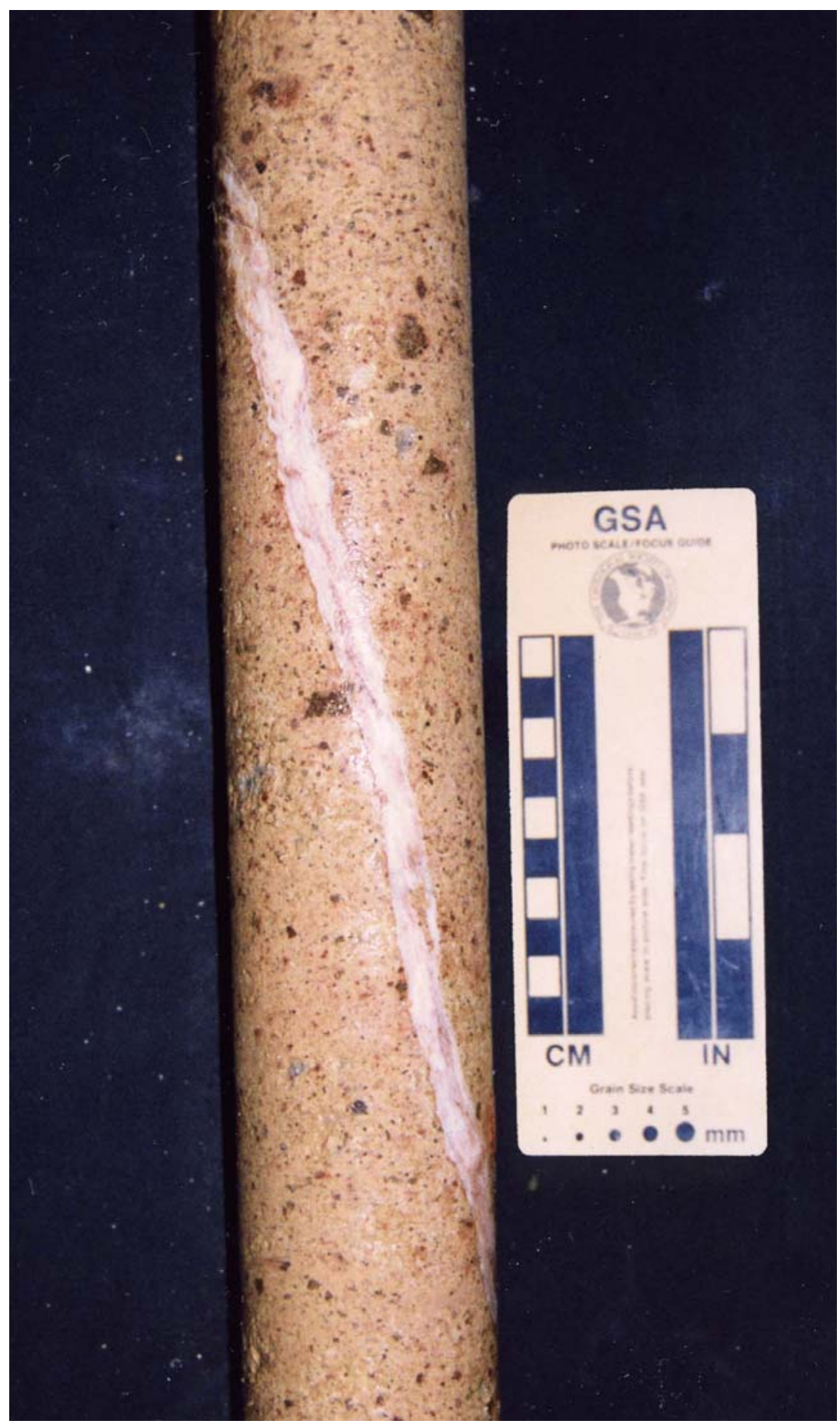

This 1-cm-wide fracture is completely filled with quartz, calcite, and very minor iron oxide (red color). Quartz is the most abundant secondary mineral, and was the first to form in this fracture. Calcite was deposited in lesser amounts within cracks and openings in the quartz probably caused by reactivation of the fracture. Iron oxide is associated with the quartz. Core is from the 776.2-m (2,546.5-ft) depth in UE-7bc. Core was moistened prior to photographing to better reveal details.

Figure 2-13

Fracture Filled with Quartz, Calcite, and Iron Oxide 
Table 2-6

Secondary Minerals Observed Visually in Fractures

\begin{tabular}{||c|c|c|c|c|c||}
\hline \multirow{2}{*}{$\begin{array}{c}\text { Secondary } \\
\text { Mineral }\end{array}$} & \multicolumn{4}{|c||}{ Core Holes } & $\begin{array}{c}\text { Average for } \\
\text { All Four } \\
\text { Holes }\end{array}$ \\
\cline { 2 - 5 } & UE-7f & UE-7az & UE-7ba & UE-7bc & $8 \%$ \\
\hline \hline None & $11 \%$ & $5 \%$ & $6 \%$ & $10 \%$ & $48 \%$ \\
\hline Zeolite & $44 \%$ & $41 \%$ & $58 \%$ & $66 \%$ & $2 \%$ \\
\hline Chalcedony & $1 \%$ & $3 \%$ & $3 \%$ & $3 \%$ & $37 \%$ \\
\hline $\begin{array}{c}\text { Metallic } \\
\text { oxides }\end{array}$ & $44 \%$ & $40 \%$ & $31 \%$ & $14 \%$ & $7 \%$ \\
\hline Calcite & $4 \%$ & $4 \%$ & $13 \%$ & $13 \%$ & $3 \%$ \\
\hline $\begin{array}{c}\text { Fault gouge } \\
\text { Crystalline } \\
\text { quartz }\end{array}$ & $2 \%$ & $6 \%$ & $2 \%$ & $0 \%$ & $14 \%$ \\
\hline Clay & $0 \%$ & $10 \%$ & $9 \%$ & $19 \%$ & $1 \%$ \\
\hline Unknown & $0 \%$ & $4 \%$ & $0 \%$ & $0 \%$ & $1 \%$ \\
\hline \hline
\end{tabular}




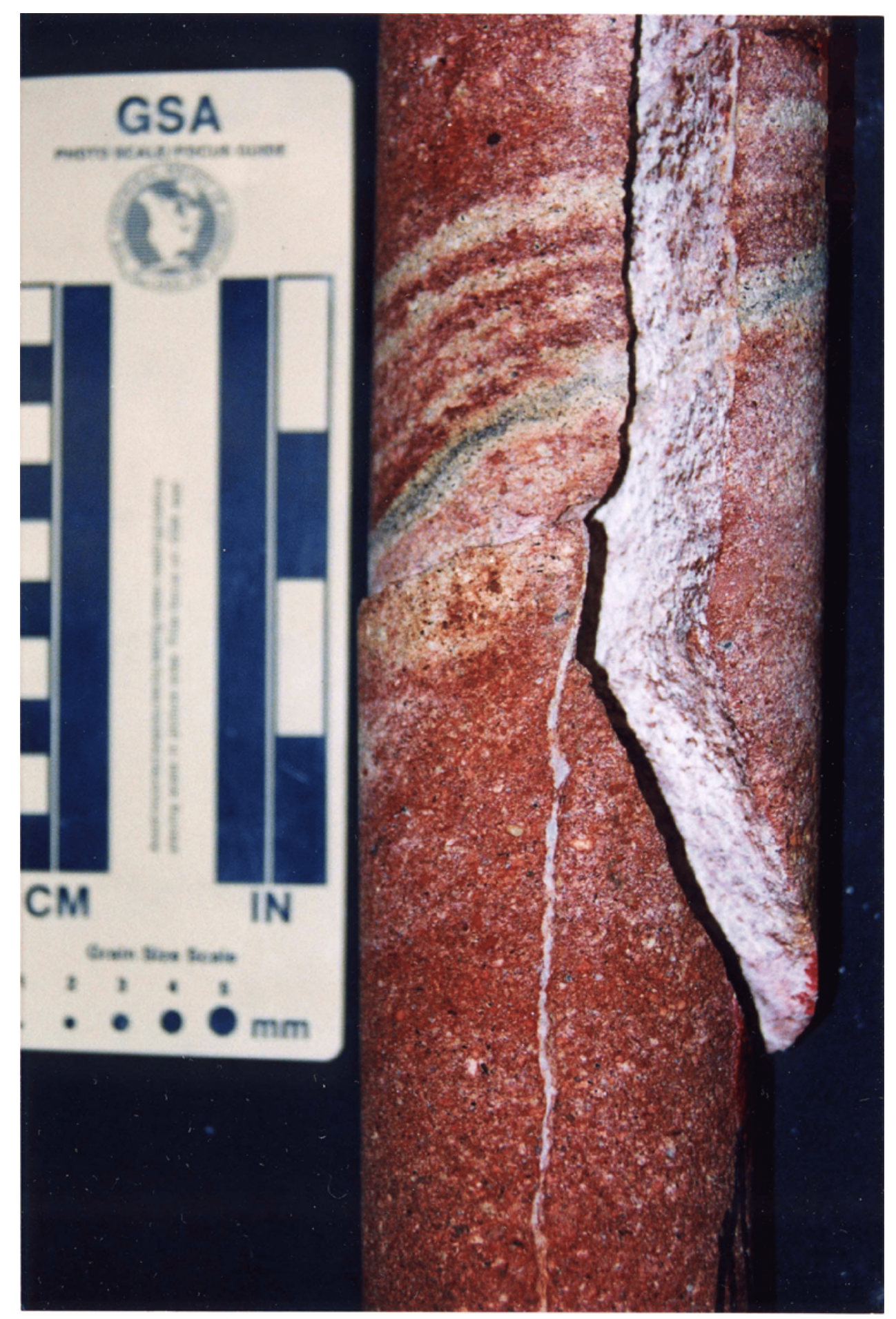

This core segment has broken along part of a vertical zeolite-filled joint. Note very fine-grained, white zeolite filling the fracture and coating the fracture surfaces. Core is from the 495.4-m $(1,625.4-\mathrm{ft})$ depth in hole UE-7bc. Core was moistened prior to photographing to better reveal details.

Figure 2-14 Zeolite-Filled Fracture 


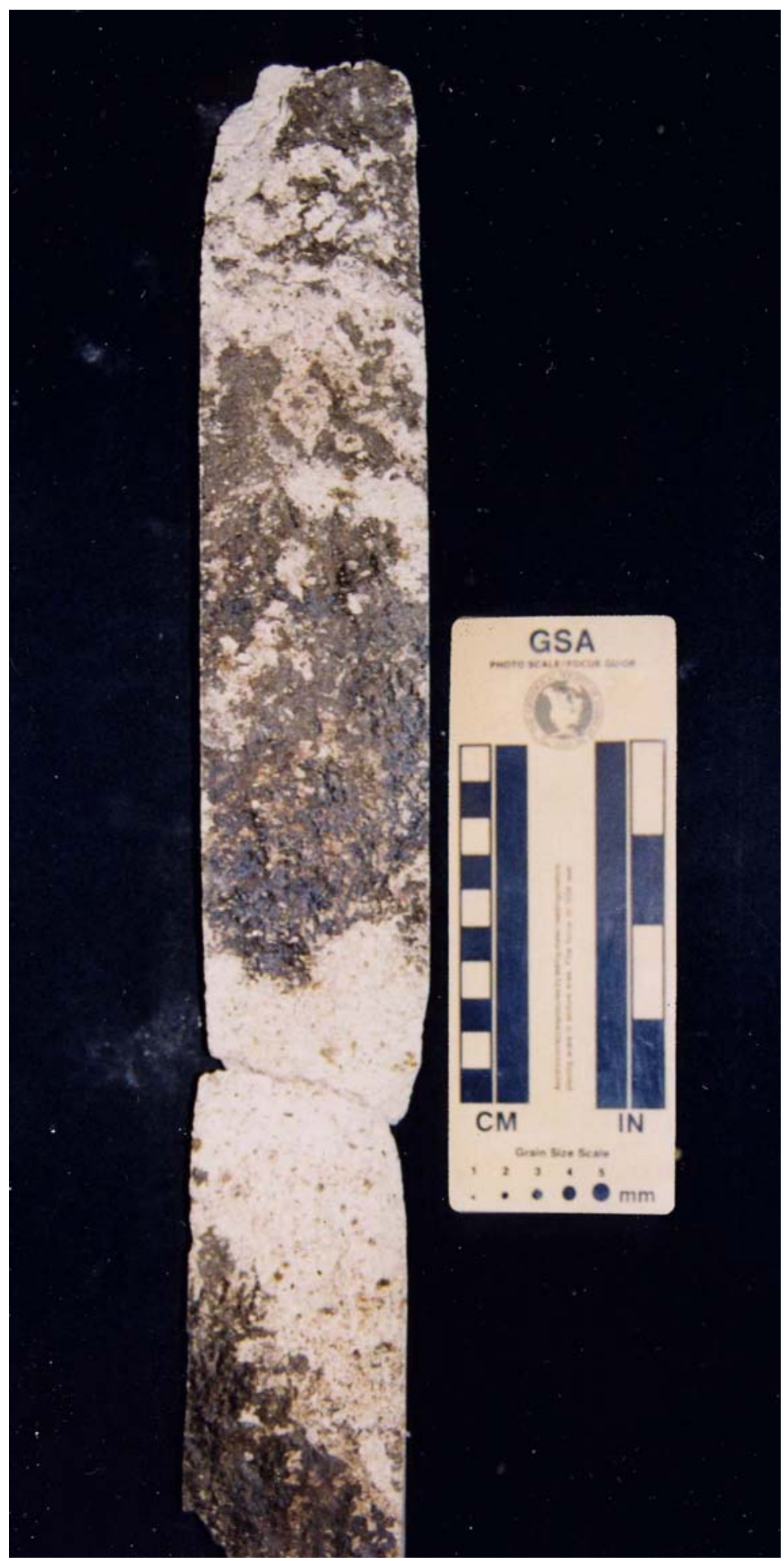

Note the deposit of dark manganese oxide partially coating the surface of this vertical joint. Core is from the 709.0-m (2,326-ft) depth in UE-7bc.

Figure 2-15

Joint Surface Coated with Manganese Oxide 


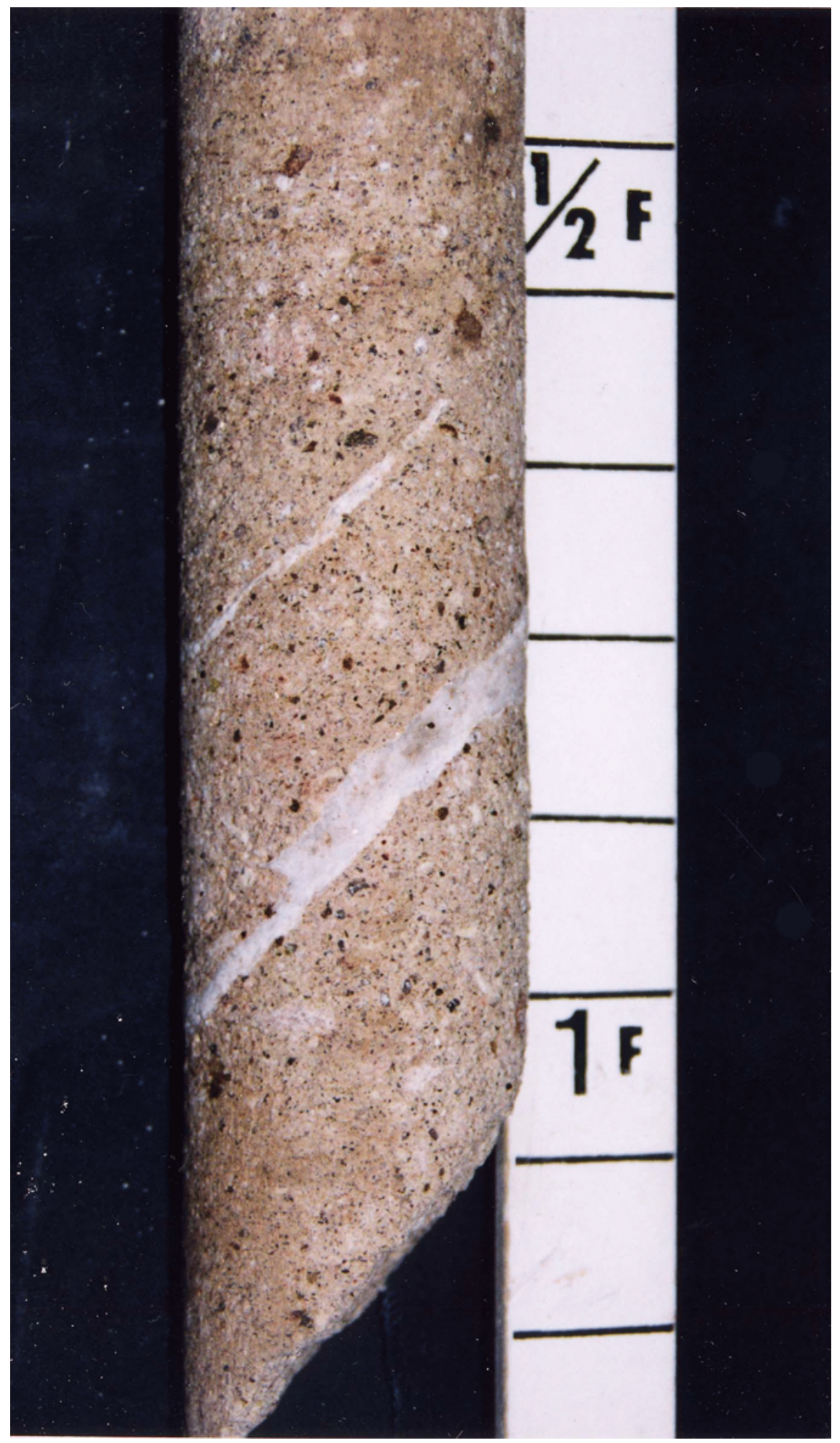

Core is from the 609.9-m (2,001-ft) depth in UE-7az.

Figure 2-16

Joints Completely Filled with Crystalline Quartz 
This page intentionally left blank. 


\subsection{Summary}

Fractures observed in the TCU from four core holes in Area 7 of Yucca Flat consist mostly of joints, with faults accounting for about 28 percent of the fractures observed. Approximately half the fractures were observed to be planar and continuous in shape. Almost 30 percent are discontinuous. The average dip of the fractures is $69^{\circ}$. The density of fractures averages 0.27 fractures per vertical meter of core (0.08 fractures per vertical foot of core). Open fractures, or those observed to have some aperture, average 0.06 fractures per vertical meter of core

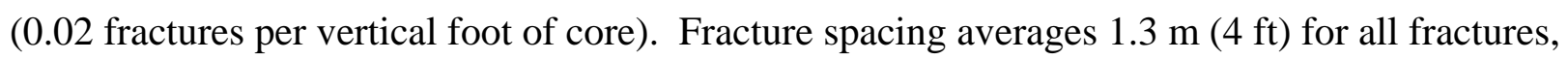
and $5.0 \mathrm{~m}(16 \mathrm{ft})$ for open fractures. Fractures are typically thin, averaging less than $1 \mathrm{~mm}$ in width. Aperture ranges from less than 0.1 to $10 \mathrm{~mm}$ wide, averaging $1.1 \mathrm{~mm}$, and typically was observed as small isolated openings. On average, aperture accounts for only 10 percent of the fracture volume, the rest being completely healed with secondary minerals. Most fracture surfaces have rough to very rough textures. Zeolite is the most common secondary mineral filling, occurring in 48 percent of the fractures. Metallic oxide is the second most common mineral filling, often occurring in minor abundance with other secondary minerals.

The results of this study indicate that the TCU in the central portion of Yucca Flat is poorly fractured. Fracture attributes observed suggest that fractures within the TCU in the vicinity of the four holes do not substantially increase the permeability of the TCU. Because this study presents data for fractures within typical sequences of TCU from the central portion of Yucca Flat, the data and conclusions are probably applicable to other areas of the basin. However, the core holes analyzed in this study are located significant distances (greater than $609.6 \mathrm{~m}$ [2,000 ft]) from major faults. Also, because only natural fractures were examined, fractures that may have formed as a result of underground nuclear testing were not included in the analyses. The potential for increases in permeability due to enhanced fracturing of the TCU beneath Yucca Flat by faulting and underground nuclear detonations is poorly understood (Laczniak et al., 1996).

Because Yucca Flat is an extensional basin, the information in this report may also be applicable to other extensional basins, such as Frenchman Flat. However, outside these basins, in less extended terrain such as that at Rainier and Aqueduct mesas, the TCU may be even less fractured than reported here. 
This page intentionally left blank. 


\subsection{References Cited}

Bechtel Nevada, 2006. A Hydrostratigraphic Model and Alternatives for the Groundwater Flow and Contaminant Transport Model of Corrective Action Unit 97: Yucca Flat-Climax Mine, Lincoln and Nye Counties, Nevada. DOE/NV/11718--1119. Las Vegas, NV.

Drellack, Jr., S. L., L. B. Prothro, K. E. Roberson, B. A. Schier, and E. H. Price, 1997. Analysis of Fractures in Volcanic Cores From Pahute Mesa, Nevada Test Site, DOE/NV/11718--160. Las Vegas, NV.

Ferguson, J. F., A. H. Cogbill, and R. G. Warren, 1994. “A Geophysical-Geological Transect of the Silent Canyon Caldera Complex, Pahute Mesa, Nevada.” Journal of Geophysical Research, v. 99, n. 33, pp. 4,323-4,339.

Frizzell, V. A. and J. Shulters, 1990. Geologic Map of the Nevada Test Site, Southern Nevada, U.S. Geological Survey Miscellaneous Investigation Series Map I-2046, scale 1:100,000. Washington, D.C.

Laczniak, R. J., J. C. Cole, D. A. Sawyer, and D. A. Trudeau, 1996. Summary of Hydrogeologic Controls on the Movement of Groundwater at the Nevada Test Site, Nye County, Nevada, U.S. Geological Survey, Water-Resources Investigations Report 96-4109. Carson City, NV.

Raytheon Services Nevada, 1990. Nevada Test Site Drilling and Mining Summary. Available from National Security Technologies, LLC. Mercury, NV.

Twiss, R. J., and E. M. Moores, 1992. Structural Geology. W. H. Freeman and Company. New York.

Winograd, I. J., and W. Thordarson, 1975. Hydrogeologic and Hydrochemical Framework, South-Central Great Basin, Nevada-California, with Special Reference to the Nevada Test Site, U.S. Geological Survey Professional Paper 712-C. 
This page intentionally left blank. 


\section{Appendix A \\ List of Core Holes in Yucca Flat}


APPENDIX A

Core and Borehole Information for Conventional Core Holes in Yucca Flat (unless otherwise noted all values are in feet)

\begin{tabular}{|c|c|c|c|c|c|c|c|c|c|c|}
\hline \multirow[t]{2}{*}{ Core Hole } & \multicolumn{2}{|c|}{$\begin{array}{l}\text { Core Hole Location (Central } \\
\text { Nevada State Planar } \\
\text { Coordinates, NAD 27) }\end{array}$} & \multirow[t]{2}{*}{$\begin{array}{c}\text { Surface } \\
\text { Elevation } \\
\text { (above mean } \\
\text { sea level) }\end{array}$} & \multirow[t]{2}{*}{$\begin{array}{l}\text { Total } \\
\text { Depth }\end{array}$} & \multicolumn{2}{|c|}{$\begin{array}{l}\text { Depth of Cored } \\
\text { Interval }\end{array}$} & \multirow[t]{2}{*}{$\begin{array}{c}\text { Depth to Top of } \\
\text { Stratigraphic } \\
\text { Unit }\end{array}$} & \multirow[t]{2}{*}{$\begin{array}{c}\text { Stratigraphic } \\
\text { Unit }^{\star}\end{array}$} & \multirow[t]{2}{*}{$\underset{\text { Unit }^{* *}}{\text { Hydrogeologic }}$} & \multirow[t]{2}{*}{$\begin{array}{c}\text { Core } \\
\text { Diameter } \\
\text { (inches) }\end{array}$} \\
\hline & Northing & Easting & & & Top & Bottom & & & & \\
\hline \multirow[t]{3}{*}{ UE1a } & 837000 & 660000 & 4303 & 957 & 510 & 517 & 320 & Tlt & $\mathrm{TCU}$ & 4 \\
\hline & & & & & 820 & 825 & 320 & Tlt & TCU & \\
\hline & & & & & 952 & 957 & 900 & $\mathrm{Pz}$ & $\mathrm{CCU}$ & \\
\hline \multirow[t]{3}{*}{ UE1b } & 837000 & 662000 & 4272 & 1254 & 510 & 530 & 0 & QTa & AA & 4 \\
\hline & & & & & 1154 & 1160 & 760 & $\mathrm{Pz}$ & $\mathrm{CCU}$ & \\
\hline & & & & & 1249 & 1254 & 760 & $\mathrm{Pz}$ & $\mathrm{CCU}$ & \\
\hline \multirow[t]{3}{*}{ UE1c } & 837000 & 666000 & 4206 & 1880 & 510 & 530 & 0 & QTa & AA & 4 \\
\hline & & & & & 1444 & 1454 & 1340 & Tn4 & VTA & \\
\hline & & & & & 1875 & 1880 & 1771 & $\mathrm{Pz}$ & CA & \\
\hline \multirow{2}{*}{ UE1d } & 837700 & 661050 & 4295 & 857 & 510 & 530 & 430 & Tlt & TCU & 3.5 \\
\hline & & & & & 850 & 855 & 750 & $\mathrm{Pz}$ & $\mathrm{CCU}$ & \\
\hline \multirow[t]{5}{*}{ UE1e } & 836500 & 663600 & 4244 & 1704 & 510 & 530 & 0 & QTa & AA & 3.5 \\
\hline & & & & & 663 & 673 & 530 & Tmrl/Th & VTA & \\
\hline & & & & & 1200 & 1205 & 960 & Tn4 & VTA & \\
\hline & & & & & 1570 & 1575 & 1540 & $\mathrm{Pz}$ & CA & \\
\hline & & & & & 1697 & 1702 & 1540 & $\mathrm{Pz}$ & $\mathrm{CCU}$ & \\
\hline \multirow[t]{3}{*}{ UE1f } & 836212 & 661373 & 4277 & 703 & 358 & 363 & 0 & QTa & AA & 3.5 \\
\hline & & & & & 510 & 530 & 0 & QTa & AA & \\
\hline & & & & & 649 & 701 & 560 & $\mathrm{Pz}$ & $\mathrm{CCU}$ & \\
\hline \multirow[t]{4}{*}{ UE1g } & 838500 & 662900 & 4263 & 1442 & 510 & 530 & 0 & $\mathrm{QTa}$ & AA & 3.5 \\
\hline & & & & & 586 & 591 & 530 & $\mathrm{Tmrl} / \mathrm{Th}$ & VTA & \\
\hline & & & & & 707 & 713 & 530 & Tmrl/Th & VTA & \\
\hline & & & & & 1437 & 1442 & 1382 & $\mathrm{Pz}$ & $\mathrm{CCU}$ & \\
\hline UE1h & 820000 & 675000 & 3995 & 3358 & 794 & 798 & 0 & QTa & AA & 3.5 \\
\hline UE1j & 824500 & 673250 & 4040 & 1632 & 1433 & 1444 & 0 & QTa & AA & 3.5 \\
\hline UE1k & 833500 & 677500 & 4053 & 2338 & 2332 & 2338 & 2180 & Tmr & WTA & 3.5 \\
\hline \multirow[t]{2}{*}{ UE1I } & 837000 & 654001 & 4454 & 5339 & 2925 & 2945 & 200 & $\mathrm{Pz}$ & $\mathrm{CCU}$ & 5.25 \\
\hline & & & & & 4206 & 4235 & 200 & $\mathrm{Pz}$ & $\mathrm{CCU}$ & \\
\hline UE1m & 825407 & 657842 & 4478 & 514 & 8.75 & 514 & $?$ & $?$ & $?$ & 1.875 \\
\hline \multirow[t]{2}{*}{ UE1p } & 826269 & 662299 & 4232 & 782 & 580 & 587.2 & 0 & QTa & AA & 2.5 \\
\hline & & & & & 773 & 782 & 773 & $\mathrm{Pz}$ & $\mathrm{CA}$ & \\
\hline $\mathrm{U} 2 \mathrm{a}$ & 879400 & 671951 & 4402 & 760 & 752 & 762 & 0 & QTa & AA & 3.5 \\
\hline $\mathrm{U} 2 \mathrm{~b}$ & 879145 & 672900 & 4384 & 560 & 540 & 548 & 0 & QTa & $\mathrm{AA}$ & 3.5 \\
\hline $\mathrm{U} 2 \mathrm{~g}$ & 875599 & 671950 & 4373 & 760 & 740 & 748 & 0 & QTa & AA & $?$ \\
\hline $\mathrm{U} 2 \mathrm{~h}$ & 875854 & 671000 & 4390 & 560 & 540 & 548 & 0 & QTa & AA & 3.5 \\
\hline \multirow[t]{6}{*}{ U2n\#1 } & 873580 & 672168 & 4353 & 2273 & 200 & 208 & 0 & QTa & AA & 3.5 \\
\hline & & & & & 720 & 728 & 0 & QTa & AA & \\
\hline & & & & & 730 & 735 & 0 & QTa & AA & \\
\hline & & & & & 770 & 778 & 0 & QTa & AA & \\
\hline & & & & & 870 & 878 & 0 & QTa & AA & \\
\hline & & & & & 917 & 925 & 0 & QTa & $\mathrm{AA}$ & \\
\hline U2p\#1 & 874578 & 671829 & 4369 & 1405 & 1290 & 1298 & 0 & QTa & AA & 3.5 \\
\hline
\end{tabular}


APPENDIX A Core and Borehole Information for Conventional Core Holes in Yucca Flat

\begin{tabular}{|c|c|c|c|c|c|c|c|c|c|c|}
\hline \multirow[t]{2}{*}{ Core Hole } & \multicolumn{2}{|c|}{$\begin{array}{l}\text { Core Hole Location (Central } \\
\text { Nevada State Planar } \\
\text { Coordinates, NAD 27) }\end{array}$} & \multirow[t]{2}{*}{$\begin{array}{c}\text { Surface } \\
\text { Elevation } \\
\text { (above mean } \\
\text { sea level) }\end{array}$} & \multirow[t]{2}{*}{$\begin{array}{l}\text { Total } \\
\text { Depth }\end{array}$} & \multicolumn{2}{|c|}{$\begin{array}{l}\text { Depth of Cored } \\
\text { Interval }\end{array}$} & \multirow[t]{2}{*}{$\begin{array}{l}\text { Depth to Top of } \\
\text { Stratigraphic } \\
\text { Unit }\end{array}$} & \multirow[t]{2}{*}{$\begin{array}{c}\text { Stratigraphic } \\
\text { Unit }\end{array}$} & \multirow[t]{2}{*}{$\underset{\text { Unit }^{\star *}}{\text { Hydrogeologic }}$} & \multirow[t]{2}{*}{$\begin{array}{l}\text { Core } \\
\text { Diameter } \\
\text { (inches) }\end{array}$} \\
\hline & Northing & Easting & & & Top & Bottom & & & & \\
\hline \multirow[t]{6}{*}{ U2q\#1 } & 861188 & 678773 & 4195 & 1390 & 1000 & 1008 & 0 & QTa & AA & 3.5 \\
\hline & & & & & 1100 & 1103.4 & 1050 & Tmr & WTA & \\
\hline & & & & & 1103.4 & 1108 & 1050 & Tmr & WTA & \\
\hline & & & & & 1250 & 1256 & 1050 & Tmr & WTA & \\
\hline & & & & & 1300 & 1308 & 1050 & Tmr & WTA & \\
\hline & & & & & 1350 & 1358 & 1050 & Tmr & WTA & \\
\hline \multirow[t]{5}{*}{ U2\#\#1 } & 865500 & 674070 & 4262 & 3342 & 1971 & 1974 & 0 & QTa & $\mathrm{AA}$ & 3.5 \\
\hline & & & & & 2000 & 2009 & 0 & QTa & AA & \\
\hline & & & & & 2600 & 2604 & 2451 & TV & TCU & \\
\hline & & & & & 3336 & 3342 & 2969 & $\mathrm{Tn}$ & TCU & \\
\hline & & & & & & & 3337 & $\mathrm{Pz}$ & CA & \\
\hline U2au & 863020 & 678300 & 4209 & 1405 & 1300 & 1354 & 1181 & Tmr & WTA & 3.5 \\
\hline UE2a\#1 & 864601 & 668200 & 4330 & 2460 & 2260 & 2268 & 2129 & $\mathrm{Pz}$ & $\mathrm{CA}$ & 3.5 \\
\hline \multirow{6}{*}{ UE2s } & 863050 & 657169 & 4583 & 1970 & 611 & 619 & 0 & QTa & AA & 3.5 \\
\hline & & & & & 965 & 973 & 840 & Tmr & VTA & \\
\hline & & & & & 1346 & 1354 & 1339 & Tbg & VTA & \\
\hline & & & & & 1646 & 1654 & 1421 & $\mathrm{Tn}$ & TCU & \\
\hline & & & & & 1847 & 1854 & 1736 & $\mathrm{Pz}$ & CA & \\
\hline & & & & & 1962 & 1970 & 1736 & $\mathrm{Pz}$ & CA & \\
\hline \multirow[t]{3}{*}{ UE2u } & 870198 & 653250 & 4871 & 1473 & 658 & 666 & 522 & Tv & $?$ & $?$ \\
\hline & & & & & 844 & 852 & 732 & Tn & $?$ & \\
\hline & & & & & 1465 & 1473 & 1421 & $\mathrm{Pz}$ & CA & \\
\hline \multirow[t]{3}{*}{ UE2v } & 880035 & 665289 & 4539 & 1668 & 774 & 1660 & $\frac{14-1}{0}$ & QTa & AA & 3.5 \\
\hline & & & & & & & 751 & TV & $?$ & \\
\hline & & & & & & & 1257 & $\mathrm{Pz}$ & $?$ & \\
\hline UE2ad & 867000 & 661001 & 4448 & 866 & 850 & 866 & 781 & $\mathrm{Pz}$ & CA & 3.5 \\
\hline UE2ar & 864593 & 674656 & 4241 & 2351 & 2320 & 2334 & 2110 & Tmr & VTA & 3.5 \\
\hline & $\frac{004050}{867821}$ & $\frac{074000}{674380}$ & $\frac{4 \angle 41}{4272}$ & $\frac{2001}{2328}$ & $\frac{20 \mathrm{OL}}{\text { various } \mathrm{d}}$ & pths & $?$ & $?$ & $?$ & 0.5 \\
\hline \multirow{3}{*}{$\frac{U E Z \text { UWFI }}{\text { UE2ax }}$} & 875218 & 670026 & 4398 & 2920 & 2115 & 2125 & 2070 & Tp & VTA & 3.5 \\
\hline & & & & & 2175 & 2185 & 2070 & $T p$ & VTA & \\
\hline & & & & & 2235 & 2245 & 2070 & $T p$ & VTA & \\
\hline \multirow[t]{2}{*}{ UE2co } & 861900 & 657400 & 4562 & 1921 & 940 & 960 & 869 & $\mathrm{Tp}$ & VTA & 3.5 \\
\hline & & & & & 1905 & 1920.5 & 1772 & $\mathrm{Pz}$ & CA & \\
\hline \multirow[t]{4}{*}{ UE2dj } & 870400 & 670000 & 4341 & 2350 & 1586 & 1590 & 0 & QTa & AA & $?$ \\
\hline & & & & & 1783.5 & 1792.5 & 0 & QTa & AA & \\
\hline & & & & & 1972 & 1984.5 & 0 & QTa & $\mathrm{AA}$ & \\
\hline & & & & & 1990 & 19093 & 0 & QTa & AA & \\
\hline UE2en\#1 & 864600 & 675600 & 4226 & 2500 & 2245 & 2252.3 & 2149 & $\mathrm{Tp}$ & $?$ & 3 \\
\hline UE2ep & 863550 & 674950 & 4226 & 2700 & 2240 & 2257 & 2047 & Tmr & VTA & 3 \\
\hline Grav.H\#1 & 873000 & 662700 & 4440 & 145 & 120 & 145 & 0 & QTa & AA & 2.155 \\
\hline & & & & & & & 144 & $\mathrm{Pz}$ & CA & \\
\hline TH3-9 & 838989 & 697901 & 4176 & 1953 & 1945 & 1953 & 1890 & $\mathrm{Pz}$ & CA & 4 \\
\hline U 3ah\#1 & 836312 & 686479 & 4021 & 1215 & 1135 & 1200 & 0 & QTa & AA & 3.5 \\
\hline U Jah \#1 & $\frac{000034}{83636}$ & $\frac{000415}{686475}$ & $\frac{40<1}{4020}$ & $\frac{1210}{1260}$ & $\frac{1105}{1135}$ & $\frac{1200}{1175}$ & 0 & QTa & AA & $\frac{3.5}{3.5}$ \\
\hline U 3ah\#3 & 836386 & 686471 & 4020 & 1260 & 1190 & 1200 & 0 & QTa & AA & 3.5 \\
\hline U 3ai\#2 & 835650 & 685504 & 4020 & 1215 & 1155 & 1200 & 0 & QTa & AA & 3.5 \\
\hline U Jak & $\frac{850000}{835310}$ & $\frac{685004}{687177}$ & $\frac{4020}{4014}$ & $\frac{1215}{1215}$ & $\frac{1150}{1200}$ & $\frac{1200}{1210}$ & $\frac{0}{0}$ & QTa & AA & $\frac{3.5}{3.5}$ \\
\hline U-3ak-1 & 835335 & 687177 & 4014 & 1252 & 426 & 468 & 0 & QTa & AA & $?$ \\
\hline U-3ak-2 & 835370 & 687177 & 4014 & 1250 & 1135 & 1200 & 0 & QTa & AA & 3.5 \\
\hline U Jams & $\frac{030310}{84321}$ & $\frac{007111}{685645}$ & $\frac{4014}{4071}$ & $\frac{1200}{1620}$ & 1425 & $\frac{1200}{1428}$ & 0 & QTa & AA & ?.0 \\
\hline TH3-E & 839989 & 696001 & 4172 & 2620 & 394 & 1500 & 0 & QTa & AA & 2.155 \\
\hline
\end{tabular}


APPENDIX A Core and Borehole Information for Conventional Core Holes in Yucca Flat

\begin{tabular}{|c|c|c|c|c|c|c|c|c|c|c|}
\hline \multirow[t]{2}{*}{ Core Hole } & \multicolumn{2}{|c|}{$\begin{array}{l}\text { Core Hole Location (Central } \\
\text { Nevada State Planar } \\
\text { Coordinates, NAD 27) }\end{array}$} & \multirow[t]{2}{*}{$\begin{array}{l}\text { Surface } \\
\text { Elevation } \\
\text { (above mean } \\
\text { sea level) }\end{array}$} & \multirow[t]{2}{*}{$\begin{array}{l}\text { Total } \\
\text { Depth }\end{array}$} & \multicolumn{2}{|c|}{$\begin{array}{l}\text { Depth of Cored } \\
\text { Interval }\end{array}$} & \multirow[t]{2}{*}{$\begin{array}{l}\text { Depth to Top of } \\
\text { Stratigraphic } \\
\text { Unit }\end{array}$} & \multirow[t]{2}{*}{$\begin{array}{c}\text { Stratigraphic } \\
\text { Unit }^{*}\end{array}$} & \multirow[t]{2}{*}{$\begin{array}{c}\text { Hydrogeologic } \\
\text { Unit }^{\star \star}\end{array}$} & \multirow[t]{2}{*}{$\begin{array}{l}\text { Core } \\
\text { Diameter } \\
\text { (inches) }\end{array}$} \\
\hline & Northing & Easting & & & Top & Bottom & & & & \\
\hline & & & & & & & 450 & Tmr & WTA & \\
\hline & & & & & & & 750 & $\mathrm{Tmrl} / \mathrm{Th}$ & VTA & \\
\hline & & & & & & & 1151 & Tbgb & VTA & \\
\hline & & & & & & & 1159 & $\mathrm{Tn} 4$ & TCU & \\
\hline U 3an\#3 & 843221 & 683662 & 4061 & 3555 & 3545 & 3555 & 3230 & $\mathrm{Pz}$ & $C A$ & 3.5 \\
\hline \multirow[t]{12}{*}{ U 3cn\#5 } & 841255 & 687998 & 4012 & 3030 & 90 & 3030 & 0 & QTa & AA & 3.5 \\
\hline & & & & & & & 925 & Tma & VTA & \\
\hline & & & & & & & 955 & Tmr & VTA & \\
\hline & & & & & & & 1165 & $\mathrm{Tmrl} / \mathrm{Th}$ & TCU & \\
\hline & & & & & & & 1395 & Twlb & TCU & \\
\hline & & & & & & & 1430 & Tc & TCU & \\
\hline & & & & & & & 1655 & Tn4 & TCU & \\
\hline & & & & & & & 1801 & Tn4E & TCU & \\
\hline & & & & & & & 2102 & Tor & TCU & \\
\hline & & & & & & & 2250 & Tot & TCU & \\
\hline & & & & & & & 2685 & TIt & TCU & \\
\hline & & & & & & & 2821 & $\mathrm{Pz}$ & CA & \\
\hline \multirow[t]{3}{*}{ UE3eh\#1 } & 843514 & 688051 & 4093 & 1750 & 1424 & 1655 & 1175 & $\mathrm{Tmrl} / \mathrm{Th}$ & TCU & $?$ \\
\hline & & & & & & & 1434 & Tbgb & TCU & \\
\hline & & & & & & & 1444 & Tn4 & TCU & \\
\hline $\mathrm{U}-3 \mathrm{ev}-1$ & 839200 & 698000 & 4189 & 1100 & 0 & 150 & 0 & QTa & AA & 2.155 \\
\hline U 3fom1 & 827599 & 687950 & 3981 & 1800 & 1447 & 1546.5 & 1440 & Tmr & WTA & \\
\hline U3ge Ex.\#1 & 825039 & 681718 & 3988 & 980 & 670 & 930 & 630 & Tmr & WTA & 5.25 \\
\hline U3ge Ex.\#2 & 825306 & 682007 & 3988 & 656 & 645 & 654 & 630 & Tmr & WTA & 4 \\
\hline U3gi Ex.\#1 & 831000 & 688349 & 3992 & 1075 & 775 & 1021 & 0 & $\mathrm{QTa}$ & AA & 3 \\
\hline \multirow[t]{2}{*}{ U3gs Ex.\#2 } & 824931 & 697035 & 4009 & 950 & 773 & 900 & 770 & Th & VTA/TCU & 3.5 \\
\hline & & & & & & & 883 & Twlb & TCU & \\
\hline U 3hc & 832700 & 689500 & 4000 & 663 & 660 & 663 & 0 & QTa & AA & $?$ \\
\hline U 3hd\#1 & 831664 & 690565 & 3996 & 1560 & 1540 & 1560 & 1440 & Tmr & WTA & $?$ \\
\hline U 3he & 829100 & 688900 & 3984 & 952 & 950 & 952 & 0 & QTa & AA & $?$ \\
\hline U 3hp & 821000 & 687800 & 3960 & 1300 & 1300 & 1303 & 0 & QTa & $\mathrm{AA}$ & $?$ \\
\hline U 3hq & 824000 & 685800 & 3970 & 1100 & 1100 & 1103 & 0 & QTa & AA & $?$ \\
\hline U $3 \mathrm{hr}$ & 821800 & 683000 & 3970 & 942 & 941 & 942 & 890 & Tmr & $?$ & $?$ \\
\hline U 3hs & 824426 & 689849 & 3968 & 427 & 425 & 426 & 0 & QTa & AA & $?$ \\
\hline \multirow{2}{*}{ U-3ht Ex.\#1 } & 824165 & 690299 & 3970 & 1115 & 460 & 471.5 & 0 & QTa & AA & \\
\hline & & & & & 855.5 & 1106 & 0 & QTa & AA & 3 \\
\hline U 3hu & 823726 & 689500 & 3966 & 1078 & 1075 & 1078 & 0 & QTa & AA & $?$ \\
\hline U 3hv & 824031 & 688814 & 3968 & 852 & 850 & 850.5 & 0 & QTa & AA & $?$ \\
\hline$U 3 h x$ & 820002 & 689000 & 3955 & 1052 & 1050 & 1052 & 0 & QTa & AA & $?$ \\
\hline U3hx Ex\#1 & 820210 & 688950 & 3955 & 1200 & 850 & 1150 & $?$ & $?$ & $?$ & 5 \\
\hline \begin{tabular}{|l|} 
U $3 \mathrm{hz} \# 1$ \\
\end{tabular} & 827558 & 689075 & 3981 & 1460 & 1240 & 1401 & 1235 & Tmr & WTA & $?$ \\
\hline \multirow{2}{*}{ U 3ja } & 821949 & 690321 & 3959 & 1120 & 1040 & 1043 & 1040 & Tma & VTA & $?$ \\
\hline & & & & & 1120 & 1123 & 1070 & Tmr & VTA & \\
\hline U 3jb & 822381 & 689778 & 3961 & 1360 & 1360 & 1363 & 1170 & Tmr & WTA & $?$ \\
\hline$U-3 j c$ Ex\#1 & 822226 & 689051 & 3961 & 1150 & 850 & 1097 & $?$ & $?$ & $?$ & $?$ \\
\hline \multirow[t]{2}{*}{ U 3jd } & 821897 & 689965 & 3960 & 530 & 400 & 401 & 0 & QTa & AA & $?$ \\
\hline & & & & & 528 & 530 & 0 & QTa & $\mathrm{AA}$ & \\
\hline \begin{tabular}{|l} 
U-3je Ex\#1 \\
\end{tabular} & 829000 & 686050 & 3986 & 1200 & 850 & 1136 & $?$ & $?$ & $?$ & $?$ \\
\hline \multirow{2}{*}{ U $3 \mathrm{jh}$} & 817400 & 687650 & 3948 & 1424 & 1200 & 1203 & 0 & QTa & AA & $?$ \\
\hline & & & & & 1410 & 1413 & 0 & QTa & $\mathrm{AA}$ & \\
\hline U 3ji & 816500 & 687650 & 3945 & 973 & 970 & 973 & 0 & QTa & $A A$ & $?$ \\
\hline U3ii & 816910 & 688225 & 3946 & 573 & 570 & 573 & 0 & QTa & $\mathrm{AA}$ & $?$ \\
\hline
\end{tabular}


APPENDIX A

Core and Borehole Information for Conventional Core Holes in Yucca Flat

(unless otherwise noted all values are in feet)

\begin{tabular}{|c|c|c|c|c|c|c|c|c|c|c|}
\hline \multirow[t]{2}{*}{ Core Hole } & \multicolumn{2}{|c|}{$\begin{array}{l}\text { Core Hole Location (Central } \\
\text { Nevada State Planar } \\
\text { Coordinates, NAD 27) }\end{array}$} & \multirow[t]{2}{*}{$\begin{array}{c}\text { Surface } \\
\text { Elevation } \\
\text { (above mean } \\
\text { sea level) }\end{array}$} & \multirow[t]{2}{*}{$\begin{array}{l}\text { Total } \\
\text { Depth }\end{array}$} & \multicolumn{2}{|c|}{$\begin{array}{l}\text { Depth of Cored } \\
\text { Interval }\end{array}$} & \multirow[t]{2}{*}{$\begin{array}{c}\text { Depth to Top of } \\
\text { Stratigraphic } \\
\text { Unit }\end{array}$} & \multirow[t]{2}{*}{$\begin{array}{c}\text { Stratigraphic } \\
\text { Unit* }^{*}\end{array}$} & \multirow[t]{2}{*}{$\begin{array}{c}\text { Hydrogeologic } \\
\text { Unit }^{* *}\end{array}$} & \multirow[t]{2}{*}{$\begin{array}{l}\text { Core } \\
\text { Diamete } \\
\text { (inches) }\end{array}$} \\
\hline & Northing & Easting & & & Top & Bottom & & & & \\
\hline U 3jq & 843200 & 694000 & 4175 & 1903 & 1900 & 1902 & 1845 & Ton1 & TCU & $?$ \\
\hline \multirow[t]{3}{*}{ U 3jq\#1 } & 843201 & 694050 & 4175 & 2224 & 1600 & 1951 & 1260 & Tbgb & TCU & 4 \\
\hline & & & & & & & 1706 & Toy & TCU & \\
\hline & & & & & & & 1845 & Ton1 & TCU & \\
\hline U3js\#1 & 821600 & 688750 & 3959 & 1200 & 981 & 1132 & $?$ & $?$ & $?$ & 5.25 \\
\hline U3ji\#1 & 820975 & 689050 & 3957 & 950 & 700 & 890 & $?$ & $?$ & $?$ & 5 \\
\hline \multirow[t]{2}{*}{ U3ju } & 827880 & 689850 & 3979 & 553 & 420 & 423 & 0 & QTa & AA & $?$ \\
\hline & & & & & 550 & 553 & 0 & QTa & $\mathrm{AA}$ & \\
\hline \multirow[t]{2}{*}{ U3jw } & 827480 & 689890 & 3977 & 553 & 420 & 423 & 0 & QTa & AA & $?$ \\
\hline & & & & & 550 & 553 & 0 & QTa & $\mathrm{AA}$ & \\
\hline U3jx & 820779 & 689790 & 3957 & 503 & 500 & 503 & 0 & QTa & AA & $?$ \\
\hline U3ka & 831499 & 688900 & 3995 & 1160 & 1160 & 1163 & 0 & QTa & AA & $?$ \\
\hline \multirow{2}{*}{ U3kb } & 828201 & 686350 & 3983 & 1510 & 1310 & 1312 & 0 & QTa & $\mathrm{AA}$ & $?$ \\
\hline & & & & & 1510 & 1512 & 0 & QTa & AA & \\
\hline U3kc & 820400 & 687497 & 3957 & 1112 & 1110 & 1112 & 0 & QTa & AA & $?$ \\
\hline U3kf & 839600 & 687250 & 4047 & 663 & 660 & 663 & 0 & QTa & AA & $?$ \\
\hline U3kg & 820000 & 691400 & 4002 & 660 & 662 & 664 & 0 & QTa & AA & $?$ \\
\hline U3ki & 822001 & 685499 & 3963 & 1150 & 1150 & 1153 & 0 & QTa & $A A$ & $?$ \\
\hline U3ko & 843700 & 686600 & 4077 & 1400 & 1400 & 1403 & 1285 & Tc & TCU & $?$ \\
\hline U3kp & 827098 & 687302 & 3979 & 1410 & 1410 & 1412 & 0 & QTa & $\mathrm{AA}$ & $?$ \\
\hline U3ks & 825000 & 692300 & 3966 & 1615 & 1610 & 1613 & 1430 & Tcb & TCU & $?$ \\
\hline U3kt & 831500 & 682000 & 4005 & 1510 & 1510 & 1512 & 0 & QTa & AA & $?$ \\
\hline \multirow[t]{2}{*}{ UE3a } & 826000 & 698000 & 4035 & 1706 & 419 & 425 & 190 & Tmr & WTA & 3.5 \\
\hline & & & & & 1105 & 1110 & 910 & Twlb & TCU & \\
\hline \multirow[t]{3}{*}{ UE3as } & 826000 & 698000 & 4035 & 1706 & 210 & 220 & 190 & Tmr & WTA & 3.5 \\
\hline & & & & & 931 & 936 & 910 & Twlb & $?$ & \\
\hline & & & & & 1300 & 1305 & 910 & Twlb & $\mathrm{TCU}$ & \\
\hline UE3b & 843950 & 682000 & 4080 & 780 & 770 & 780 & 610 & $\mathrm{Tmr}$ & VTA & 2.155 \\
\hline \multirow[t]{5}{*}{ UE3e\#2 } & 844938 & 679983 & 4081 & 2372 & 1950 & 2372 & 1695 & $\mathrm{Tmrl} / \mathrm{Th}$ & TCU & 2.5 \\
\hline & & & & & & & 1984 & Twlb & TCU & \\
\hline & & & & & & & 2095 & Tc & TCU & \\
\hline & & & & & & & 2191 & Tcb & TCU & \\
\hline & & & & & & & 2364 & Tn4 & TCU & \\
\hline $\mathrm{U} 4 \mathrm{a}$ & 858603 & 679099 & 4169 & 3152 & 3152 & 3153 & 3060 & $\mathrm{Pz}$ & CA & $?$ \\
\hline \multirow{4}{*}{ U4d\#1 } & 857531 & 679038 & 4167 & 2536 & 1883 & 2480 & 1685 & Tc & TCU & 3.5 \\
\hline & & & & & & & 1907 & Tbgb & TCU & \\
\hline & & & & & & & 1946 & $\mathrm{Tn} 4$ & TCU & \\
\hline & & & & & & & 2353 & Tn3 & TCU & \\
\hline \multirow[t]{2}{*}{ U4e } & 858201 & 678000 & 4173 & 3353 & 2426 & 2428 & 2245 & Tn4 & TCU & $?$ \\
\hline & & & & & 3343 & 3353 & 3265 & $\mathrm{Pz}$ & CA & \\
\hline U4e\#1 & 858200 & 677550 & 4178 & 3240 & 3230 & 3240 & 3230 & $\mathrm{Pz}$ & $\mathrm{CA}$ & $?$ \\
\hline Sidetrack & & & 4178 & 3259 & 3245 & 3259 & 3230 & $\mathrm{Pz}$ & $\mathrm{CA}$ & $?$ \\
\hline U4h & 859600 & 678500 & 4175 & 2400 & 2400 & 2401 & 2295 & Ton2 & $\mathrm{TCU}$ & $?$ \\
\hline
\end{tabular}


APPENDIX A

Core and Borehole Information for Conventional Core Holes in Yucca Flat (unless othenwise noted all values are infeet)

\begin{tabular}{|c|c|c|c|c|c|c|c|c|c|c|}
\hline \multirow[t]{2}{*}{ Core Hole } & \multicolumn{2}{|c|}{$\begin{array}{l}\text { Core Hole Location (Central } \\
\text { Nevada State Planar } \\
\text { Coordinates, NAD 27) }\end{array}$} & \multirow[t]{2}{*}{$\begin{array}{c}\text { Surface } \\
\text { Elevation } \\
\text { (above mean } \\
\text { sea level) }\end{array}$} & \multirow[t]{2}{*}{$\begin{array}{l}\text { Total } \\
\text { Depth }\end{array}$} & \multicolumn{2}{|c|}{$\begin{array}{l}\text { Depth of Cored } \\
\text { Interval }\end{array}$} & \multirow[t]{2}{*}{$\begin{array}{c}\text { Depth to Top of } \\
\text { Stratigraphic } \\
\text { Unit }\end{array}$} & \multirow[t]{2}{*}{$\begin{array}{c}\text { Stratigraphic } \\
\text { Unit }^{*}\end{array}$} & \multirow[t]{2}{*}{$\begin{array}{c}\text { Hydrogeologic } \\
\text { Unit }^{* *}\end{array}$} & \multirow[t]{2}{*}{$\begin{array}{c}\text { Core } \\
\text { Diamete } \\
\text { (inches) }\end{array}$} \\
\hline & Northing & Easting & & & Top & Bottom & & & & \\
\hline \multirow[t]{13}{*}{ UE4a } & 856041 & 679741 & 4155 & 3028 & 873 & 3013 & 750 & Tmr & VTA & 3.5 \\
\hline & & & & & & & 1668 & Tbgb & TCU & \\
\hline & & & & & & & 1696 & Tn4 & TCU & \\
\hline & & & & & & & 2087 & Tn3 & TCU & \\
\hline & & & & & & & 2166 & Tn3bc & TCU & \\
\hline & & & & & & & 2321 & Tub & TCU & \\
\hline & & & & & & & 2333 & Ton2 & TCU & \\
\hline & & & & & & & 2695 & Tot & TCU & \\
\hline & & & & & & & 2885 & TV & TCU & \\
\hline & & & & & & & 2990 & Tlt & TCU & \\
\hline & & & & & 2387 & 2900 & 1973 & Tn4 & TCU & \\
\hline & & & & & & & 2845 & $\mathrm{Pz}$ & $\mathrm{CA}$ & \\
\hline & & & & & 3055 & 3153 & 2845 & $\mathrm{Pz}$ & $\mathrm{CA}$ & \\
\hline \multirow[t]{7}{*}{ UE4f } & 851591 & 679126 & 4129 & 3593 & 2995 & 3593 & 2495 & Tn3bc & TCU & 4 \\
\hline & & & & & & & 3005 & Tor & TCU & \\
\hline & & & & & & & 3050 & TV & TCU & \\
\hline & & & & & & & 3140 & Tot & TCU & \\
\hline & & & & & & & 3185 & TV & TCU & \\
\hline & & & & & & & 3465 & Tit & TCU & \\
\hline & & & & & & & 3515 & $\mathrm{Pz}$ & $\mathrm{CA}$ & \\
\hline \multirow[t]{9}{*}{ UE4g\#2 } & 856600 & 679549 & 4152 & 2452 & 1494 & 2452 & 1210 & Tmrl/Th & VTA & 1.875 \\
\hline & & & & & & & 1500 & Twlb & VTA & \\
\hline & & & & & & & 1540 & Tc & TCU & \\
\hline & & & & & & & 1710 & Tbgb & TCU & \\
\hline & & & & & & & 1747 & $\operatorname{Tn} 4$ & TCU & \\
\hline & & & & & & & 2003 & Tn4E & TCU & \\
\hline & & & & & & & 2100 & Tn3 & TCU & \\
\hline & & & & & & & 2369 & Tub & TCU & \\
\hline & & & & & & & 2376 & Ton2 & TCU & \\
\hline \multirow[t]{7}{*}{ UE4t } & 855565 & 680350 & 4144 & 1993 & 728 & 930 & 555 & Tmr & WTA & 0.75 \\
\hline & & & & & 1280 & 1390 & 1240 & Twlb & TCU & \\
\hline & & & & & & & 1290 & Tc & TCU & \\
\hline & & & & & 1529 & 1530 & 1480 & Tn4 & TCU & \\
\hline & & & & & 1852 & 1870 & 1760 & Tn4E & TCU & \\
\hline & & & & & 1927 & 1992 & 1910 & Tn3bc & TCU & \\
\hline & & & & & 2029 & 2031 & 1910 & Tn $3 b c$ & TCU & \\
\hline \multirow[t]{2}{*}{ UE4ab } & 856750 & 672450 & 4201 & 2650 & 1202 & 1210 & 1030 & Tmr & TCU & $?$ \\
\hline & & & & & 2640 & 2650 & 2549 & $\mathrm{Pz}$ & CA & \\
\hline UE4ac & 855950 & 659250 & 4271 & 1677 & 1304 & 1314 & 1175 & $\mathrm{Tn}$ & $\mathrm{CA}$ & \\
\hline \multirow[t]{3}{*}{ UE4ah } & 850000 & 674000 & 4142 & 2851 & 1632 & 1662 & 1512 & Tma & VTA & 3 \\
\hline & & & & & 2285 & 2315 & 2146 & Tc & TCU & \\
\hline & & & & & 2841 & 2849 & 2785 & $\mathrm{Pz}$ & $\mathrm{CA}$ & \\
\hline \multirow[t]{2}{*}{ UE4al } & 848700 & 672570 & 4155 & 2187 & 1784 & 1990 & 1670 & $\mathrm{Pz}$ & CA & 3.5 \\
\hline & & & & & 2057 & 2173 & 1670 & $\mathrm{Pz}$ & $\mathrm{CA}$ & \\
\hline
\end{tabular}


APPENDIX A

Core and Borehole Information for Conventional Core Holes in Yucca Flat (unloss otherwise not all values are in feet

\begin{tabular}{|c|c|c|c|c|c|c|c|c|c|c|}
\hline \multirow[t]{2}{*}{ Core Hole } & \multicolumn{2}{|c|}{$\begin{array}{l}\text { Core Hole Location (Central } \\
\text { Nevada State Planar } \\
\text { Coordinates, NAD 27) }\end{array}$} & \multirow[t]{2}{*}{$\begin{array}{c}\text { Surface } \\
\text { Elevation } \\
\text { (above mean } \\
\text { sea level) }\end{array}$} & \multirow[t]{2}{*}{$\begin{array}{l}\text { Total } \\
\text { Depth }\end{array}$} & \multicolumn{2}{|c|}{$\begin{array}{l}\text { Depth of Cored } \\
\text { Interval }\end{array}$} & \multirow[t]{2}{*}{$\begin{array}{c}\text { Depth to Top of } \\
\text { Stratigraphic } \\
\text { Unit }\end{array}$} & \multirow[t]{2}{*}{$\begin{array}{c}\text { Stratigraphic } \\
\text { Unitt }^{*}\end{array}$} & \multirow[t]{2}{*}{$\begin{array}{c}\text { Hydrogeologic } \\
\text { Unit }^{* *}\end{array}$} & \multirow[t]{2}{*}{$\begin{array}{l}\text { Core } \\
\text { Diameter } \\
\text { (inches) }\end{array}$} \\
\hline & Northing & Easting & & & Top & Bottom & & & & \\
\hline $\mathrm{D} \mid \# 1$ & $?$ & $?$ & $?$ & $?$ & 0 & 200 & 0 & $\mathrm{Pz}$ & $?$ & 2.155 \\
\hline $\mathrm{Dl} 2$ & $?$ & $?$ & $?$ & $?$ & 12 & 53 & 11 & $\mathrm{Pz}$ & $?$ & $?$ \\
\hline $\mathrm{Dl} \# 3$ & $?$ & $?$ & $?$ & $?$ & 4 & 160 & 1 & $\mathrm{Pz}$ & $?$ & $?$ \\
\hline Dl\#4 & $?$ & $?$ & $?$ & $?$ & 22 & 200 & 21 & $\mathrm{Pz}$ & $?$ & $?$ \\
\hline Dl\#6 & $?$ & $?$ & $?$ & $?$ & 2 & 96 & 2 & $\mathrm{Pz}$ & $?$ & $?$ \\
\hline Dl\#7 & $?$ & $?$ & $?$ & $?$ & 10 & 106 & $?$ & $?$ & $?$ & $?$ \\
\hline DI\#8 & $?$ & $?$ & $?$ & $?$ & 1 & 200 & $?$ & $?$ & $?$ & $?$ \\
\hline DI\#99 & $?$ & $?$ & $?$ & $?$ & 0 & 100 & $?$ & $?$ & $?$ & $?$ \\
\hline Dl\#10 & $?$ & $?$ & $?$ & $?$ & 0 & 200 & $?$ & $?$ & $?$ & $?$ \\
\hline DI\#12 & $?$ & $?$ & $?$ & $?$ & 0 & 141 & $?$ & $?$ & $?$ & $?$ \\
\hline U6b & 810000 & 678450 & 3932 & 429 & 427 & 429 & 0 & QTa & AA & $?$ \\
\hline \multirow[t]{2}{*}{ UE6d } & 814000 & 677500 & 3947 & 3896 & 1100 & 1111 & 0 & QTa & AA & 3.5 \\
\hline & & & & & 3886 & 3896 & 3810 & Ton1 & $\mathrm{TCU}$ & \\
\hline \multirow[t]{7}{*}{ UE6d\#2 } & 813500 & 693505 & 3932 & 1487 & 817 & 1487 & 680 & Tmr & WTA & 2.5 \\
\hline & & & & & & & 990 & $\mathrm{Tmrl} / \mathrm{Th}$ & VTATCU & \\
\hline & & & & & & & 995 & $\mathrm{Tpc}$ & TCU & \\
\hline & & & & & & & 1086 & Tpt & WTA & \\
\hline & & & & & & & 1364 & Th & TCU & \\
\hline & & & & & & & 1416 & Twlb & TCU & \\
\hline & & & & & & & 1478 & Tc & TCU & \\
\hline \multirow[t]{8}{*}{ UE6e } & 814000 & 688200 & 3936 & 4209 & 133 & 1384 & 0 & QTa & AA & 4 \\
\hline & & & & & & & 1368 & Tmab & VTA & \\
\hline & & & & & 1460 & 1478 & 1398 & Tmr & WTA & \\
\hline & & & & & 1748 & 1762 & 1745 & Tpc & TCU & \\
\hline & & & & & 1885 & 1895 & 1878 & Tpt & WTA & \\
\hline & & & & & 2050 & 2060 & 1878 & Tpt & WTA & \\
\hline & & & & & 2295 & 2297 & 2210 & Th & TCU & \\
\hline & & & & & 4161 & 4173 & 3985 & $\mathrm{Pz}$ & $\mathrm{CA}$ & \\
\hline \multirow[t]{7}{*}{ TWC } & 790082 & 692061 & 3921 & 1701 & 503 & 1548 & 215 & Tpt & WTA & $?$ \\
\hline & & & & & & & 510 & Th & TCU & \\
\hline & & & & & & & 560 & Twlb & TCU & \\
\hline & & & & & & & 659 & Tc & TCU & \\
\hline & & & & & & & 659 & Tn4 & TCU & \\
\hline & & & & & & & 1210 & Ton1 & TCU & \\
\hline & & & & & & & 1355 & $\mathrm{Pz}$ & $\mathrm{CA}$ & \\
\hline \multirow[t]{4}{*}{ TWB } & 812044 & 690713 & 3929 & 1675 & 395 & 1450 & 0 & QTa & AA & 2.155 \\
\hline & & & & & & & 950 & Tmr & WTA & \\
\hline & & & & & & & 1297 & Tmrl/Th & VTATTCU & \\
\hline & & & & & & & 1411 & Tpt & WTA & \\
\hline ER-6-1 & 814004 & 696780 & 3933 & 3206 & 2129 & 3206 & 1770 & $\mathrm{Pz}$ & $\mathrm{CA}$ & 3.3 \\
\hline ER-6-2 & 805317 & 672494 & 4231 & 3430 & 2006 & 3430 & 101 & $\mathrm{Pz}$ & $\mathrm{CA}$ & 3.4 \\
\hline U7a & 858614 & 684999 & 4255 & 2699 & 2600 & 2605 & 1610 & Tn4 & $\mathrm{TCU}$ & 3.5 \\
\hline
\end{tabular}


APPENDIX A Core and Borehole Information for Conventional Core Holes in Yucca Flat

\begin{tabular}{|c|c|c|c|c|c|c|c|c|c|c|}
\hline \multirow[t]{2}{*}{ Core Hole } & \multicolumn{2}{|c|}{$\begin{array}{l}\text { Core Hole Location (Central } \\
\text { Nevada State Planar } \\
\text { Coordinates, NAD 27) }\end{array}$} & \multirow[t]{2}{*}{$\begin{array}{c}\text { Surface } \\
\text { Elevation } \\
\text { (above mean } \\
\text { sea level) }\end{array}$} & \multirow[t]{2}{*}{$\begin{array}{l}\text { Total } \\
\text { Depth }\end{array}$} & \multicolumn{2}{|c|}{$\begin{array}{c}\text { Depth of Cored } \\
\text { Interval }\end{array}$} & \multirow[t]{2}{*}{$\begin{array}{l}\text { Depth to Top of } \\
\text { Stratigraphic } \\
\text { Unit }\end{array}$} & \multirow[t]{2}{*}{$\begin{array}{c}\text { Stratigraphic } \\
\text { Unit }^{*}\end{array}$} & \multirow[t]{2}{*}{$\begin{array}{c}\text { Hydrogeologic } \\
\text { Unit }^{* *}\end{array}$} & \multirow[t]{2}{*}{$\begin{array}{l}\text { Core } \\
\text { Diameter } \\
\text { (inches) }\end{array}$} \\
\hline & Northing & Easting & & & Top & Bottom & & & & \\
\hline \multirow[t]{7}{*}{ U7a\#1 } & 858619 & 684970 & 4255 & 1350 & 800 & 806 & 770 & Tmr & WTA & 3.5 \\
\hline & & & & & 1100 & 1108 & 1010 & $\mathrm{Tmrl} / \mathrm{Th}$ & VTA & \\
\hline & & & & & 1150 & 1158 & 1010 & Tmrl/Th & TCU & \\
\hline & & & & & 1200 & 1208 & 1010 & $\mathrm{Tmrl} / \mathrm{Th}$ & TCU & \\
\hline & & & & & 1250 & 1258 & 1010 & Tmrl/Th & TCU & \\
\hline & & & & & 1300 & 1303 & 1010 & $\mathrm{Tmrl} / \mathrm{Th}$ & TCU & \\
\hline & & & & & 1342 & 1348 & 1010 & Tmrl/Th & TCU & \\
\hline \multirow[t]{4}{*}{ U7h\#1 } & 848043 & 685457 & 4118 & 1250 & 660 & 912 & 0 & QTa & $A A$ & 3 \\
\hline & & & & & & & 758 & Tma & WTA & \\
\hline & & & & & & & 790 & Tmr & WTA & \\
\hline & & & & & & & 890 & $\mathrm{Tmrl} / \mathrm{Th}$ & VTA & \\
\hline $\mathrm{U} 7 \mathrm{z}$ & 849449 & 683799 & 4108 & 1906 & 1903 & 1906 & $\frac{050}{1510}$ & $\mathrm{Tmrl} / \mathrm{Th}$ & TCU & $?$ \\
\hline U7ab & 848501 & 694000 & 4251 & 1703 & 1700 & 1703 & 1630 & Toy & TCU & $?$ \\
\hline U7ac & 846900 & 685200 & 4102 & 2213 & 2210 & 2213 & 2205 & Toy & TCU & $?$ \\
\hline U7ad & 857308 & 686615 & 4285 & 1965 & 1850 & 1853 & 1820 & Ton2 & TCU & $?$ \\
\hline \multirow{2}{*}{ U7ae } & 851150 & 692450 & 4266 & 2853 & 2050 & 2053 & 2020 & Tor & TCU & $?$ \\
\hline & & & & & 2843 & 2853 & 2690 & $\mathrm{Pz}$ & $\mathrm{CA}$ & \\
\hline U7 af & 853100 & 686500 & 4207 & 1988 & 1988 & 1990 & 1855 & Toy & $\mathrm{TCU}$ & $?$ \\
\hline U7ah & 854100 & $\frac{000000}{683902}$ & $\frac{4201}{4180}$ & $\frac{1500}{3210}$ & $\frac{1500}{3201}$ & 3210 & 2830 & $\frac{10 y}{P z}$ & CA & 3.5 \\
\hline U7ai & 844801 & 685699 & 4084 & 2180 & 2180 & 2182 & 1660 & Tn4E & TCU & $?$ \\
\hline U7am & 854100 & 686301 & 4219 & 2050 & 2050 & 2055 & 2020 & Toy & TCU & $?$ \\
\hline U7an & 847000 & 681700 & 4100 & 3161 & 3151 & 3162 & 2915 & Tlt & TCU & $?$ \\
\hline U7ap & 853900 & 681350 & 4148 & 2050 & 2050 & 2053 & 1910 & Toy & TCU & $?$ \\
\hline \multirow{2}{*}{ U7aq } & 845800 & 679901 & 4094 & 3620 & 3500 & 3510 & 3440 & Tit & TCU & 3.5 \\
\hline & & & & & 3610 & 3620 & 3560 & $\mathrm{Pz}$ & CA & \\
\hline U7at & 858800 & 685958 & 4384 & 1510 & 1510 & 1512 & 1401 & $\mathrm{Pz}$ & CA & $?$ \\
\hline \multirow{2}{*}{ UE7a } & 856000 & 681400 & 4163 & 292 & 282 & 292 & 241 & Tma & WTA & 2.155 \\
\hline & & & & & & & 283 & Tmr & WTA & \\
\hline UE7b & 853698 & 681900 & 4153 & 262 & 220 & 262 & 220 & Tmr & VTA & $?$ \\
\hline UE $7 \mathrm{c}$ & 851500 & 681200 & 4131 & 343 & 333 & 343 & 310 & Tma & $?$ & 2.155 \\
\hline UE7d & 851500 & 682400 & 4138 & 298 & 290 & 298 & 150 & Tmr & WTA & 2.155 \\
\hline UE7e & 849400 & 681300 & 4118 & 482 & 472 & 482 & 472 & Tmr & WTA & 2.155 \\
\hline \multirow{18}{*}{ UE7f } & 852510 & 680180 & $\frac{4124}{4124}$ & $\frac{402}{2824}$ & $\frac{412}{770}$ & $\frac{402}{2498}$ & 750 & $\mathrm{Tmr}$ & WTA & 2.5 \\
\hline & & & & & & & 1224 & $\mathrm{Tmrl} / \mathrm{Th}$ & TCU & \\
\hline & & & & & & & 1465 & Twlb & TCU & \\
\hline & & & & & & & $\frac{1460}{1515}$ & Tc & TCU & \\
\hline & & & & & & & 1674 & Tbgb & TCU & \\
\hline & & & & & & & 1074 & Tn4 & TCU & \\
\hline & & & & & & & 1894 & Tn4E & TCU & \\
\hline & & & & & & & 1999 & Tn3 & TCU & \\
\hline & & & & & & & 2047 & Tn3bc & TCU & \\
\hline & & & & & & & 2230 & Tub & TCU & \\
\hline & & & & & & & 2239 & Ton2 & TCU & \\
\hline & & & & & & & 2399 & Toy & TCU & \\
\hline & & & & & & & 2415 & Ton1 & TCU & \\
\hline & & & & & 2498 & 2824 & 2415 & Ton1 & TCU & 2.155 \\
\hline & & & & & & & 2560 & Tot & TCU & \\
\hline & & & & & & & 2573 & $\frac{T}{T V}$ & TCU & \\
\hline & & & & & & & 2796 & Tlt & TCU & \\
\hline & & & & & & & 2804 & $\mathrm{Pz}$ & CA & \\
\hline
\end{tabular}


APPENDIX A

Core and Borehole Information for Conventional Core Holes in Yucca Flat (unless otherwise noted all values are in feet)

\begin{tabular}{|c|c|c|c|c|c|c|c|c|c|c|}
\hline \multirow[t]{2}{*}{ Core Hole } & \multicolumn{2}{|c|}{$\begin{array}{l}\text { Core Hole Location (Central } \\
\text { Nevada State Planar } \\
\text { Coordinates, NAD 27) }\end{array}$} & \multirow[t]{2}{*}{$\begin{array}{l}\text { Surface } \\
\text { Elevation } \\
\text { (above mean } \\
\text { sea level) }\end{array}$} & \multirow[t]{2}{*}{$\begin{array}{l}\text { Total } \\
\text { Depth }\end{array}$} & \multicolumn{2}{|c|}{$\begin{array}{l}\text { Depth of Cored } \\
\text { Interval }\end{array}$} & \multirow[t]{2}{*}{\begin{tabular}{|} 
Depth to Top of \\
Stratigraphic \\
Unit
\end{tabular}} & \multirow[t]{2}{*}{$\begin{array}{c}\text { Stratigraphic } \\
\text { Unit* }\end{array}$} & \multirow[t]{2}{*}{$\begin{array}{c}\text { Hydrogeologic } \\
\text { Unit }^{* \star}\end{array}$} & \multirow[t]{2}{*}{$\begin{array}{l}\text { Core } \\
\text { Diameter } \\
\text { (inches) }\end{array}$} \\
\hline & Northing & Easting & & & Top & Bottom & & & & \\
\hline UE7aa & 845149 & 696449 & 4259 & 2154 & 1575 & 1580 & 1465 & $\mathrm{Pz}$ & $\mathrm{CA}$ & 3.5 \\
\hline \multirow{19}{*}{ UE7ax } & 858084 & 691025 & 4390 & 1359 & 253 & 843 & 0 & QTa & AA & 2.5 \\
\hline & 80000 & J TULU & 4000 & 1000 & 20 & & 264 & $\mathrm{Tmrl} / \mathrm{Th}$ & VTA & \\
\hline & & & & & & & 380 & Twlb & VTA & \\
\hline & & & & & & & 445 & Tc & VTA & \\
\hline & & & & & & & 590 & Tbgb & TCU & \\
\hline & & & & & & & 654 & $\mathrm{Tn} 4$ & TCU & \\
\hline & & & & & & & 788 & Tn4E & TCU & \\
\hline & & & & & 843 & 1169 & 788 & Tn4E & TCU & $2.5,2.155$ \\
\hline & & & & & & & 905 & Tn3 & TCU & \\
\hline & & & & & & & 968 & Tn3bc & TCU & \\
\hline & & & & & & & 1053 & Tub & TCU & \\
\hline & & & & & & & 1067 & Ton2 & TCU & \\
\hline & & & & & & & 1161 & Toy & TCU & \\
\hline & & & & & 1169 & 1359 & 1161 & Toy & TCU & 2.155 \\
\hline & & & & & & & 1239 & Ton1 & TCU & \\
\hline & & & & & & & 1287 & Tot & TCU & \\
\hline & & & & & & & 1335 & Tv & TCU & \\
\hline & & & & & & & 1339 & Tit & TCU & \\
\hline & & & & & & & 1343 & $\mathrm{Pz}$ & CA & \\
\hline \multirow[t]{16}{*}{ UE7az } & 850000 & 690800 & 4218 & 2441 & 1021 & 2363 & 880 & $\mathrm{Tmr}$ & VTA & 2.5 \\
\hline & & & & & & & 1088 & $\mathrm{Tmrl} / \mathrm{Th}$ & TCU & \\
\hline & & & & & & & 1236 & Twlb & TCU & \\
\hline & & & & & & & 1306 & Tc & TCU & \\
\hline & & & & & & & 1474 & Tbgb & TCU & \\
\hline & & & & & & & 1475 & $\mathrm{Tn} 4$ & TCU & \\
\hline & & & & & & & 1532 & Tn4E & TCU & \\
\hline & & & & & & & 1726 & Tn3 & TCU & \\
\hline & & & & & & & 1750 & Tn3bc & TCU & \\
\hline & & & & & & & 1825 & Ton2 & TCU & \\
\hline & & & & & & & 1868 & Tor & TCU & \\
\hline & & & & & & & 2007 & Tot & TCU & \\
\hline & & & & & & & 2135 & Tv & TCU & \\
\hline & & & & & & & 2240 & TIt & TCU & \\
\hline & & & & & 2364 & 2441 & 2240 & Tlt & TCU & 2.155 \\
\hline & & & & & & & 2432 & $\mathrm{Pz}$ & CA & \\
\hline \multirow{16}{*}{ UE7ba } & 851264 & 681350 & 4130 & 2428 & 360 & 2428 & 314 & Tma & WTA & 2.5 \\
\hline & & & & & & & 440 & Tmr & WTA & \\
\hline & & & & & & & 912 & $\mathrm{Tmrl} / \mathrm{Th}$ & TCU & \\
\hline & & & & & & & 1237 & Twlb & TCU & \\
\hline & & & & & & & 1290 & Tc & TCU & \\
\hline & & & & & & & 1525 & Tbgb & TCU & \\
\hline & & & & & & & 1526 & $\operatorname{Tn} 4$ & TCU & \\
\hline & & & & & & & 1629 & Tn4E & TCU & \\
\hline & & & & & & & 1763 & $\operatorname{Tn} 3$ & TCU & \\
\hline & & & & & & & 1837 & $\operatorname{Tn} 3 b c$ & TCU & \\
\hline & & & & & & & 1967 & Tub & TCU & \\
\hline & & & & & & & 1975 & Ton2 & TCU & \\
\hline & & & & & & & 2096 & Toy & TCU & \\
\hline & & & & & & & 2201 & Ton1 & TCU & \\
\hline & & & & & & & 2382 & Tlt & TCU & \\
\hline & & & & & & & 2396 & $\mathrm{Pz}$ & CA & \\
\hline
\end{tabular}


APPENDIX A

Core and Borehole Information for Conventional Core Holes in Yucca Flat (unless otherwise noted all values are in feet)

\begin{tabular}{|c|c|c|c|c|c|c|c|c|c|c|}
\hline \multirow[t]{2}{*}{ Core Hole } & \multicolumn{2}{|c|}{$\begin{array}{l}\text { Core Hole Location (Central } \\
\text { Nevada State Planar } \\
\text { Coordinates, NAD 27) }\end{array}$} & \multirow[t]{2}{*}{$\begin{array}{c}\text { Surface } \\
\text { Elevation } \\
\text { (above mean } \\
\text { sea level) }\end{array}$} & \multirow[t]{2}{*}{$\begin{array}{l}\text { Total } \\
\text { Depth }\end{array}$} & \multicolumn{2}{|c|}{$\begin{array}{l}\text { Depth of Cored } \\
\text { Interval }\end{array}$} & \multirow[t]{2}{*}{$\begin{array}{l}\text { Depth to Top of } \\
\text { Stratigraphic } \\
\text { Unit }\end{array}$} & \multirow[t]{2}{*}{$\begin{array}{c}\text { Stratigraphic } \\
\text { Unit* }^{*}\end{array}$} & \multirow[t]{2}{*}{$\begin{array}{c}\text { Hydrogeologic } \\
\text { Unit }^{* *}\end{array}$} & \multirow[t]{2}{*}{$\begin{array}{l}\text { Core } \\
\text { Diameter } \\
\text { (inches) }\end{array}$} \\
\hline & Northing & Easting & & & Top & Bottom & & & & \\
\hline \multirow[t]{16}{*}{ UE7bc } & 848000 & 693154 & 4225 & 2707 & 740 & 2707 & 646 & $\mathrm{Tmrl} / \mathrm{Th}$ & TCU & 2.5 \\
\hline & & & & & & & 830 & Twlb & TCU & \\
\hline & & & & & & & 900 & Tc & TCU & \\
\hline & & & & & & & 1043 & Tbgb & TCU & \\
\hline & & & & & & & 1058 & Tn4 & TCU & \\
\hline & & & & & & & 1200 & Tn4E & TCU & \\
\hline & & & & & & & 1240 & Tn3 & TCU & \\
\hline & & & & & & & 1397 & $\operatorname{Tn} 3 b c$ & TCU & \\
\hline & & & & & & & 1689 & Toy & TCU & \\
\hline & & & & & & & 1877 & Ton1 & TCU & \\
\hline & & & & & & & 1958 & Tor & TCU & \\
\hline & & & & & & & 2340 & TV & TCU & \\
\hline & & & & & & & 2467 & Tot & TCU & \\
\hline & & & & & & & 2567 & TV & TCU & \\
\hline & & & & & & & 2592 & Titt & TCU & \\
\hline & & & & & & & 2699 & $\mathrm{Pz}$ & $\mathrm{CA}$ & \\
\hline UE7be & 856500 & 685521 & 4241 & 2604 & 2602 & 2604 & 2570 & $\mathrm{Pz}$ & $\mathrm{CA}$ & $?$ \\
\hline \multirow[t]{11}{*}{ UE7ns } & 855600 & 693700 & 4367 & 2205 & 1666 & 1673 & 1640 & $\mathrm{Pz}$ & $\mathrm{CA}$ & $?$ \\
\hline & & & & & 1724 & 1730 & 1640 & $\mathrm{Pz}$ & CA & \\
\hline & & & & & 1798 & 1803 & 1640 & $\mathrm{Pz}$ & CA & \\
\hline & & & & & 1848 & 1854 & 1640 & $\mathrm{Pz}$ & CA & \\
\hline & & & & & 1898 & 1908 & 1640 & $\mathrm{Pz}$ & $\mathrm{CA}$ & \\
\hline & & & & & 1948 & 1954 & 1640 & $\mathrm{Pz}$ & $\mathrm{CA}$ & \\
\hline & & & & & 1998 & 2008 & 1640 & $\mathrm{Pz}$ & CA & \\
\hline & & & & & 2048 & 2058 & 1640 & $\mathrm{Pz}$ & CA & \\
\hline & & & & & 2110 & 2120 & 1640 & $\mathrm{Pz}$ & CA & \\
\hline & & & & & 2148 & 2155 & 1640 & $\mathrm{Pz}$ & CA & \\
\hline & & & & & 2190 & 2200 & 1640 & $\mathrm{Pz}$ & $\mathrm{CA}$ & \\
\hline U8a\#1 & 884497 & 665748 & 4613 & 1238 & 1230 & 1238 & 1175 & $\mathrm{Pz}$ & $\mathrm{CCU}$ & $?$ \\
\hline U8a\#3 & 884288 & 665728 & 4610 & 1322 & 1314 & 1322 & 1250 & $\mathrm{Pz}$ & $?$ & 4 \\
\hline \multirow[t]{2}{*}{ U8a\#4 } & 884358 & 665734 & 4614 & 1925 & 1128 & 1406 & 1050 & $\mathrm{Tn}$ & $?$ & 3.5 \\
\hline & & & & & & & 1214 & $\mathrm{Pz}$ & $\mathrm{CCU}$ & \\
\hline \multirow[t]{5}{*}{ U8a\#5 } & 884010 & 665698 & 4604 & 1915 & 607 & 1652 & 591 & Tmr & VTA & 3.5 \\
\hline & & & & & & & 830 & $\mathrm{Tp}$ & VTA & \\
\hline & & & & & & & 899 & Tbgb & VTA & \\
\hline & & & & & & & 971 & $\mathrm{Tn}$ & VTA & \\
\hline & & & & & & & 1270 & $\mathrm{Pz}$ & $\mathrm{CCU}$ & \\
\hline \multirow[t]{2}{*}{ U8a\#9 } & 882816 & 665574 & 4575 & 1860 & 1330 & 1432 & 1181 & TV & $?$ & 3.5 \\
\hline & & & & & & & 1381 & $\mathrm{Pz}$ & $?$ & \\
\hline \multirow[t]{7}{*}{ U8a\#10 } & 882419 & 665534 & 4569 & 1918 & 872 & 1918 & 0 & QTa & $\dot{\mathrm{AA}}$ & 3.5 \\
\hline & & & & & & & 906 & Tma & $?$ & \\
\hline & & & & & & & 991 & Tmr & $?$ & \\
\hline & & & & & & & 1138 & TV & $?$ & \\
\hline & & & & & & & 1224 & Tbgb & $?$ & \\
\hline & & & & & & & 1280 & $\mathrm{Tn}$ & $?$ & \\
\hline & & & & & & & 1450 & $\mathrm{Pz}$ & $?$ & \\
\hline
\end{tabular}


APPENDIX A

Core and Borehole Information for Conventional Core Holes in Yucca Flat (unless otherwise noted all values are in feet)

\begin{tabular}{|c|c|c|c|c|c|c|c|c|c|c|}
\hline \multirow[t]{2}{*}{ Core Hole } & \multicolumn{2}{|c|}{$\begin{array}{l}\text { Core Hole Location (Central } \\
\text { Nevada State Planar } \\
\text { Coordinates, NAD 27) }\end{array}$} & \multirow[t]{2}{*}{$\begin{array}{c}\text { Surface } \\
\text { Elevation } \\
\text { (above mean } \\
\text { sea level) } \\
\end{array}$} & \multirow[t]{2}{*}{$\begin{array}{l}\text { Total } \\
\text { Depth }\end{array}$} & \multicolumn{2}{|c|}{$\begin{array}{l}\text { Depth of Cored } \\
\text { Interval }\end{array}$} & \multirow[t]{2}{*}{$\begin{array}{c}\text { Depth to Top of } \\
\text { Stratigraphic } \\
\text { Unit }\end{array}$} & \multirow[t]{2}{*}{$\begin{array}{c}\text { Stratigraphic } \\
\text { Unit* }^{*}\end{array}$} & \multirow[t]{2}{*}{$\underset{\text { Unit }^{* *}}{\text { Hydrogeologic }}$} & \multirow[t]{2}{*}{$\begin{array}{l}\text { Core } \\
\text { Diameter } \\
\text { (inches) }\end{array}$} \\
\hline & Northing & Easting & & & Top & Bottom & & & & \\
\hline UE8d & 882280 & 671280 & 4438 & 1246 & 1239 & 1246 & 1175 & $\mathrm{Pz}$ & $\overline{C A}$ & 3.5 \\
\hline UE8e & 881600 & 668700 & 4489 & 2470 & 1800 & 1810 & 1710 & Tv & TCU & 3.5 \\
\hline \multirow[t]{4}{*}{ UE8 $\mathrm{f}$} & 882386 & 666019 & 4560 & 2248 & 1109 & 1118 & 1099 & Tma & VTA & $?$ \\
\hline & & & & & 1155 & 1165 & 1099 & Tma & VTA & \\
\hline & & & & & & & 1158 & Tbgb & VTA & \\
\hline & & & & & 2235 & 2248 & 2139 & $\mathrm{Pz}$ & $\mathrm{CCU}$ & \\
\hline UE8h & 882756 & 664746 & 4594 & 1610 & 1298 & 1305 & 1230 & $\mathrm{Pz}$ & $\mathrm{CA}$ & 3.5 \\
\hline \multirow[t]{2}{*}{ UE8i } & 882139 & 665388 & 4566 & 1200 & 300 & 306 & 0 & QTa & $\mathrm{AA}$ & $?$ \\
\hline & & & & & 808 & 809 & 0 & $\mathrm{QTa}$ & AA & \\
\hline \multirow[t]{2}{*}{ U9d\#1 } & 864046 & 680127 & & 1010 & 840 & 999 & 0 & QTa & $\mathrm{AA}$ & 3.5 \\
\hline & & & & & & & 850 & Tmr & WTA & \\
\hline U9i\#1 & 864306 & 685898 & 4230 & 758 & 600 & 610 & 351 & TV & TCU & 3.5 \\
\hline U9itz2 & $?$ & $?$ & $?$ & $?$ & 850 & 860 & & $?$ & $?$ & 3.5 \\
\hline U9k & 862910 & 685180 & 4261 & 782 & 775 & 785 & 650 & Tv & $?$ & $?$ \\
\hline \multirow{2}{*}{ U9n } & 865860 & 681270 & 4200 & 595 & 450 & 460 & 0 & QTa & AA & $?$ \\
\hline & & & & & 570 & 574 & 0 & QTa & AA & \\
\hline U9q & 864231 & 679548 & 4198 & 715 & 690 & 698 & 0 & QTa & AA & 3.5 \\
\hline U9r & 866002 & 680269 & 4204 & 595 & 545 & 555 & 0 & $\mathrm{QTa}$ & AA & 3.5 \\
\hline U9u & 867001 & 681301 & 4204 & 595 & 570 & 580 & 0 & QTa & AA & 3.5 \\
\hline U9v & 862300 & 680550 & 4177 & 875 & 850 & 860 & 0 & QTa & AA & 3.5 \\
\hline U9w & 863480 & 683790 & 4225 & 610 & 590 & 600 & 0 & QTa & AA & 3.5 \\
\hline \multirow[t]{2}{*}{ U9x } & 862060 & 684820 & 4258 & 865 & 760 & 765 & 551 & Tmr & WTA & 3.5 \\
\hline & & & & & 850 & 860 & 551 & Tmr & WTA & \\
\hline U9y & 866761 & 677878 & 4239 & 735 & 710 & 720 & 0 & QTa & AA & 3.5 \\
\hline U9z & 862760 & 682860 & 4208 & 765 & 750 & 760 & 0 & QTa & $\mathrm{AA}$ & 3.5 \\
\hline U9aa & 866180 & 679770 & 4209 & 760 & 740 & 750 & 0 & $\mathrm{QTa}$ & AA & $?$ \\
\hline U9ab & 863360 & 681040 & 4187 & 765 & 740 & 748 & 0 & QTa & AA & 3.5 \\
\hline U9ac & 865369 & 681300 & 4197 & 450 & 430 & 438 & 0 & QTa & AA & 3.5 \\
\hline \multirow[t]{2}{*}{ U9ad } & 870300 & 679650 & 4234 & 1813 & 1615 & 1625 & 1460 & Tmr & VTA & \\
\hline & & & & & 1805 & 1813 & 1460 & Tmr & VTA & 3.5 \\
\hline U9ae & 859999 & 683000 & 4213 & 1323 & 943 & 949 & 899 & Tmr & WTA & 3.5 \\
\hline U9ak & 865071 & 684039 & 4267 & 860 & 823 & 831 & 732 & Tv & $?$ & $?$ \\
\hline U9ao & 871350 & 679999 & 4231 & 1655 & 1621 & 1629 & $\frac{7}{1549}$ & Tv & VTA & 3.5 \\
\hline U9ay & 865600 & 683771 & 4221 & 909 & 685 & 693 & 551 & Tmr & WTA & $?$ \\
\hline U9bb\#1 & 867645 & 684910 & 4254 & 800 & 792 & 800 & 390 & Tmr & WTA & 3.5 \\
\hline \multirow[t]{3}{*}{ U9bd\#1 } & 860969 & 686944 & 4317 & 650 & 556 & 558 & 499 & Tmr & VTA & $?$ \\
\hline & & & & & 600 & 608 & 499 & Tmr & VTA & \\
\hline & & & & & & & 607 & TV & VTA & \\
\hline \multirow[t]{2}{*}{ U9be\#1 } & 860028 & 686022 & 4287 & 725 & 572 & 725 & 479 & Tmr & VTA & 3.5 \\
\hline & & & & & & & 722 & TV & VTA & \\
\hline \multirow[t]{2}{*}{ U9bh\#1 } & 862940 & 687167 & 4310 & 810 & 665 & 673 & 217 & Tmr & WTA & $?$ \\
\hline & & & & & 715 & 808 & 217 & Tmr & WTA & \\
\hline U9bi\#1 & 860600 & 686820 & 4314 & 800 & 690 & 748 & 522 & Tmr & WTA & 3.5 \\
\hline U9bn\#1 & 862762 & 686315 & 4292 & 979 & 820 & 916 & 509 & Tv & VTA & $?$ \\
\hline \multirow{2}{*}{ U9bp\#1 } & 861451 & 684980 & 4264 & 800 & 636 & 800 & 0 & QTa & AA & 3.5 \\
\hline & & & & & & & 679 & Tmr & WTA & \\
\hline
\end{tabular}


APPENDIX A

Core and Borehole Information for Conventional Core Holes in Yucca Flat (unless otherwise noted all values are in feet)

\begin{tabular}{|c|c|c|c|c|c|c|c|c|c|c|}
\hline \multirow[t]{2}{*}{ Core Hole } & \multicolumn{2}{|c|}{$\begin{array}{l}\text { Core Hole Location (Central } \\
\text { Nevada State Planar } \\
\text { Coordinates, NAD 27) }\end{array}$} & \multirow[t]{2}{*}{$\begin{array}{c}\text { Surface } \\
\text { Elevation } \\
\text { (above mean } \\
\text { sea level) } \\
\end{array}$} & \multirow[t]{2}{*}{$\begin{array}{l}\text { Total } \\
\text { Depth }\end{array}$} & \multicolumn{2}{|c|}{$\begin{array}{l}\text { Depth of Cored } \\
\text { Interval }\end{array}$} & \multirow[t]{2}{*}{$\begin{array}{c}\text { Depth to Top of } \\
\text { Stratigraphic } \\
\text { Unit }\end{array}$} & \multirow[t]{2}{*}{$\begin{array}{c}\text { Stratigraphic } \\
\text { Unit* }\end{array}$} & \multirow[t]{2}{*}{$\begin{array}{c}\text { Hydrogeologic } \\
\text { Unit }^{* \star}\end{array}$} & \multirow[t]{2}{*}{$\begin{array}{l}\text { Core } \\
\text { Diameter } \\
\text { (inches) }\end{array}$} \\
\hline & Northing & Easting & & & Top & Bottom & & & & \\
\hline \multirow[t]{8}{*}{ U9br\#1 } & 861915 & 686335 & 4298 & 1000 & 450 & 458 & 374 & Tmr & VTA & 3.5 \\
\hline & & & & & 650 & 658 & 564 & TV & VTA & \\
\hline & & & & & 710 & 718 & 564 & TV & VTA & \\
\hline & & & & & 800 & 808 & 564 & Tv & VTA & \\
\hline & & & & & 850 & 858 & 564 & TV & VTA & \\
\hline & & & & & 900 & 908 & 564 & TV & VTA & \\
\hline & & & & & 941 & 947 & 564 & $\mathrm{TV}$ & VTA & \\
\hline & & & & & 992 & 1000 & 951 & Tbgb & VTA & \\
\hline \multirow[t]{9}{*}{ U9ca\#1 } & 872700 & 679098 & 4244 & 3210 & 1400 & 1408 & 0 & QTa & AA & 3.5 \\
\hline & & & & & & & 1401 & TV & VTA & \\
\hline & & & & & 1700 & 1708 & 1401 & TV & VTA & \\
\hline & & & & & 1950 & 1958 & 1939 & Tbgb & TCU & \\
\hline & & & & & 2050 & 2058 & 1939 & Tbgb & TCU & \\
\hline & & & & & 2150 & 2158 & 1939 & Tbgb & TCU & \\
\hline & & & & & 2236 & 2249 & 1939 & Tbgb & TCU & \\
\hline & & & & & 3077 & 3085 & 1939 & Tbgb & TCU & \\
\hline & & & & & & & 3081 & $\mathrm{Pz}$ & CA & \\
\hline \multirow[t]{6}{*}{ U9cb\#4 } & 873298 & 681856 & 4245 & 1858 & 1471 & 1479 & 1329 & $\mathrm{Tn}$ & $\mathrm{CA}$ & $?$ \\
\hline & & & & & 1569 & 1577 & 1329 & Tn & $?$ & \\
\hline & & & & & 1676 & 1684 & 1329 & $\mathrm{Tn}$ & $?$ & \\
\hline & & & & & 1721 & 1729 & 1329 & $\mathrm{Tn}$ & $?$ & \\
\hline & & & & & 1771 & 1779 & 1329 & Tn & $?$ & \\
\hline & & & & & 1850 & 1858 & 1329 & $\mathrm{Tn}$ & $?$ & \\
\hline U9ce\#1 & 871860 & 678982 & 4242 & 1420 & 1196 & 1204 & 0 & QTa & $\mathrm{AA}$ & 3.5 \\
\hline \multirow[t]{3}{*}{ U9ci\#1 } & 863795 & 684966 & 4249 & 1239 & 463 & 493 & 0 & QTa & AA & $?$ \\
\hline & & & & & 496 & 515 & 0 & QTa & AA & \\
\hline & & & & & & & 499 & Tmr & VTA & \\
\hline U9itsUEs 25 & 869990 & 682296 & 4222 & 2028 & 2025 & 2028 & 1959 & $\mathrm{Pz}$ & CA & 3.5 \\
\hline U9itsUEu22 & 868840 & 683200 & 4223 & 1817 & 940 & 1024 & 853 & Tc & $?$ & $?$ \\
\hline UEu 29\#1 & 871618 & 683624 & 4248 & 1248 & 1228 & 1248 & 1138 & $\mathrm{Pz}$ & CA & 3.5 \\
\hline UEu 29\#2 & 871505 & 683105 & 4242 & 1572 & 1542 & 1546 & 1421 & $\mathrm{Pz}$ & $\mathrm{CA}$ & 3.5 \\
\hline FT1 & $?$ & $?$ & $?$ & $?$ & 0 & 100 & $?$ & $?$ & $?$ & 2.155 \\
\hline FT1\#1 & $?$ & $?$ & $?$ & $?$ & 0 & 17 & $?$ & $?$ & $?$ & 2.155 \\
\hline FT1\#2 & $?$ & $?$ & $?$ & $?$ & 0 & 10 & $?$ & $?$ & $?$ & 2.155 \\
\hline FT1\#3 & $?$ & $?$ & $?$ & $?$ & 0 & 10 & $?$ & $?$ & $?$ & 2.155 \\
\hline A3\#1 & $?$ & $?$ & $?$ & $?$ & 0 & 50 & $?$ & $?$ & $?$ & 2.155 \\
\hline U10a & 883040 & 677799 & 4293 & 1410 & 1300 & 1410 & 1129 & $\mathrm{Tn}$ & $?$ & 3.5 \\
\hline U10b & 883000 & 674700 & 4375 & 1501 & 1300 & 1339 & 591 & $\mathrm{Pz}$ & $\mathrm{CA}$ & 3.5 \\
\hline U10b\#3 & 883000 & 674725 & 4375 & 1400 & 667 & 1339 & 551 & $\mathrm{Pz}$ & $\mathrm{CA}$ & 3.5 \\
\hline U10b\#4 & 883700 & 674700 & 4379 & 1400 & 706 & 1348 & 702 & $\mathrm{Pz}$ & $C A$ & 3.5 \\
\hline U10b\#5 & 884399 & 674700 & 4388 & 1400 & 733 & 1358 & 678 & $\mathrm{Pz}$ & CA & 3.5 \\
\hline \multirow[t]{3}{*}{ U10c\#1 } & 874028 & 678179 & 4260 & 3058 & 1600 & 3058 & 1549 & Tmr & WTA & 3.5 \\
\hline & & & & & & & 1900 & TV & VTA & \\
\hline & & & & & & & 3051 & $\mathrm{Pz}$ & $\mathrm{CA}$ & \\
\hline & 874500 & 682599 & 4266 & 1635 & 1600 & 1608 & 1240 & $\mathrm{Tn}$ & TCU & 3.5 \\
\hline \multirow{5}{*}{ U10e\#1 } & 874508 & 682581 & 4266 & 1700 & 600 & 608 & 554 & Tmr & WTA & $?$ \\
\hline & & & & & 1230 & 1235 & 1171 & Tbgb & $?$ & \\
\hline & & & & & 1415 & 1420 & 1240 & $\mathrm{Tn}$ & $?$ & \\
\hline & & & & & 1515 & 1523 & 1240 & $\mathrm{Tn}$ & $?$ & \\
\hline & & & & & 1687 & 1695 & 1240 & $\mathrm{Tn}$ & $?$ & \\
\hline U10i & 885894 & 680999 & 4335 & 1745 & 1745 & 1753 & 1640 & $\mathrm{Pz}$ & CA & \\
\hline
\end{tabular}


APPENDIX A

Core and Borehole Information for Conventional Core Holes in Yucca Flat (unless otherwise noted all values are in feet)

\begin{tabular}{|c|c|c|c|c|c|c|c|c|c|c|}
\hline \multirow[t]{2}{*}{ Core Hole } & \multicolumn{2}{|c|}{$\begin{array}{l}\text { Core Hole Location (Central } \\
\text { Nevada State Planar } \\
\text { Coordinates, NAD 27) }\end{array}$} & \multirow[t]{2}{*}{$\begin{array}{c}\text { Surface } \\
\text { Elevation } \\
\text { (above mean } \\
\text { sea level) }\end{array}$} & \multirow[t]{2}{*}{$\begin{array}{l}\text { Total } \\
\text { Depth }\end{array}$} & \multicolumn{2}{|c|}{$\begin{array}{l}\text { Depth of Cored } \\
\text { Interval }\end{array}$} & \multirow[t]{2}{*}{$\begin{array}{c}\text { Depth to Top of } \\
\text { Stratigraphic } \\
\text { Unit }\end{array}$} & \multirow[t]{2}{*}{$\begin{array}{c}\text { Stratigraphic } \\
\text { Unit }^{*}\end{array}$} & \multirow[t]{2}{*}{$\begin{array}{c}\text { Hydrogeologic } \\
\text { Unit }^{* *}\end{array}$} & \multirow[t]{2}{*}{$\begin{array}{c}\text { Core } \\
\text { Diameter } \\
\text { (inches) }\end{array}$} \\
\hline & Northing & Easting & & & Top & Bottom & & & & \\
\hline \multirow[t]{3}{*}{ U10i\#1 } & 885872 & 681020 & 4335 & 1360 & 950 & 1358 & 850 & TV & $?$ & 4 \\
\hline & & & & & & & 974 & Tbgb & $?$ & \\
\hline & & & & & & & 1050 & $\mathrm{TV}$ & $?$ & \\
\hline \multirow[t]{2}{*}{ U10k } & 879520 & 679000 & 4273 & 2391 & 1843 & 1851 & 1729 & $\mathrm{Tn}$ & $\mathrm{TCU}$ & \\
\hline & & & & & 1960 & 1968 & 1729 & $\mathrm{Tn}$ & $\mathrm{TCU}$ & 3.5 \\
\hline \multirow[t]{2}{*}{ U10k\#1 } & 879475 & 679030 & 4272 & 2289 & 2173 & 2192 & 1729 & Tn & TCU & 4 \\
\hline & & & & & 2207 & 2243 & 1729 & $\mathrm{Tn}$ & TCU & \\
\hline \multirow[t]{6}{*}{ U10|\#1 } & 875918 & 681559 & 4264 & 2208 & 1070 & 1078 & 1024 & TV & VTA & 3.5 \\
\hline & & & & & 1200 & 1208 & 1024 & TV & TCU & \\
\hline & & & & & 1470 & 1478 & 1460 & $\mathrm{Tn}$ & TCU & \\
\hline & & & & & 1570 & 1578 & 1460 & Tn & TCU & \\
\hline & & & & & 1770 & 1778 & 1460 & $\mathrm{Tn}$ & TCU & \\
\hline & & & & & 1870 & 1878 & 1460 & $\mathrm{Tn}$ & TCU & \\
\hline U10n\#1 & 883949 & 674700 & 4382 & 1115 & 729 & 783 & 722 & $\mathrm{Pz}$ & $\mathrm{CA}$ & 3.5 \\
\hline \multirow[t]{10}{*}{ UE10j } & 887033 & 670453 & 4574 & 2613 & 370 & 378 & 358 & Tub & TCU & 3.5 \\
\hline & & & & & 668 & 676 & 623 & Tor & TCU & \\
\hline & & & & & 750 & 758 & 748 & Tot & TCU & \\
\hline & & & & & 1035 & 1038 & 1024 & $\mathrm{Pz}$ & CA & \\
\hline & & & & & 1290 & 1295 & 1024 & $\mathrm{Pz}$ & CA & \\
\hline & & & & & 1620 & 1623 & 1024 & $?$ & $\mathrm{CA}$ & \\
\hline & & & & & 1640 & 1644 & 1024 & $\mathrm{Pz}$ & CA & \\
\hline & & & & & 1860 & 1865 & 1024 & $\mathrm{Pz}$ & $\mathrm{CA}$ & \\
\hline & & & & & 2050 & 2058 & 1024 & $\mathrm{Pz}$ & CA & \\
\hline & & & & & 2150 & 2156 & 1024 & $\mathrm{Pz}$ & CA & \\
\hline \multirow[t]{3}{*}{ U10aq\#1 } & 879503 & 684717 & 4343 & 1637 & 900 & 1020 & 814 & Tbgb & VTA & $?$ \\
\hline & & & & & & & 919 & $\mathrm{Tn}$ & TCU & \\
\hline & & & & & 1100 & 1120 & 919 & $\mathrm{Tn}$ & TCU & \\
\hline & 889500 & 683300 & 4401 & 1390 & 1266 & & 1132 & & ccll & \\
\hline
\end{tabular}




\section{EXPLANATION}

\section{* Stratigraphic Unit Symbols}

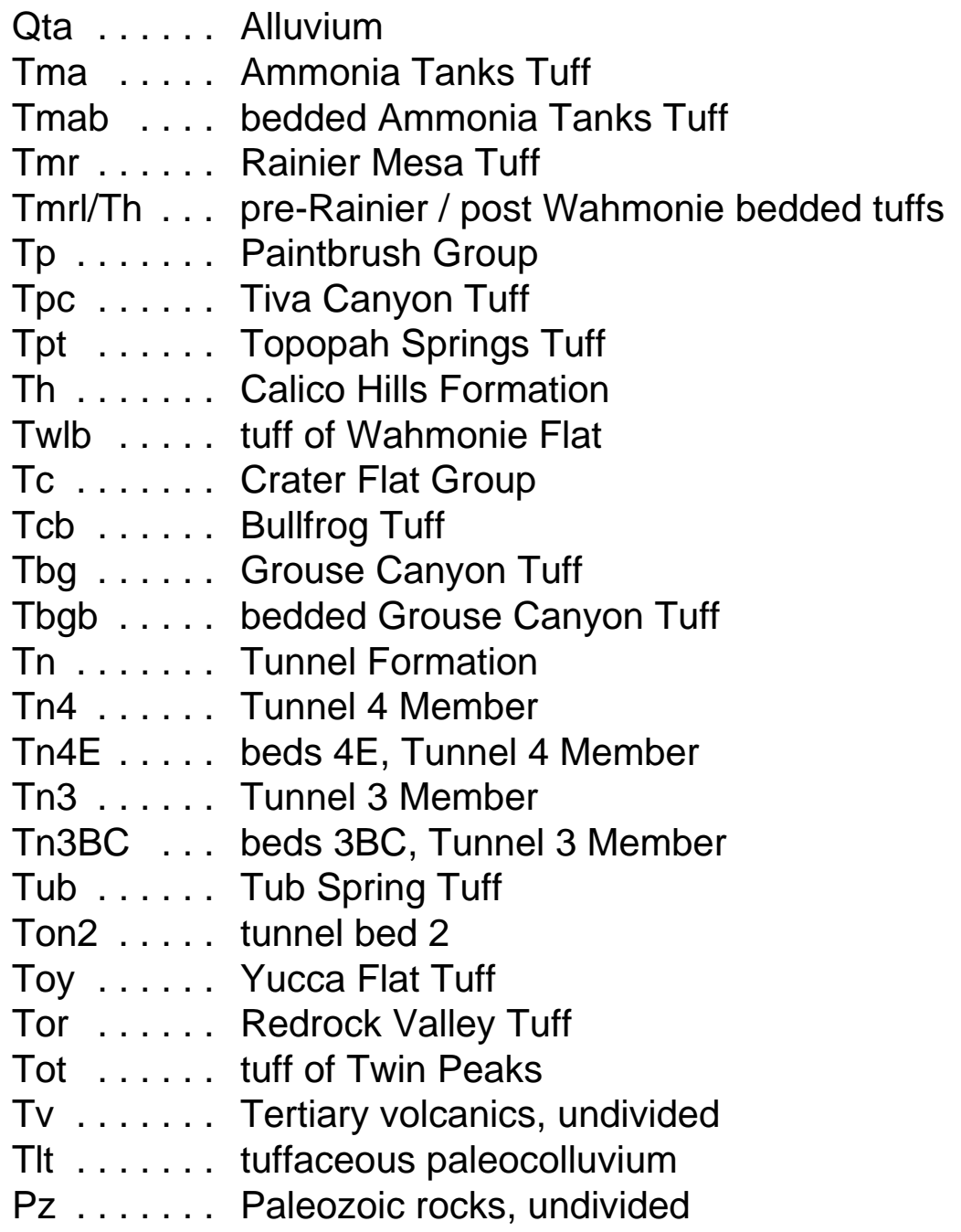

\section{** Hydrogeologic Unit Symbols}
AA ...... alluvial aquifer
VTA ...... vitric-tuff aquifer WTA .... . welded-tuff aquifer TCU ..... tuff confining unit CCU .... . clastic confining unit CA ...... carbonate aquifer 


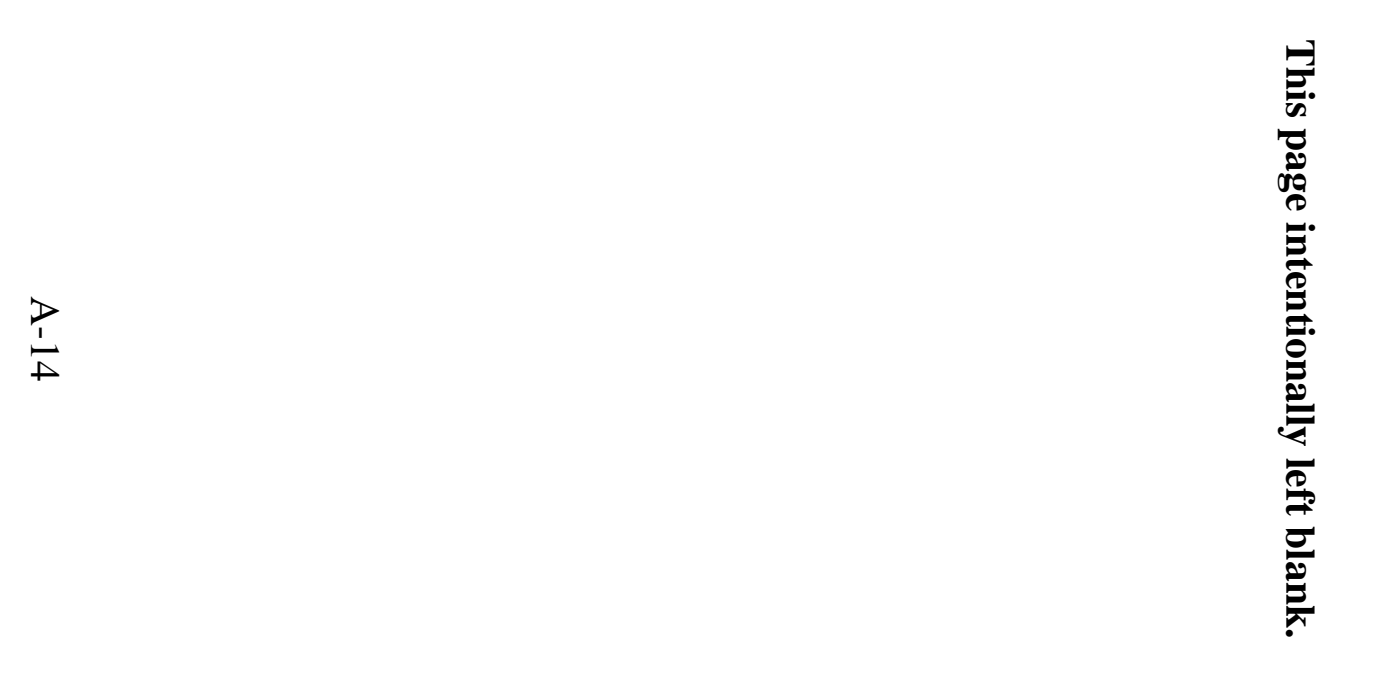




\section{Distribution List}

\section{$\underline{\text { Copies }}$}

W. R. Wilborn

5 (2 paper, 3 CDs)

Environmental Restoration Project

Nevada Site Office

National Nuclear Security Administration

Environmental Restoration Division

P.O. Box 98518, M/S 505

Las Vegas, NV 89193-8518

U.S. Department of Energy

National Nuclear Security Administration

1 paper (uncontrolled)

Nevada Site Office

Technical Library

P.O. Box 98518, M/S 505

Las Vegas, NV 89193-8518

U.S. Department of Energy

National Nuclear Security Administration

Nevada Site Office

Nuclear Testing Archive

Public Reading Facility

P.O. Box 98518, M/S 505

Las Vegas, NV 89193-8518

B. Crowe

$1 \mathrm{CD}$

U.S. Department of Energy

National Nuclear Security Administration

Nevada Site Office

Environmental Restoration Division

P.O. Box 98518, M/S 505

Las Vegas, NV 89193-8518

U.S. Department of Energy

2 CDs (uncontrolled)

Office of Scientific and Technical Information

$1 \mathrm{CD}$ (uncontrolled)

175 Oak Ridge Turnpike

Oak Ridge, TN 37831-0062

N. M. Becker

$1 \mathrm{CD}$

Los Alamos National Laboratory

P.O. Box 1663, EES-6, M/S F-665

Los Alamos, NM 87545-1663 


\section{Distribution List (continued)}

\section{$\underline{\text { Copies }}$}

E. H. Keating

$1 \mathrm{CD}$

Los Alamos National Laboratory

P.O. Box 1663, EES-6, M/S D462

Los Alamos, NM 87545-1663

E. M. Kwicklis

$1 \mathrm{CD}$

Los Alamos National Laboratory

P.O. Box 1663, EES-6, M/S T003

Los Alamos, NM 87545-1663

A. V. Wolfsberg

$1 \mathrm{CD}$

Los Alamos National Laboratory

P.O. Box 1663, EES-6, M/S T003

Los Alamos, NM 87545-1663

G. A. Pawloski

$1 \mathrm{CD}$

Lawrence Livermore National Laboratory

P. O. Box 808

Livermore, CA 94551-0808

S. Carle

$1 \mathrm{CD}$

Lawrence Livermore National Laboratory

P.O. Box 808, L-208

Livermore, CA 94550

A. Thompson

$1 \mathrm{CD}$

Lawrence Livermore National Laboratory

P.O. Box 808, L-208

Livermore, CA 94550

M. Zavarin

$1 \mathrm{CD}$

Lawrence Livermore National Laboratory

P. O. Box 808

Livermore, CA 94551-0808

C. E. Russell

$1 \mathrm{CD}$

Desert Research Institute

755 East Flamingo Road

P.O. Box 19040

Las Vegas, NV 89119-7363 


\section{Distribution List (continued)}

\section{$\underline{\text { Copies }}$}

B. K. Thompson

$1 \mathrm{CD}$

Water Resources Division, Nevada District

U.S. Geological Survey

160 N. Stephanie Street

Henderson, NV 89074

UGTA Project Manager

$1 \mathrm{CD}$

Stoller-Navarro Joint Venture

7710 West Cheyenne Ave., Building 3

Las Vegas, NV 89129

G. Ruskauff

$1 \mathrm{CD}$

Stoller-Navarro Joint Venture

7710 W. Cheyenne Ave., Building 3

Las Vegas, NV 89129

J. Wurtz

$1 \mathrm{CD}$

Stoller-Navarro Joint Venture

7710 W. Cheyenne Ave., Building 3

Las Vegas, NV 89129

Stoller-Navarro Library

$1 \mathrm{CD}$

Stoller-Navarro Joint Venture

7710 West Cheyenne Ave., Building 3

Las Vegas, NV 89129

W. Fryer

$1 \mathrm{CD}$

Stoller Corp.

990 South Public Road, Suite A

Lafayette, CO 80026

P. K. Ortego

$1 \mathrm{CD}$

National Securities Technologies, LLC.

P.O. Box 98521, MS NLV082

Las Vegas, NV 89193-8521

S. L. Drellack, Jr.

$1 \mathrm{CD}$

National Securities Technologies, LLC.

P.O. Box 98521, MS NLV082

Las Vegas, NV 89193-8521 


\section{Distribution List (continued)}

\section{$\underline{\text { Copies }}$}

M. J. Townsend

$1 \mathrm{CD}$

National Securities Technologies, LLC.

P.O. Box 98521, MS NTS416

Las Vegas, NV 89193-8521 